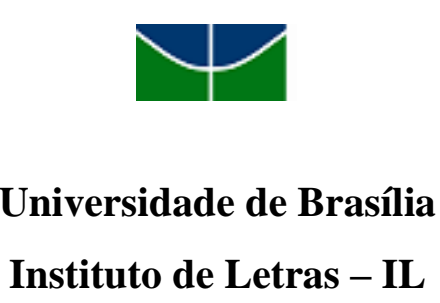

Instituto de Letras - IL

Departamento de Linguística, Português e Línguas Clássicas - LIP

Programa de Pós-Graduação em Linguística - PPGL

GÊNEROS TEXTUAIS NOS LIVROS DIDÁTICOS DE GEOGRAFIA

Fabiana Aparecida de Assis

Brasília 
Fabiana Aparecida de Assis

\section{GÊNEROS TEXTUAIS NOS LIVROS DIDÁTICOS DE GEOGRAFIA}

Dissertação apresentada ao Programa de Pós-Graduação em Linguística do Departamento de Linguística, Língua Portuguesa e Línguas Clássicas do Instituto de Letras da Universidade de Brasília, como parte dos requisitos para a obtenção do grau de Mestre em Linguística. Área de concentração: Linguagem e Sociedade.

Orientadora: Profa. Dra. Edna Cristina Muniz da Silva

\section{Brasília}




\section{GÊNEROS TEXTUAIS NOS LIVROS DIDÁTICOS DE GEOGRAFIA}

Fabiana Aparecida de Assis

Dissertação apresentada ao Programa de Pós-Graduação em Linguística do Departamento de Linguística, Língua Portuguesa e Línguas Clássicas do Instituto de Letras da Universidade de Brasília, como parte dos requisitos para a obtenção do grau de Mestre em Linguística. Área de concentração: Linguagem e Sociedade. Defendida em 24 de março de 2017.

Banca examinadora:

Profa. Dra. Edna Cristina Muniz da Silva - Orientadora e Presidente (UnB/PPGL)

Profa. Dra. Josenia Antunes Vieira - Membro efetivo interno (UnB/PPGL)

Profa. Dra. Mara Lúcia Castilho - Membro efetivo externo (Instituto Federal de Brasília-IFB)

Profa. Dra. Carmem Jená Machado Caetano - Membro suplente (UnB/PPGL) 
DEDICATÓRIA

A Deus, Senhor de minha vida.

À minha amada família. 


\section{AGRADECIMENTOS}

A Deus, em primeiro lugar, por ter permitido que eu realizasse este sonho.

Aos meus amados pais, Auxiliadora e Francisco, por serem meus exemplos e por me ensinarem a importância, especialmente, de Deus, da família e dos estudos.

A Jonio, meu amado marido, e às minhas queridas filhas, Ana Clara e Mariana, por acreditarem nos meus sonhos, por me incentivarem e por me darem o apoio necessário para realizá-los. Por me alegrarem e por compreenderem minha ausência.

Aos meus queridos irmãos, Patrícia e Weber, pelo carinho, pelos conselhos, pelos doces encontros.

A minha cunhada Andrezza, pelas conversas, pelas trocas, por sua curiosidade que me estimula.

Aos meus sobrinhos, Beatriz e Davi, pela alegria e inocência, que alimentam minha alma.

Ao meu sobrinho Lucas, pelas enriquecedoras conversas e por suas contribuições, especialmente, nas traduções.

Aos meus sogros, Iracema e José Antônio, por compreenderem minhas ausências durante esses dois anos.

À tia Graciema, por seus preciosos conselhos.

À pequena Luna, minha fiel companheira nas intermináveis horas de tradução, leitura e escrita.

À minha orientadora, Profa. Dra. Edna Cristina Muniz da Silva, por compartilhar seus conhecimentos, por sua sensibilidade, por sua simplicidade, por sua compreensão, por sua amizade.

À amiga Denise Fukuda, pela amizade e pela disposição em ajudar sempre.

À amiga Kelly Cristina, pelos conselhos, pela constante motivação, por fazer de minhas preocupações as suas, pela amizade.

Aos meus amigos de orientação, Alessandro, Danúzia, Gláucia, Rosana, pelas inestimáveis contribuições durante as aulas e nos animados encontros.

A todos os meus amigos, que, de algum modo me incentivaram e me motivaram nesta desgastante, mas incrível jornada.

À Professora Dr.a Josênia Vieira, pelas aulas de Letramentos e Práticas sociais que permitiram a expansão da minha pesquisa rumo à multimodalidade, e pelas ricas contribuições na minha qualificação. 
Às Professoras Dr.as Carmem Jená, Janaína Ferraz, e Maria Luiza Coroa, pelas aulas que ministraram e pelos seminários e artigos que solicitaram, determinantes para a construção desta pesquisa.

À Secretaria de Educação do Distrito Federal, por ter concedido o afastamento para que eu me dedicasse a este projeto.

Ao Diretor do Centro de Ensino Fundamental 35, meu chefe, Marcelo Fernandes, que sempre acreditou no meu trabalho e me incentivou a estudar e participar dos eventos acadêmicos.

À Ângela Souza, um anjo no PPGL.

Às Professoras Dr.as Sara Cabral, Cristiane Fuzer, Francieli Matzembacher Pinton e ao Prof. Dr. Orlando Vian Jr. pelas contribuições compartilhadas nos eventos do SAL.

À Profa Dra. Leila Bárbara, por unir anualmente diversos pesquisadores no SAL.

À Sandra Campêlo, colega e especialista em ABNT, que me auxiliou em um momento decisivo.

Aos meus colegas de disciplinas, aos meus colegas de trabalho e aos meus alunos, por contribuírem, de um jeito ou de outro, com minhas reflexões. 
“Antes mundo era pequeno

Porque Terra era grande

Hoje mundo é muito grande

Porque Terra é pequena

Do tamanho da antena parabolicamará

$\hat{E}$, volta do mundo, camará

$\hat{E}, \hat{e}$, mundo dá volta, camará

Antes longe era distante

Perto, só quando dava

Quando muito, ali defronte

E o horizonte acabava

[...]"(Gilberto Gil) 


\section{RESUMO}

Com o objetivo de analisar os textos presentes em um capítulo de cada um dos três livros de Geografia mais adotados para os alunos do $9^{\circ}$ ano do ensino fundamental, no Programa Nacional do Livro Didático (PNLD 2014), a fim de identificar os gêneros presentes nesses capítulos, bem como as características léxico-gramaticais, este estudo é orientado pelos arcabouços teórico-metodológicos da Teoria de Gêneros da Escola de Sydney (EGGINS e MARTIN 1994; MARTIN e ROSE 2008; 2012) e da Gramática Sistêmico Funcional (HALLIDAY, 1978, 1994; HALLIDAY e MATTHIESSEN, 2004, 2014; BUTT et al). E para descrição e análise da linguagem visual, orienta-se pela Teoria Semiótica Social da Multimodalidade (KRESS e VAN LEEUWEN,2006; UNSWORTH, 2006). A seleção do corpora é temática, tendo o macro tema Globalização como recorte, devido à relevância dos temas para a compreensão dos desafios atuais da humanidade. Após leitura, descrição e análise de textos verbais para a identificação de como os eventos são representados Metafunção ideacional -, das relações estabelecidas entre autor e leitor - Metafunção Interpessoal -, e dos modos como as informações sobre os eventos e as relações foram organizadas nos textos - Metafunção Textual -, pode-se verificar a predominância de relações causais entre as informações, evidenciando explicações sequenciais, quando um evento desencadeia outro, que desencadeia outro e assim sucessivamente; explicações fatoriais, quando vários fatores culminam em um evento; e explicações consequenciais, quando um evento desencadeia várias consequências. Esses gêneros, de acordo com a classificação elaborada por pesquisadores da Escola de Sydney, pertencem à família das Explicações. Em relação aos recursos visuais, foram encontrados principalmente mapas e fotografias narrativas que estabelecem relação de complementariedade por acréscimo com os textos verbais.

Palavras-chave: Gêneros Textuais. Gramática Sistêmico Funcional. Explicações. Linguagem Visual. 


\begin{abstract}
With the objective of analyzing the present texts found in chapters of each one of the three most adopted geography books for the ninth grade of the brazilian middle school, in the Programa Nacional do Livro Didático (PNLD 2014), in order to identify the given genres in these chapters, as well as the lexical-grammatical characteristics, this study is guided by the theoretical-methodological frameworks of the Theory of Genres from Sydney School (EGGINS e MARTIN 1994; MARTIN e ROSE 2008; 2012) and from the Systemic Functional Grammar. And for the description and analysis of the visual language, it is oriented by the Social Semiotic Theory of Multimodality (Kress e van Leeuwen,2006; Unsworth, 2006). The selection of the corpora is thematic, having the macro theme Globalization as a cut, due to the relevance of the themes for the comprehension of the current humanity challenges. After lecture, description and verbal text analysis for the identification of how the events are represented - Ideational Metafunction -, from the established relations between author and reader - Interpersonal Metafunction -, and the modes on how the information and relations about the events are organized on the texts - Textual Metafunction , the predominance of causal relations between the information can be verified, evidencing factorial explanations, when several factors culminate in an event, and consequential explanations, when an event triggers several consequences. These genres, according to the classification developed by the researchers from Sydney School, belongs to the explanation family. In relation to the visual resources, maps and narrative photographs were mainly found to establish a complementary relation with the addition with the verbal texts.
\end{abstract}

Keywords: Textual Genres. Systemic Functional Grammar. Explanations. Visual Language. 


\section{LISTA DE ILUSTRAÇÕES}

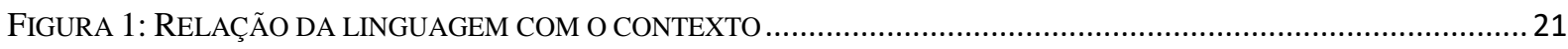

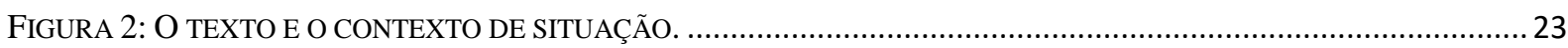

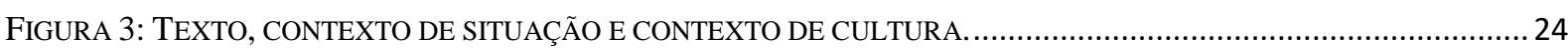

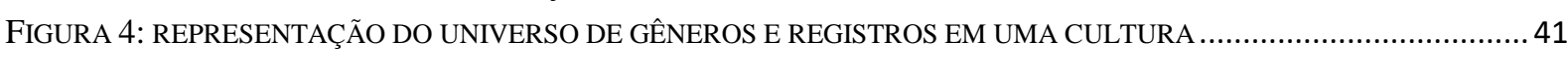

FigURA 5: IMAGEM E LEGENDA PRESENTES EM LIVRO PROJETO TELÁRIS. ....................................................... 53

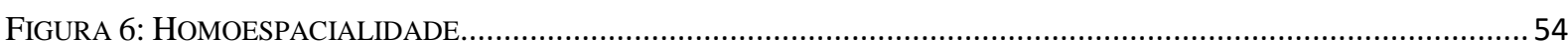

FIGURA 7: RELAÇÕES ENTRE OS MODOS.

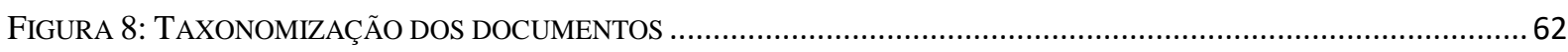

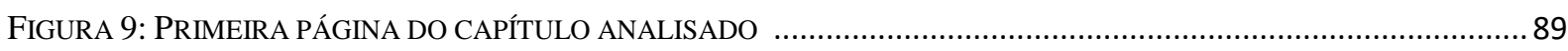

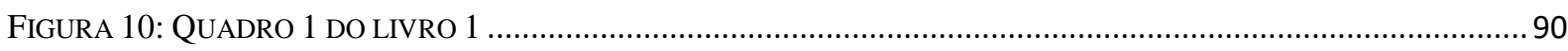

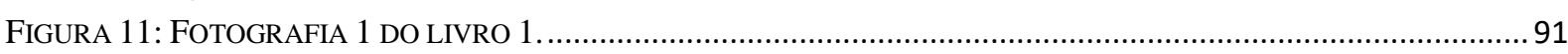

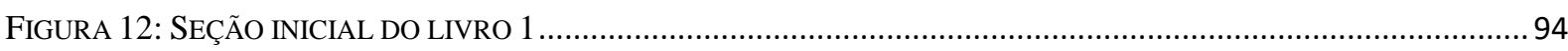

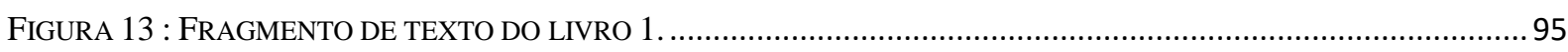

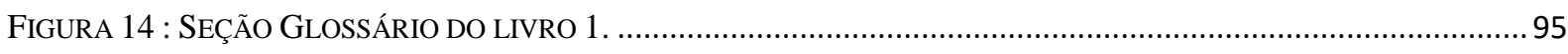

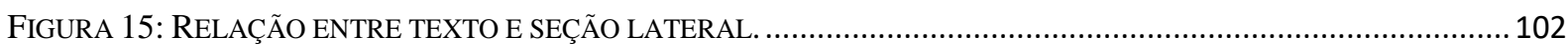

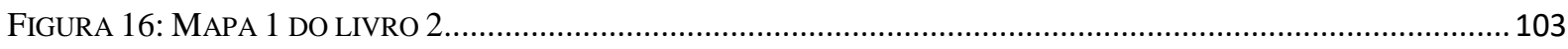

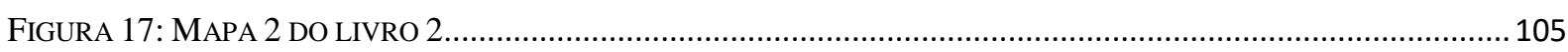

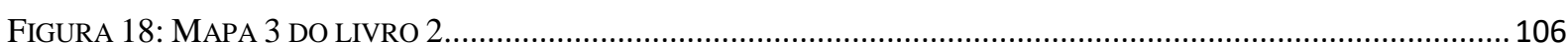

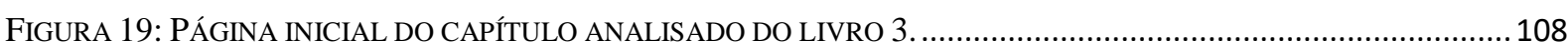

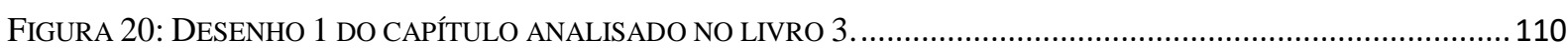

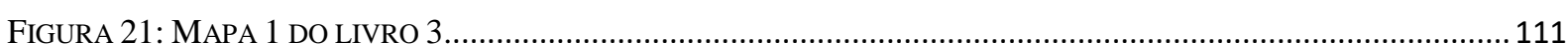

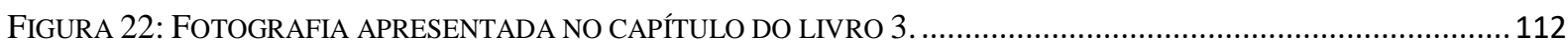

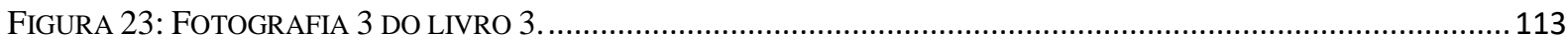

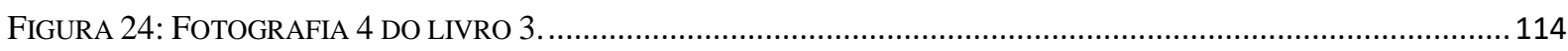

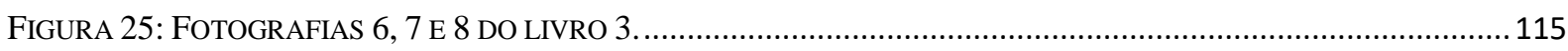

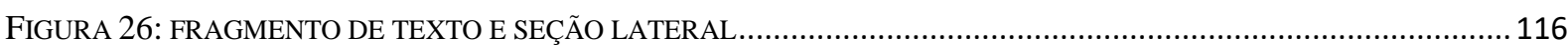

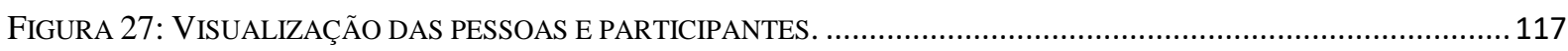

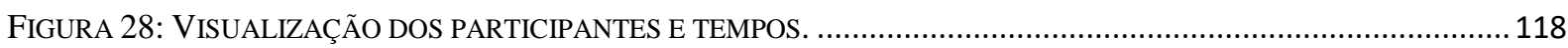

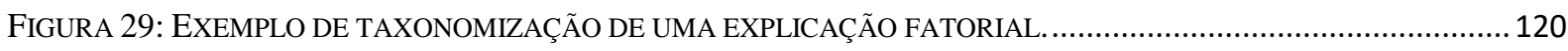

FIGURA 30: EXEMPLO DE TAXONOMIZAÇÃO DE UMA EXPLICAÇÃO CONSEQUENCIAL ........................................... 120

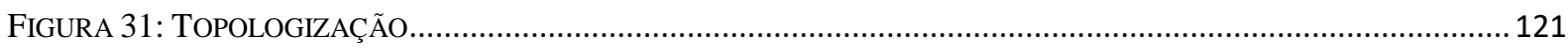




\section{LISTA DE QUADROS}

QuADRO 1: RELAÇõES ENTRE VARIÁVEIS DE CONTEXTo DE SituAÇÃO, METAFUnÇÕES E

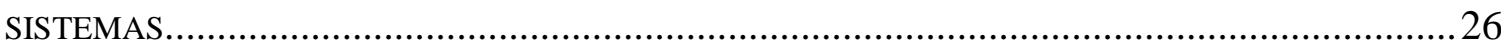

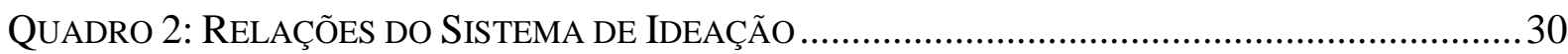

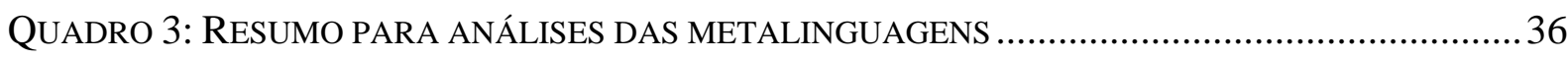

QUAdRO 4: CLASSIFICAÇÃO dOS GÊNEROS ESCOLARES PARA A ESCOLA DE SYDNEY. ............... 43

QuAdro 5: RESUMO DA CONSTITUIÇÃO DO CAPÍTUlO ANALISADO - PROJETO TELÁRIS ..........65

QuADRO 6: RESUMO DA CONSTITUIÇÃO DO CAPÍTULO ANALISADO - EXPEDIÇÕES

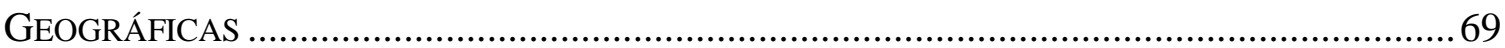

QuAdro 7: RESUMO DA CONSTITUIÇÃO DO CAPÍTUlO ANALISADO - PROJETO ARARIBÁ ......... 71

QUADRO 8: RELAÇÃO ENTRE FIGURA 2, LEGENDA E TEXTO PRINCIPAL ....................................97

QUADRO 9: RELAÇÃO ENTRE AS FIGURAS 3, 4, 5 E 6 E RESPECTIVAS LEGENDAS........................98

QUADRO 10: SEÇÕES COMPLEMENTARES DO LIVRO EXPEDIÇÕES GEOGRÁFICAS. .....................101

QUADRO 11: INFORMAÇÕES EM CADA MODO DO CAPÍTULO NO LIVRO 2 . ................................. 104

QUADRO 12: INFORMAÇÕES SOBRE O OBJETO EDUCACIONAL DIGITAL 7 ................................ 109

QUADRO 13: FATORES DETERMINANTES PARA UM EVENTO................................................ 119

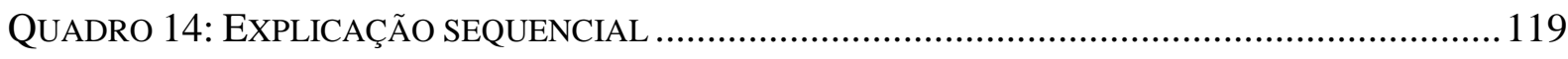

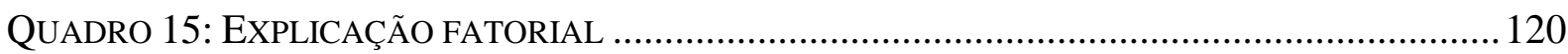

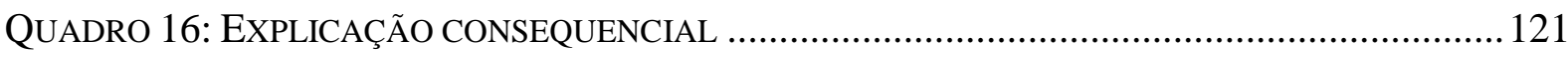




\section{LISTA DE SIGLAS E ABREVIATURAS}

DIT - Divisão Internacional do Trabalho

FNDE - Fundo Nacional de Desenvolvimento da Educação

GDV - Gramática do Design Visual

GSF - Gramática Sistêmico Funcional

IBGE - Instituto Brasileiro de Geografia e Estatística

PCNs - Parâmetros Curriculares Nacionais

PIB - Produto Interno Bruto

PNLD - Programa Nacional do Livro Didático

PUC - Pontifícia Universidade Católica

SAL - Systemic Across Languages

$T G R$ - Teoria de Gêneros e Registros

TSSM - Teoria Semiótica Social da Multimodalidade

VOLP - Vocabulário Ortográfico da Língua Portuguesa 


\section{Sumário}

INTRODUÇÃ̃ ................................................................................................................... 14

CAPÍTULO 1 - REFERENCIAL TEÓRICO.............................................................................. 21

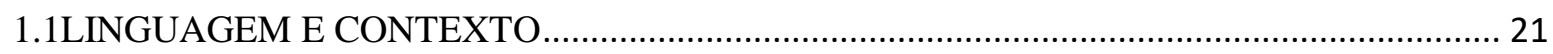

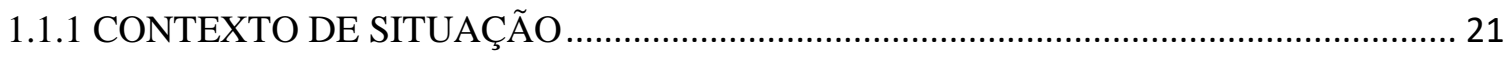

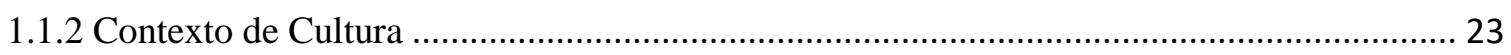

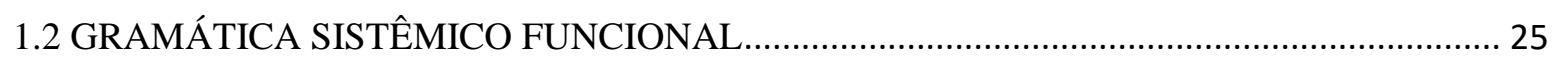

1.2.1 Níveis de Análise ………………………………………………………………... 25

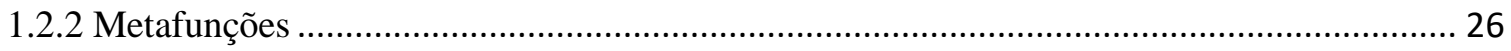

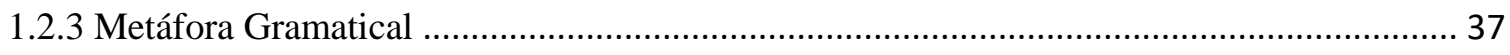

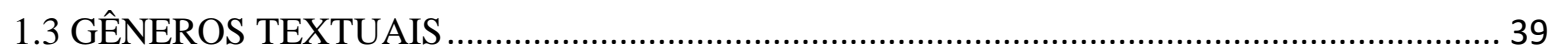

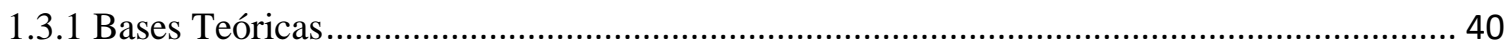

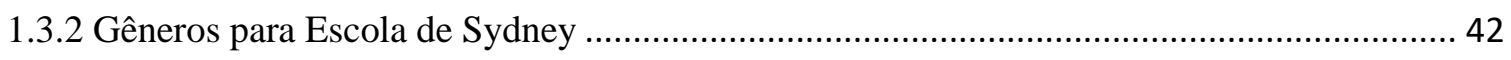

1.3.3Gêneros do Contexto Escolar ............................................................................................. 43

1.4 TEORIA SEMIÓTICA SOCIAL DA MULTIMODALIDADE ................................................ 47

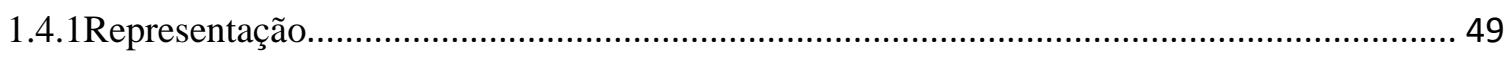

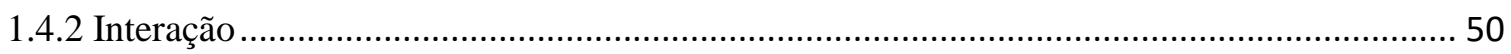

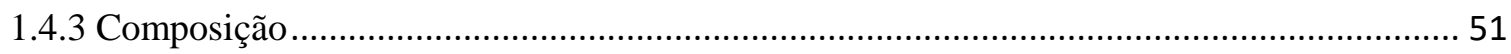

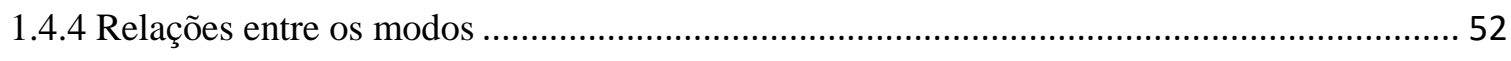

CAPÍTULO 2 - CAPÍTULO METODOLÓGICO ..................................................................... 57

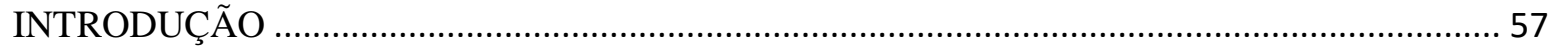

2.1 DELINEAMENTO METODOLÓGICO ……………………………………………… 57

2.2 PESQUISA SOCIAL …………………………………………………………. 57

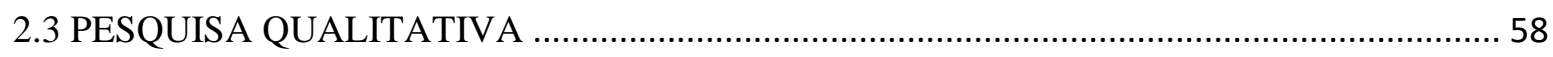

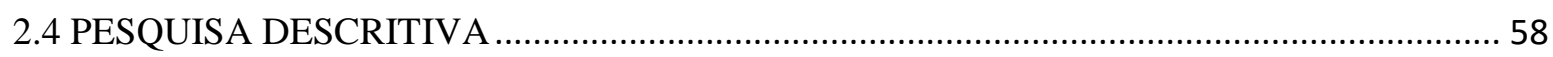

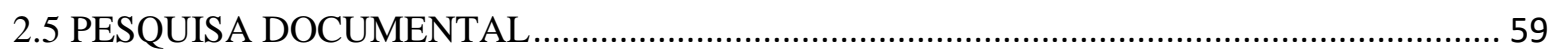

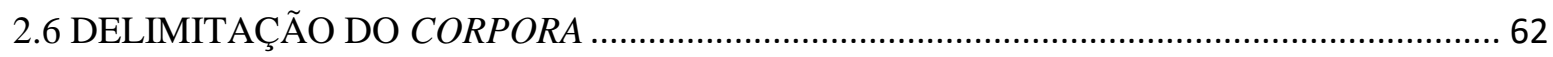

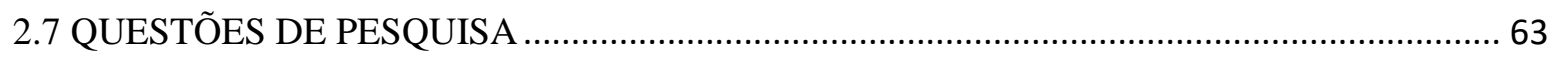

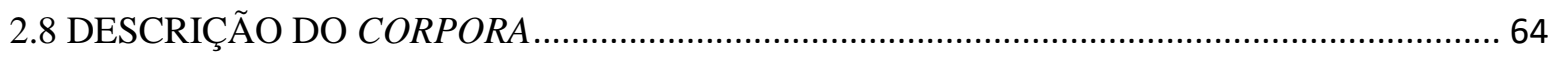

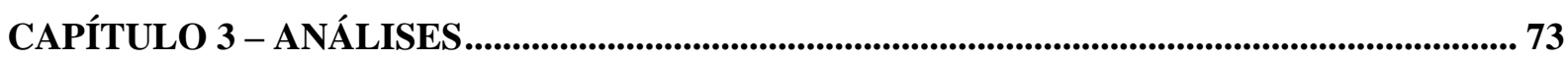

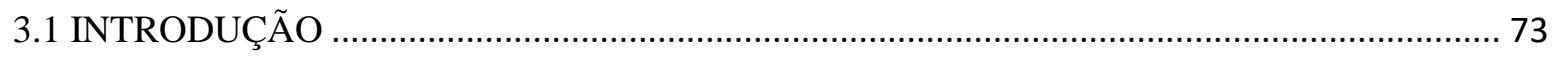




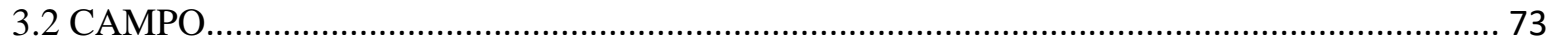

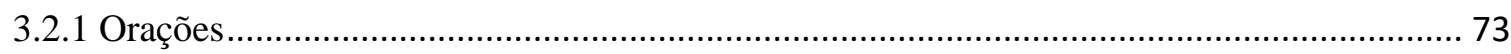

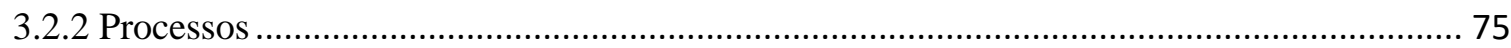

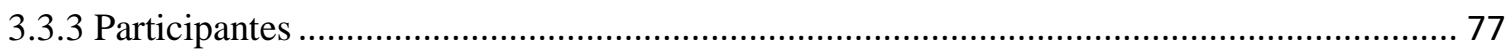

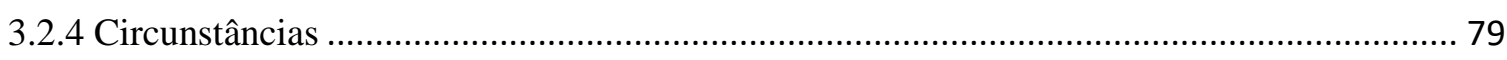

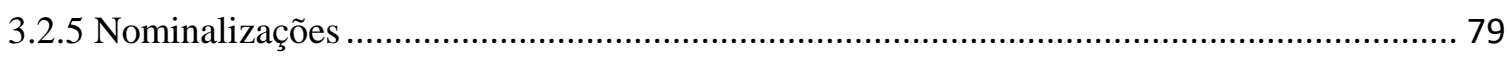

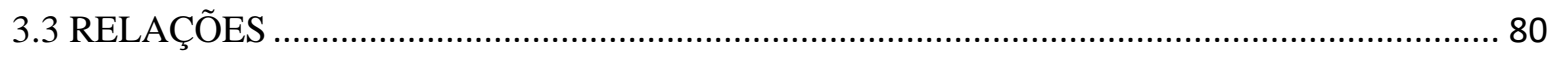

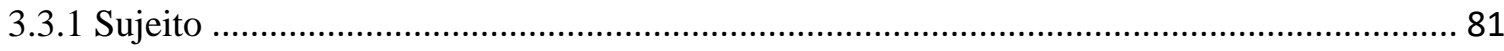

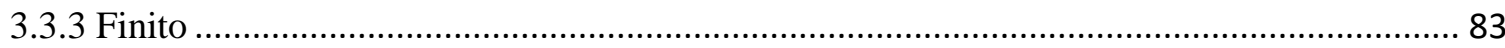

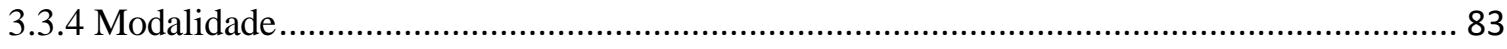

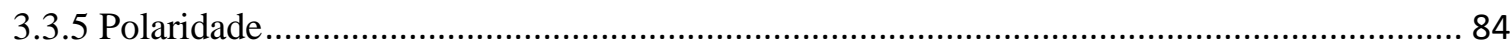

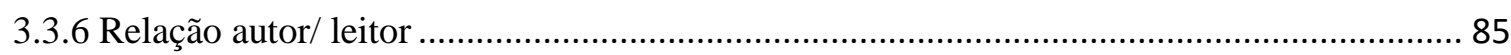

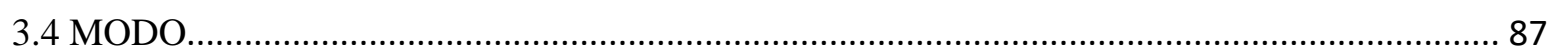

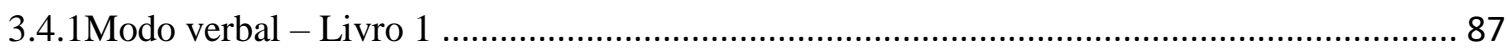

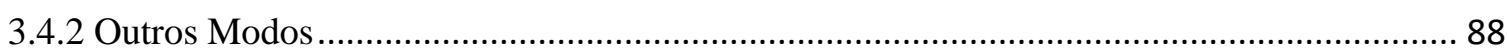

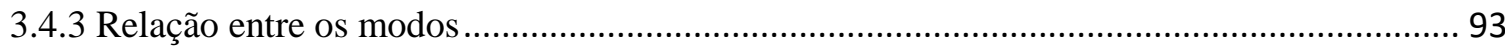

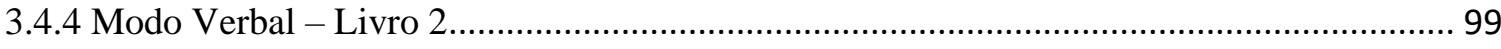

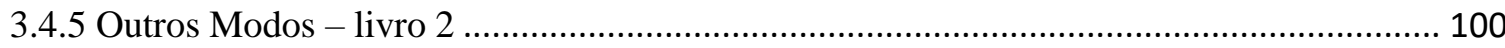

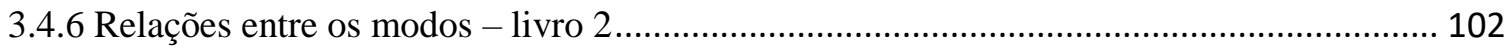

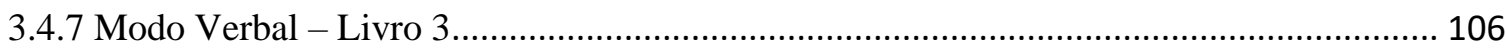

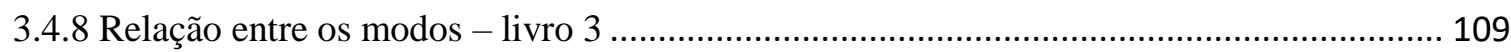

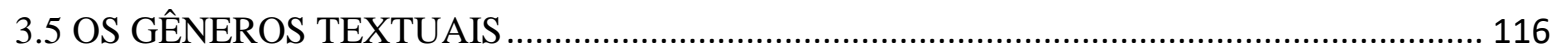

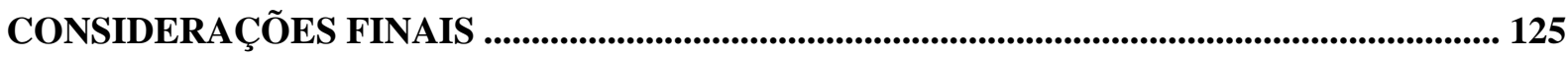

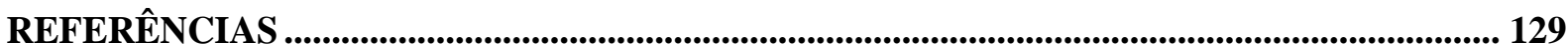




\section{INTRODUÇÃO}

Esta pesquisa é resultado de um estudo acerca de gêneros textuais sob a perspectiva da Gramática Sistêmico Funcional e está vinculado a estudos desenvolvidos pela Prof.a D.ra Edna Cristina Muniz da Silva dentro da linha de pesquisa sobre Discursos, Representações sociais e Textos do Programa de Pós-graduação em Linguística da Universidade de Brasília (UnB) e aos trabalhos desenvolvidos pelo grupo brasileiro do Projeto Systemics Across Languages (SAL), que estuda as contribuições da Gramática Sistêmico Funcional para o ensino de línguas e para a Análise de Discurso, e é coordenado pela Prof. ${ }^{a}$ D.ra Leila Barbara, da Pontifícia Universidade Católica de São Paulo (PUCSP).

Os estudos sobre gêneros textuais desenvolvidos no Brasil e em outros países (África do Sul, Quênia, Uganda, Tanzânia, Suécia, Finlândia, Reino Unido, Espanha, Portugal, EUA, Chile, Hong Kong e na Austrália), sob a perspectiva da Gramática Sistêmico Funcional, buscam investigar de que forma essa abordagem pode contribuir para que a aprendizagem de leitura e de escrita seja mais eficaz para os alunos, pois, segundo Halliday e Hasan (1989), pode-se trabalhar com gêneros diversos, na sala de aula, com três objetivos: aprendizagem e/ou ampliação do repertório dos gêneros dos estudantes; ensino e conscientização dos gêneros e ensino por meio dos gêneros.

Historicamente, a educação passa por transformações conforme as demandas da sociedade. E, desde a publicação da Lei de Diretrizes e Bases da Educação Básica (LDB), em 1996, e dos Parâmetros Curriculares Nacionais (referências nacionais básicas dos conteúdos a serem desenvolvidos nas cinco regiões brasileiras), em 1998, houve muitas mudanças na educação brasileira, entre elas a orientação para o ensino da leitura e da escrita fundamentado nos gêneros textuais por diversos motivos, entre eles,

Formar escritores competentes, supõe, portanto, uma prática continuada de produção de textos na sala de aula, situações de produção de uma grande variedade de textos de fato e uma aproximação das condições de produção às circunstâncias nas quais se produzem esses textos. Diferentes objetivos exigem diferentes gêneros e estes, por sua vez, têm suas formas caraterísticas que precisam ser aprendidas. (PARÂMETROS CURRICULARES NACIONAIS DE LÍNGUA PORTUGUESA, 1998, p. 49) 
É certo que o ensino de gêneros textuais orientado pelos Parâmetros Curriculares Nacionais (PCNs) tem suas bases teóricas nos estudos russo Mikhail Bakhtin ${ }^{1}$, e esta pesquisa foi estruturada com base na Teoria de Gêneros da Escola de Sydney. Entretanto, independente da abordagem teórica, o fato é que a aprendizagem dos e por gêneros pode ser bem mais eficiente para os estudantes, visto que pode prepará-los melhor para diversas situações de uso da leitura, da fala e da escrita, conforme afirmado nos PCNs

[...] é necessário contemplar, nas atividades de ensino, a diversidade de textos e gêneros, e não apenas em função de sua relevância social, mas também pelo fato de que textos pertencentes a diferentes gêneros são organizados de diferentes formas. A compreensão oral e escrita, bem como a produção oral e escrita de textos pertencentes a diversos gêneros, supõem o desenvolvimento de diversas capacidades que devem ser enfocadas nas situações de ensino. É preciso abandonar a crença na existência de um gênero prototípico que permitiria ensinar todos os gêneros em circulação social (PARÂMETROS CURRICULARES NACIONAIS, 1998, p. 23-24).

Um dos problemas relacionados ao ensino dos gêneros textuais e dos conteúdos por meio deles reside no fato de que, quando ocorre, tem ficado sob a responsabilidade do professor de Língua Portuguesa. Apesar de cada área, cada ciência ter suas especificidades e operar com conceitos, categorias e procedimentos cujos significados se realizam por meio de gêneros textuais e de gêneros multimodais diferentes, para atingir os propósitos sociais de envolver, informar e avaliar.

A Geografia, por exemplo, é uma disciplina relevante para que o aluno compreenda a importância do espaço geográfico. E esse era o principal objetivo do ensino dessa ciência quando foi introduzida no currículo escolar, conforme Oliveira et al (2014)

O peso da descrição física na geografia escolar foi sempre importante. Esta importância quantitativa não é absolutamente proporcional ao lugar qualitativo que os fatores físicos têm no raciocínio (ou arremedo de raciocínio) do curso de geografia. Esta distorção é devida, sem dúvida, ao fato de que a geografia foi concebida inicialmente como auxiliar da história no quadro do ensino.

[...] A geografia é antes de tudo a disciplina que permite, pela descrição, conhecer os lugares onde os acontecimentos se passaram. Esta situação subordinada da geografia à história foi reforçada pela preocupação patriótica. O objetivo não é de raciocinar sobre um

\footnotetext{
${ }^{1}$ De acordo com a perspectiva bakhtiniana, os gêneros são "determinados historicamente, constituindo formas relativamente estáveis de enunciados, disponíveis na cultura. São caracterizados por três elementos: • conteúdo temático: o que é ou pode tornar-se dizível por meio do gênero; • construção composicional: estrutura particular dos textos pertencentes ao gênero; - estilo: configurações específicas das unidades de linguagem derivadas, sobretudo, da posição enunciativa do locutor; conjuntos particulares de sequiências3 que compõem o texto etc.”(PARÂMETROS CURRICULARES NACIONAIS, 1998, p. 21)
} 
espaço, mas de fazer dele um inventário, para delimitar o espaço nacional e situar o cidadão neste quadro. (OLIVEIRA et al, 2014, p. 17)

Contudo, há algumas décadas, o ensino dessa disciplina vem passando por modificações, deixando de tratar de aspectos puramente físicos, para tratar do espaço sob uma vertente mais crítica. Assim, temas atuais são tratados com base em uma perspectiva em que não só os espaços dos eventos são importantes, mas também os eventos, os participantes envolvidos, as causas e as consequências ocupam lugar de destaque, objetivando com isso, que o aluno compreenda a importância de todos esses elementos para a sociedade na qual está inserido, e também, que ele compreenda as relações sociais, econômicas e culturais estabelecidas entre habitantes de uma nação e entre habitantes de nações diferentes e os desdobramentos dessas interações.

Um dos temas que permite o estudo de todas essas relações é a globalização, pois envolve muitas transformações em pouco tempo. A globalização está relacionada a alterações nas relações econômicas, trabalhistas e culturais. Também está relacionada ao desenvolvimento tecnológico e dos transportes, que modificaram as percepções temporais e espaciais e as relações comercias e turísticas.

Relações comerciais entre nações existem há séculos, contudo, por volta de quatro décadas foi constatado, por estudiosos de diversas ciências, que as relações comerciais passaram a ser definidas em função do capitalismo, pois o que se tornou determinante para as empresas em expansão foi a produção com menor custo. Assim, muitas empresas americanas e europeias deixaram de produzir em seus países, para produzir em lugares como China, Índia, Bangladesh, Taiwan, Vietnam, onde os custos, especialmente com mão de obra, são bem mais baratos. Como consequências houve o desemprego nos países cujas empresas migraram a produção; e, para os lugares que receberam indústrias, não há certezas sobre a fixação dessas empresas, pois, conforme afirma Bauman

No mundo pós-guerra espacial, a mobilidade tornou-se o fator de estratificação mais poderoso e mais cobiçado, a matéria de que são feitas e refeitas diariamente as novas hierarquias sociais, políticas econômicas e culturais em escala cada vez mais mundial. (BAUMAN, 1998, p. 16)

Como Bauman salienta, as empresas transnacionais aproveitam as localidades para produzirem com custos menores, usam os incentivos dos Estados, a mão de obra, os fornecedores e transportes locais, porém, quando decidem migrar para outra localidade, 
motivados por outros atrativos e pelo capital móvel, livram-se das responsabilidades com todos os elementos humanos envolvidos nessa cadeia de produção, desencadeando problemas econômicos, sociais e ambientais.

Outro fator que transformou as relações foi a rede mundial de computadores, pois ela conecta pessoas do mundo por trabalho, por lazer, por estudo, por turismo; e, como a troca de informações é instantânea, isso faz com a noção de tempo pareça alterada. Todavia, as tecnologias não estão disponíveis para todos, logo, há uma infinidade de pessoas pelo mundo não incluídas digitalmente, isto é, à margem do desenvolvimento.

O turismo também foi modificado por conta das melhorias nos transportes. Por exemplo, diariamente milhares de voos levam turistas de diversos lugares para outros. Porém, não se trata de um evento possível para todos, pois ainda que seja mais rápido e mais barato do que era há algumas décadas, viajar não é uma atividade acessível para uma grande parcela da sociedade mundial.

Problemas ambientais desencadeados por mudanças nos processos de produção, por exploração desordenada de bens naturais e por alterações das paisagens naturais para adaptação dos espaços para turistas, instalação de empresas e assentamento ou expansão de cidades estão na pauta de organismos internacionais e exigem uma mudança de postura de todos, visto que os recursos naturais são esgotáveis e o desequilíbrio no uso descontrolado deles tem provocado mudanças climáticas.

Por exemplo, de acordo com relatório da ONU, publicado em 2016, sobre o uso da água, na América Latina, encontra-se um terço da água doce do mundo; contudo, como é utilizada excessivamente em atividades econômicas como agricultura, exploração de minérios e produção industrial, a região está vulnerável ambiental, social e economicamente, pois, se há escassez ou esgotamento de água, isso representa problemas para o meio ambiente, para as populações e, sem um recurso natural determinante para a manutenção dessas atividades econômicas, o aumento do desemprego é certo.

Mudanças comerciais, temporais, espaciais e tecnológicas têm provocado mudanças culturais pelo mundo, porque, as informações circulam rapidamente, inclusive sobre tendências de comportamento, de consumo e de moda. E, segundo van Leeuwen (2005, p. $40)$, "as pessoas usam a forma como se vestem para comunicarem sua fidelidade a ideias e valores, ao invés de sua classe social, ocupação, e assim por diante." Porém, esses novos 
comportamentos muitas vezes são determinados pelos importadores, que, van Leeuwen (2005) explica

Esse tipo de 'importação' é uma característica essencial da paisagem semiótica da era da cultura global. Os designers de moda, por exemplo, constantemente importam ideias de outros períodos, outras culturas, trajes de ficção científica em filmes, etc., para conotar as ideias e valores ligados a esses períodos, culturas e assim por diante na cultura popular e para prover pessoas com recursos para significar sua fidelidade a ideias, valores, estilos de vida e assim por diante. Alguns domínios nem sequer têm sua própria forma de expressão. Música publicitária, por exemplo, vai abraçar qualquer estilo de música, desde que atraia o público-alvo. (VAN LEEUWEN, 2005, p. 41)

Logo, os problemas da universalização da cultura são que os costumes e hábitos locais vão sendo adaptados para dar lugar aos costumes globais, favorecendo a perda das identidades culturais de cada povo. E, nessa eleição dos hábitos e costumes que devem ser globalizados, quase sempre os países menos desenvolvidos são mais afetados, pois normalmente copiam comportamentos e hábitos, e raramente inspiram.

A globalização é consequência de grandes acontecimentos de um passado mais remoto e é a causa de diversos desdobramentos, em um passado mais recente e no presente, que afetam a população mundial. Então, analisar os textos dos livros didáticos que tratam sobre esse complexo acontecimento é tentar compreender como eventos, participantes e relações são representados nos gêneros do contexto escolar.

Portanto, com base nessas reflexões e em outras que surgiram com leituras, estudos e debates do grupo de pesquisa coordenado pela Prof. ${ }^{a}$ Edna Cristina Muniz, no âmbito do Programa de Pós-Graduação em Linguística da Universidade de Brasília, linha de pesquisa sobre Discursos, Representações sociais e Textos, elaborei as seguintes questões de pesquisa:

1. Quais os gêneros presentes nos livros didáticos de Geografia?

2. Quais os propósitos sociais dos gêneros presentes nos livros didáticos de Geografia?

3. Como as características léxico-gramaticais são organizadas para representação dos eventos e das relações?

4. Quantos modos semióticos, além do verbal, compõem o livro didático de Geografia?

5. Como a relação entre os modos semióticos constroem os significados?

\section{Objetivo Geral}


1. Identificar os gêneros textuais e multimodais presentes nos livros didáticos de Geografia.

\section{Objetivos específicos}

1.1 Identificar, com base no referencial teórico-metodológico da abordagem sobre gêneros da Escola de Sydney, os propósitos sociais dos textos.

1.2 Descrever as características linguísticas dos textos com base nas metafunções experiencial, interpessoal e textual, para determinação dos gêneros.

1.3 Descrever os outros modos semióticos presentes nos textos.

1.4 Identificar as relações estabelecidas pela união de dois modos semióticos.

Para o desenvolvimento desta pesquisa baseio-me na

1. Gramática Sistêmico Funcional (Halliday,1994; Halliday e Matthiessen, 2004, 2014; Butt et al);

2. Teoria de Gêneros da Escola de Sydney (Eggins e Martin, 1994; Martin e Rose, 2007, 2008 ; 2012) e

3. Teoria Semiótica Social da Multimodalidade (Kress e van Leeuwe, 2006; Unsworth, 2006).

A utilização dessas teorias se justifica porque todas compartilham a ideia de que a linguagem carrega três significados: o de representação do mundo físico e do mundo da consciência; o de representação das relações entre os participantes do texto e das relações entre escritor/leitor, ou falante/ ouvinte, ou ilustrador, fotógrafo/apreciador. E o de que a linguagem serve para organizar os significados acerca dos eventos e das relações. Também, todas as teorias têm como fundamento o princípio de que o se texto encontra inserido em dois contextos: o de situação, que determina o registro por meio das variáveis campo, relações e modo; e o de cultura, que determina o gênero que será utilizado.

Esta dissertação foi organizada em quatro capítulos. No Capítulo I, o referencial teórico, que serve como base para as descrições e análises do corpora é apresentado. Então conceitos importantes como de linguagem, de contexto de situação e de contexto de cultura, e as teorias utilizadas para análise dos dados desta pesquisa estão presentes. No Capítulo II, há a explicação de como a pesquisa foi desenhada e de como os dados foram coletados e 
descritos. No Capítulo III, são apresentadas as análises com base nas teorias da Gramática Sistêmico Funcional, da Teoria de Gêneros da Escola de Sydney e da Teoria Semiótica Social da Multimodalidade. E no capítulo IV são apresentadas as considerações finais, que revelam os resultados encontrados e destacam a importância de algumas ações no contexto educacional brasileiro. 


\section{CAPÍTULO 1 - REFERENCIAL TEÓRICO}

\subsection{LINGUAGEM E CONTEXTO}

Na perspectiva de Halliday, a linguagem é utilizada para representar acontecimentos, para representar relações e para organizar informações. Então, a linguagem é flexível, moldável por diversos motivos como: a cultura na qual o falante/escritor/ilustrador está inserido, a idade dele, o nível de escolaridade; a modalidade da língua usada - falada, escrita, ilustrada, multimodal - para a construção do texto; o nível de conhecimento sobre o tema que, tanto o falante/escritor/ilustrador e o ouvinte/leitor têm, entre outros fatores. Logo, o trabalho dos sistêmicos funcionais consiste em realizar estudos acerca da compreensão dos elementos linguísticos e dos elementos extralinguísticos que envolvem a tessitura de um texto a fim de descrevê-los, analisá-los e encontrar padrões para compreender as estruturas.

Os elementos que contribuem para que a linguagem seja utilizada de formas distintas entrelaçam-se constituindo o contexto social, que estabelece uma relação de mão dupla com a linguagem, pois, de acordo com Eggins e Martin (1994, p.340), as características linguísticas codificam as dimensões culturais, logo, quando se lê um texto, pode-se decodificá-lo e inferir as características do contexto.

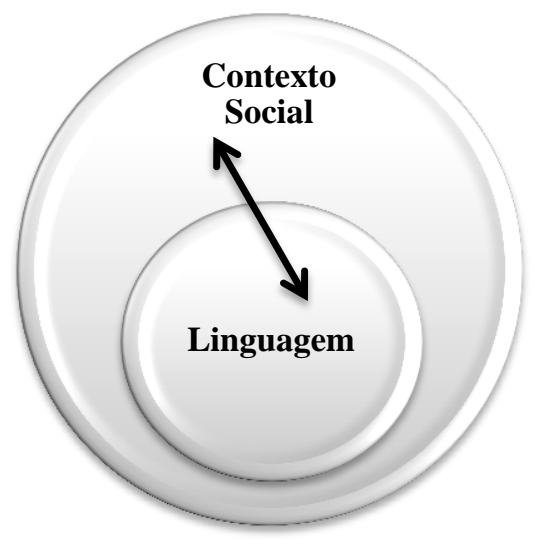

Figura 1: Relação da linguagem com o contexto

Fonte: Eggins e Martin (1994, p. 340)

\subsubsection{CONTEXTO DE SITUAÇÃO}

O antropólogo Malinowsky, em suas pesquisas de campo para investigar povos das ilhas do Pacífico, observou que a compreensão de hábitos, de costumes, de leis, de tradições e de crenças é fundamental para a o entendimento de que o modo de agir das pessoas, as suas relações são determinadas pela situação e pela cultura em que estão inseridas. 
Em certos tipos de pesquisa científica - especialmente o que se costuma chamar de "levantamento de dados", ou survey - é possível apresentar, por assim dizer, um excelente esqueleto da constituição tribal, mas ao qual faltam carne e sangue. Aprendemos muito a respeito da estrutura social nativa mas não conseguimos perceber ou imaginar a realidade da vida humana, o fluxo regular dos acontecimentos cotidianos, as ocasionais demonstrações de excitação em relação a uma festa, cerimônia ou fato particular. Ao desvendar as regras e regularidades dos costumes nativos, e ao obter do conjunto de fatos e de asserções nativas uma fórmula exata que os traduza, verificamos que esta própria precisão é estranha à vida real, a qual jamais adere rigidamente a nenhuma regra. Os princípios precisam ser suplementados por dados referentes ao modo como um determinado costume é seguido, ao comportamento dos nativos na obediência às regras que o etnógrafo formulou com tanta precisão e às próprias exceções tão comuns nos fenômenos sociológicos. (MALINOWSKI, 1978, p. 27-29)

Assim, considerou que um estudo sobre um aspecto ou outro acerca dos elementos humanos pertencentes às etnias pesquisadas não era suficiente para a compreensão de determinado agir. Antes, havia a necessidade de compreender o todo para explicar as partes.

Com base nas investigações de Malinowski sobre os significados no contexto, pesquisadores, como antropólogos, sociólogos e linguistas passaram a considerar a relevância dos contextos em seus estudos, entre eles, Halliday, que estabeleceu conexão entre a teoria linguística que desenvolvia com os dados sobre contexto de Malinowski, por acreditar que o uso da linguagem depende da situação em que o falante/escritor está envolvido.

As variáveis de contexto de situação são três: campo, relações e modo. A primeira está relacionada àquilo que é falado ou escrito sobre um determinado evento. A segunda se refere às relações que são estabelecidas entre os participantes representados no texto e às relações entre falante/ouvinte ou escritor/leitor. A terceira variável está relacionada ao modo como as informações são organizadas para a construção do texto, independente de ser falado ou escrito, e independente da extensão do texto.

Em uma representação gráfica, o contexto de situação é aquele representado imediatamente ao redor do texto, porque está diretamente relacionado às condições em que o texto é produzido. E ao elaborar questionamentos como: Qual o assunto do texto? Quem é o escritor/falante? Qual o nível de conhecimento que o produtor do texto tem sobre o assunto? E o leitor/ ouvinte? Para quem foi produzido o texto? Como o texto foi construído? Qual (is) o (s) modo(s) utilizado (s) para o que o texto fosse tecido? buscam-se as respostas para aquilo 
que determinam as diferenças de registro em um texto: as variáveis de campo (o quê), relações (quem) e modo (como).

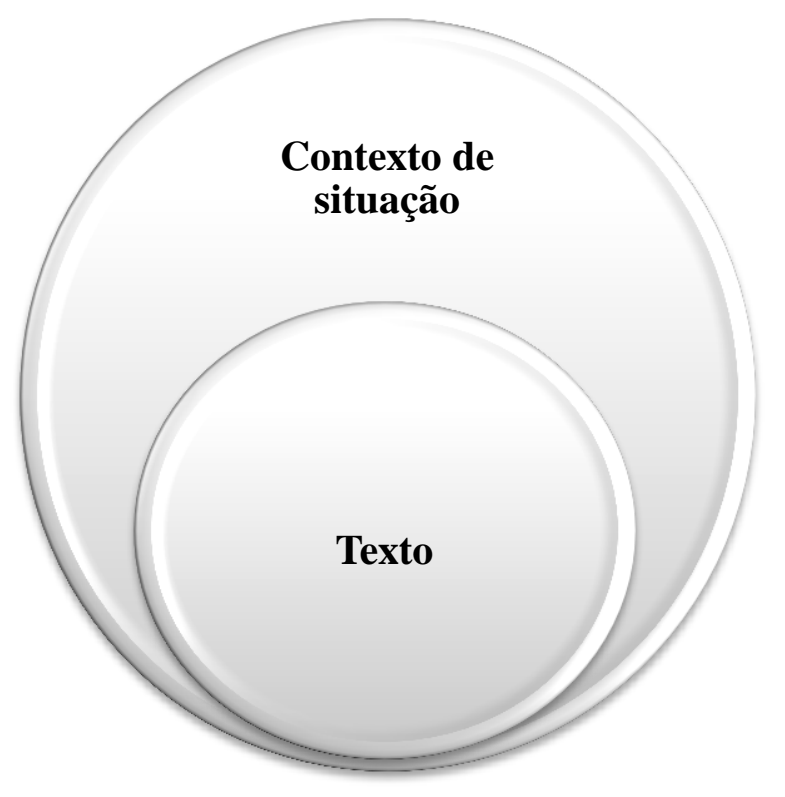

Figura 2: O texto e o contexto de situação.

Fonte: elaborada pela autora com base em Halliday e Matthiessen (2014)

\subsubsection{Contexto de Cultura}

O contexto de cultura está relacionado às características culturais que são refletidas nos textos produzidos pelos falantes/escritores/ilustradores pertencentes a uma cultura. Um exemplo são os filmes ou animações produzidos em um determinado país, cujos personagens revelam hábitos, costumes, modo de falar, expressões idiomáticas das pessoas pertencentes àquele lugar; e, quando os filmes são distribuídos para outros países e passam pelo processo de dublagem, têm a linguagem verbal parcialmente modificada, com adaptações de expressões idiomáticas, elogios, ofensas, palavrões, piadas, apelidos que produzem sentidos para aquela comunidade receptora do texto.

O contexto de cultura também delimita o texto que será utilizado em determinada situação ou não, pois dependendo da cultura, há maior ou menor probabilidade de que um texto seja produzido e não outro. Por exemplo, se um profissional se esqueceu de realizar uma tarefa demandada por seu chefe, o esperado é que o lapso seja corrigido e venha antecedido ou seguido por um pedido de desculpas e, talvez, do comprometimento de não mais 
negligenciar. Independente, de ser oral ou escrito, a probabilidade é de que esse texto seja mais formal, devido ao ambiente profissional e à relação de poder existente na situação. Se a falha fosse cometida entre amigos, a probabilidade maior é de que o texto seja oral e sem formalidade.

Desse modo, texto, na perspectiva da Gramática Sistêmico Funcional, é uma unidade semiótica que, independente da quantidade de orações que o constitua, produz significado dentro da situação em que foi criado e atinge o propósito social "exigido" pela cultura. E a organização desse texto demanda o empreendimento de escolhas léxico-gramaticais, ou seja, uma seleção das palavras disponíveis no léxico da língua, bem como uma seleção de estruturas possíveis disponíveis na língua. Além disso, são necessárias estruturas harmônicas e fluidas, características dadas pela coesão. E, também precisam apresentar coerência entre as ideias. Esses são os fatores linguísticos.

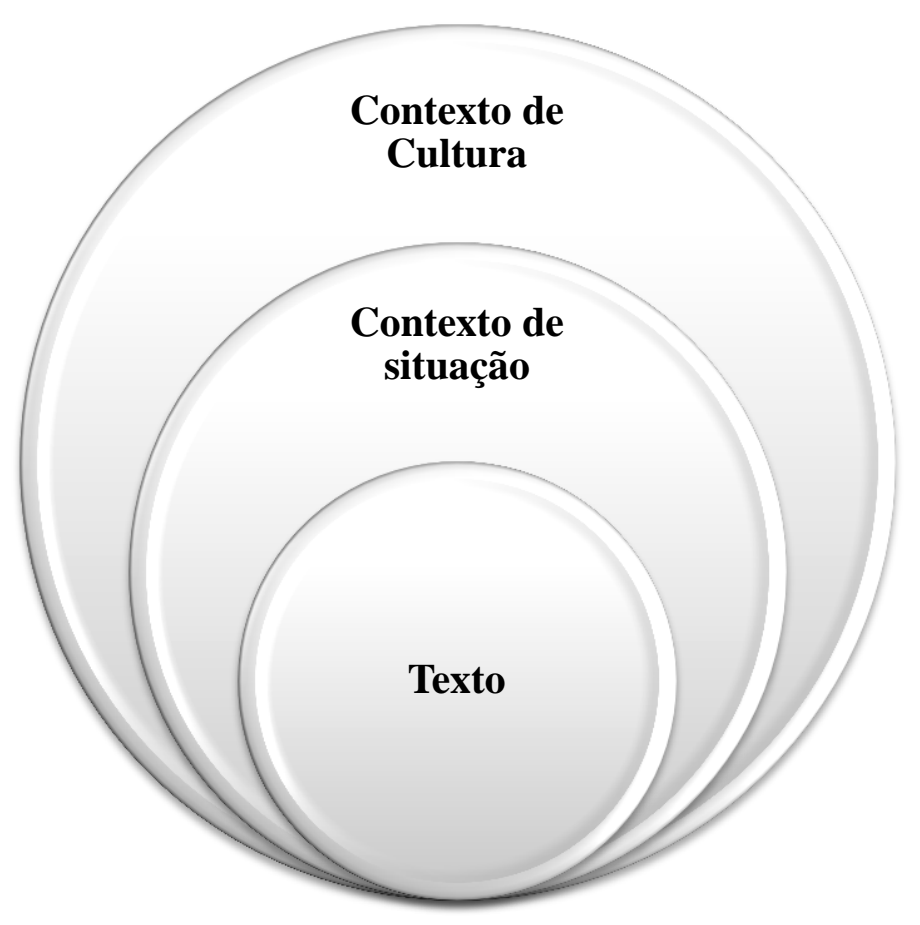

Figura 3: Texto, contexto de situação e contexto de cultura.

Fonte: elaborado pela autora com base em Halliday e Matthiessen (2014)

Logo, um texto não é apenas uma coleção de palavras ou orações justapostas, porque fatores extralinguísticos, como o ambiente, o nível de conhecimento que o produtor tem sobre o assunto, o tipo de relação existente entre os interlocutores e o modo como o texto é organizado, determinam as diferenças no registro. 


\subsection{GRAMÁTICA SISTÊMICO FUNCIONAL}

Halliday, em suas investigações acerca das relações entre língua e contexto, percebeu que as variações linguísticas encontradas nos textos eram determinadas pelas variáveis de contexto de situação - campo, relações e modo. Assim, o conhecimento que o produtor de um texto tem acerca dos acontecimentos (campo) vai determinar escolhas linguísticas. Também, as relações entre os participantes presentes nesse texto e o tipo de relação entre o produtor e o possível leitor ou ouvinte são evidenciadas no texto. E, o modo como as informações sobre acontecimentos e sobre as relações é organizado também é determinado pela situação. Então, considerando esses vínculos, Halliday criou a Gramática Sistêmico Funcional.

Nessa perspectiva, a língua é dividida em três sistemas - Transitividade, MODO e Modalidade e Estrutura Temática - os quais constituem as opções de uso para a construção dos significados. Segundo Fuzer e Cabral (2014, p. 19), “[...] é sistêmica, porque vê a língua como redes de sistemas linguísticos interligados, das quais nos servimos para construir significados, fazer coisas no mundo.” Também é funcional, porque textos criados em diversos contextos e com diferentes propósitos são estudados, descritos e comparados com o objetivo de que padrões de uso sejam identificados e compreendidos.

\subsubsection{Níveis de Análise}

O processo de descrição e análise de textos, com base no arcabouço teórico da Gramática Sistêmico Funcional, pode ter como objeto de estudo a oração - unidade linguística constituída de verbo -, pois é multifuncional, isto é, os significados construídos por ela, podem ser analisados, separados ou conjuntamente. E esses significados são experienciais, relacionais e textuais.

Contudo, a investigação objetivando a descrição de padrões pode ser realizada na unidade linguística acima do nível da oração e na unidade linguística abaixo do nível da oração. A primeira se trata do complexo oracional - enunciado composto por uma ou mais orações que podem apresentar uma relação de dependência uma com a outra, ou não. A segunda se refere aos sintagmas, que são agrupamentos de palavras conforme a função que desempenham na oração, e são classificados em sintagma nominal, sintagma verbal, sintagma adverbial ou frase proposicional.

Visto que, nesta pesquisa, a unidade linguística estudada é a oração, a teoria relacionada a ela será descrita com mais detalhes. 


\subsubsection{Metafunções}

Halliday, ao relacionar as variáveis de contexto de situação - campo, relações e modo - com a linguagem, identificou que esta possui outras funções que vão além da utilização para a comunicação. Essas funções são de representação dos acontecimentos, de representação das relações e de organização das informações no texto, que foram nomeadas, por Halliday, respectivamente, de metafunção ideacional ou experiencial, metafunção interpessoal e metafunção textual. E essa relação entre as variáveis de campo e as metafunções é representada no quadro 1 .

\section{Quadro 1: Relações entre Variáveis de contexto de Situação, metafunções e sistemas.}

\begin{tabular}{|lll|}
\hline Variáveis de Contexto de Situação & Metafunções & Sistemas \\
\hline Campo & Ideacional & transitividade \\
\hline Relações & Interpessoal & Modo e modalidade \\
\hline Modo & Textual & Estrutura Temática \\
\hline
\end{tabular}

Fonte: elaborado pela autora com base em Halliday e Matthiessen (2014)

\subsubsection{Metafunção Ideacional}

A metafunção ideacional ou experiencial é aquela função cujo propósito, segundo Halliday, é representar os eventos do mundo físico e os participantes envolvidos no desenrolar desses acontecimentos; ou ainda, representar o mundo da consciência, já que em diversos textos, os eventos que se passam na mente dos participantes são externados por meio da utilização de processos mentais. Assim, essa metafunção é a realização linguística do sistema da transitividade.

\subsection{Os processos e os participantes}

Os eventos são representados por processos e é com base na identificação do tipo de processo que os participantes são definidos. Dessa forma, os elementos constituintes do sistema da transitividade são os processos, os participantes e as circunstâncias.

\section{a Processos Materiais}

Os processos são classificados em material, relacional, mental, existencial, comportamental e verbal. Os significados construídos pelos processos materiais são de que algo está sendo realizado e transformado, e os participantes que podem compor as orações com esses processos são ator, meta, escopo e beneficiário; 
Ex.

\begin{tabular}{|l|l|l|l|}
\hline Logicamente, & os primeiros & compram (importam) & as matérias - primas dos segundos \\
\hline elemento interpessoal & ator & material & meta \\
\hline
\end{tabular}

\section{b Processos Relacionais}

A função dos processos relacionais é conectar um participante a outro, ou seja, um participante a sua identidade ou a sua característica. Por isso, os processos relacionais podem ser identificativos e, nesse caso, os participantes são identificador e identificado, como se observa no exemplo abaixo.

Ex.

\begin{tabular}{|l|l|l|}
\hline $\begin{array}{l}\text { Dois importantes símbolos } \\
\text { da globalização }\end{array}$ & são & $\begin{array}{l}\text { a internet (rede mundial de computadores) e o } \\
\text { sistema financeiro [...] }\end{array}$ \\
\hline identificado & relacional identificativo & identificador \\
\hline
\end{tabular}

ou pode ser atributivos, e os participantes, portador e atributo.

\begin{tabular}{|l|l|l|l|}
\hline porque & todas as economias & estão & integradas, \\
\hline el. textual & portador & relacional atributivo & atributo \\
\hline
\end{tabular}

\section{c Processos Mentais}

Aos processos mentais cabe a função de expressar os significados da consciência, logo, o experienciador - um dos participantes do processo mental - é humano, ou algum ser personificado, isto é, com capacidades cognitivas humanas. O outro participante do significado mental é o fenômeno, e esses processos podem ser perceptivos, que estão relacionados à percepção do mundo por meio dos órgãos do sentido; cognitivos, que evidenciam o que ocorre no mundo interno da consciência; desiderativos, que revelam aquilo que é desejado; e emotivos, que exprimem sentimentos e emoções em relação a algo ou alguém.

Ex.

\begin{tabular}{|l|ll|l|l|ll|lll|}
\hline Mas & a & partir dos & essa integração & conheceu & um & novo & com & a & Terceira \\
\hline
\end{tabular}




\begin{tabular}{|l|l|l|l|l|l|}
\hline & anos 1980 & $\begin{array}{l}\text { mundial, agora } \\
\text { chamada } \\
\text { globalização, }\end{array}$ & & impulso & $\begin{array}{l}\text { Revolução Industrial e a } \\
\text { ligação [...] }\end{array}$ \\
\hline el. textual & circ. - tempo & experienciador & $\begin{array}{l}\text { mental } \\
\text { cognitivo }\end{array}$ & fenômeno & circ. - causa \\
\hline
\end{tabular}

\section{d Processos Existenciais}

Os significados expressos pelos processos existenciais são da existência de algo, portanto, nas orações cujos processos signifiquem a existência de algo, os verbos mais comuns são os conhecidos na gramática convencional como impessoais - haver, existir, acontecer e ocorrer - e o único participante desse tipo de processo é o existente.

Ex.

\begin{tabular}{|l|l|l|l|}
\hline $\begin{array}{l}\text { Nas décadas de } \\
1950 \text { e } 1960\end{array}$ & havia & apenas & $\begin{array}{l}\text { empresas } \\
\text { multinacionais, principalmente norte- } \\
\text { americanas GM, Ford, ITT, Exxon, etc.). }\end{array}$ \\
\hline circ. - tempo & processo existencial & el. interpessoal & existente \\
\hline
\end{tabular}

\section{e Processos Comportamentais}

Os processos comportamentais expressam significados do comportamento tipicamente humano como cantar, escrever e falar, e os participantes típicos desses processos são o comportante e o comportamento.

Ex.

\begin{tabular}{|l|l|l|l|}
\hline$e$ & [as pessoas] $^{2}$ & assistem & aos mesmos filmes. \\
\hline elemento textual & comportante & comportamental & comportamento \\
\hline
\end{tabular}

\section{fProcessos Verbais}

Os processos verbais carregam significados relativos a eventos em que se utiliza a propriedade da fala. Então, processos como dizer, perguntar, afirmar constroem esses significados juntamente com os participantes dizente, verbiagem, receptor e alvo. E, como é

\footnotetext{
${ }^{2}$ A expressão encontra-se entre colchetes por evidenciar um termo elíptico no texto.
} 
bastante comum que a oração verbal projete - um dos participantes seja uma outra oração -, a oração projetada costuma ser a verbiagem, que pode ser um relato - discurso indireto -, ou uma citação - discurso direto.

Ex.

\begin{tabular}{|l|l|l|}
\hline Por isso & se diz & que houve uma aceleração no ritmo do tempo \\
\hline circ. - causa & processo verbal & verbiagem \\
\hline
\end{tabular}

\subsection{Circunstâncias}

As circunstâncias, realizadas linguisticamente por grupos adverbiais ou grupos preposicionais, podem estar presentes em quaisquer orações, acrescentando ideias de como ocorreu algum evento - modo -, onde ocorreu o evento - lugar -, quando ocorreu - tempo -, o porquê de determinado evento ter acontecido - causa - entre outras.

Ex.

\begin{tabular}{|l|l|l|}
\hline Atualmente, & calcula-se & que mais de 55 mil empresas podem ser consideradas multinacionais, \\
\hline circ. - tempo & mental & fenômeno \\
\hline
\end{tabular}

\begin{tabular}{|l|l|l|l|}
\hline em qualquer região do planeta, & atualmente, & há & $\begin{array}{l}\text { uma expansão dos shopping centers, que } \\
\text { são praticamente iguais em todas as } \\
\text { partes, }\end{array}$ \\
\hline circunstância - lugar & circ. - tempo & existencial & existente \\
\hline
\end{tabular}

Segundo Martin e Rose (2007, p. 74), na perspectiva da semântica discursiva, a oração constrói atividade, cujos elementos centrais são o processo, as pessoas e as coisas que estão relacionadas a ela. E elementos como qualidades e circunstâncias são mais periféricos. Porém, além desses recursos gramaticais que constroem a experiência, ainda acrescentam dois conjuntos complementares de padrões que auxiliam na representação do campo: as relações conjuntivas, que unem as orações, organizando os eventos como uma sequência de atividades; e as relações lexicais, que são responsáveis por construir o campo do texto por meio de processos, pessoas, coisas, qualidades, ou seja, por meio de significados. 
Ainda, de acordo com Martin e Rose (2007, p.75-76), as relações lexicais podem ser taxonômicas, nucleares e de sequências de atividades - constituem o sistema de ideação. ${ }^{3} \mathrm{~A}$ primeira se trata da relação entre os elementos de oração para oração, que envolve recursos como o uso de repetição, sinonímia, contraste, classe ou parte. A segunda se trata da relação entre os elementos integrantes da oração, onde alguns serão mais centrais e outros mais periféricos. E, com base na observação dos processos e das nominalizações de um texto, identifica-se a sequência de atividades, que é o terceiro tipo de relação lexical.

\section{Quadro 2: Relações do Sistema de Ideação}

\begin{tabular}{|l|l|l|}
\hline & Relações taxonômicas & $\begin{array}{l}\text { Entre os elementos de oração a oração } \\
\text { Reino Unido - Inglaterra - Grã-Bretanha }\end{array}$ \\
\hline Ideação & Relações nucleares & $\begin{array}{l}\text { Configurações de elementos dentro de cada oração chineses - } \\
\text { compram - ações }\end{array}$ \\
\hline & $\begin{array}{l}\text { Sequências de atividades } \\
\text { De processo para processo em série de orações } \\
\text { produzir - se especializou - começou a impor - conquistou }\end{array}$ \\
\hline
\end{tabular}

Fonte: Adaptado de tabela de Martin e Rose (2007, p. 76)

\subsubsection{Metafunção interpessoal}

De acordo com Halliday e Matthiessen (2014),

Os tipos mais fundamentais de discurso, que estão por trás de todos os tipos mais específicos que possamos eventualmente ser capazes de reconhecer, são apenas dois: (i) dar e (ii) exigir (ver Halliday, 1984a). Ou o falante está dando algo ao ouvinte ou ele está exigindo algo dele [...] Mesmo essas categorias elementares já envolvem noções complexas: dar meios "convidar a receber" e exigir meios "convidar a dar". O orador não está apenas fazendo algo por si mesmo; Ele também está exigindo algo do ouvinte. Normalmente, portanto, um "ato" de falar é algo que poderia ser mais apropriadamente chamado de interagir: é uma troca, em que dar implica receber e exigir implica dar em resposta. (HALLIDAY e MATTHIESSEN, 2014, p.135).

As relações são codificadas nos textos pela metafunção interpessoal, que pode expressar propostas, quando há troca de bens e serviços; ou pode expressar proposições, quando há troca de informações. É por meio da análise dessa metafunção que se pode identificar a modalização ou não nos discursos, as relações de poder, as atitudes e avaliações que são

\footnotetext{
${ }^{3}$ Segundo Martin e Rose, o sistema de ideação está relacionado com a forma como a experiência é construída no discurso, ele se concentra em sequências de atividades, as pessoas e coisas envolvidas nelas, suas qualidades e os lugares associados a elas.
} 
construídas. E, quando o texto é investigado sob a perspectiva das interações com os propósitos de convidar alguém para fazer algo, ou responder alguma pergunta, ou ordenar alguma tarefa, entre outras formas de relações, o sistema a ser considerado é o de MODO e Modalidade. E as orações que expressam esses significados podem ser declarativas, interrogativas ou imperativas.

\subsection{Constituição da Metafunção Interpessoal}

No sistema de MODO e Modalidade, a oração é dividida em dois componentes: modo e resíduo, que se subdividem em outros componentes, com maior ou menor relevância, a depender do que o pesquisador está investigando.

\section{a Modo}

$\mathrm{Na}$ análise do sistema de MODO e Modalidade, os significados mais importantes estão no componente Modo, que pode ser constituído pelo sujeito da oração, ou seja, quem ou o que é o assunto; pelo finito, que é o elemento do grupo verbal que carrega os significados de a) polaridade - se há a presença do não, a polaridade é negativa,

Ex.

\begin{tabular}{|l|l|l|l|l|}
\hline$e$ & entre 20 e 40 milhões de famílias & não & têm & moradia. \\
\hline el. textual & sujeito & polaridade negativa & finito - presente & resíduo \\
\hline
\end{tabular}

e, se não há a presença do não, trata-se de polaridade positiva -;

Ex.

\begin{tabular}{|l|l|l|}
\hline As regiões do globo cujos[...] & são & as principais receptoras e emissoras de turistas. \\
\hline sujeito & finito - presente & resíduo \\
\hline
\end{tabular}

b) de tempo - presente, pretérito ou futuro -;

Ex.

\begin{tabular}{|l|l|l|l|}
\hline $\begin{array}{l}\text { Nas próximas } \\
\text { décadas, }\end{array}$ & $\begin{array}{l}\text { os países } \\
\text { emergentes }\end{array}$ & serão & $\begin{array}{l}\text { os maiores geradores de megacidades, enquanto } \\
\text { o crescimento desse tipo de aglomeração urbana } \\
\text { nos países desenvolvidos tenderá à estabilização. }\end{array}$ \\
\hline el. ideacional & sujeito & finito -futuro & resíduo \\
\hline
\end{tabular}


c) assim como a modalidade, representada por meio de verbos como poder, dever e precisar.

Ex.

\begin{tabular}{|l|l|l|l|l|l|l|}
\hline Além disso, & $\begin{array}{l}\text { caso seja confirmada } \\
\text { a previsão[...] }\end{array}$ & $\begin{array}{l}\text { a produção } \\
\text { agrícola }\end{array}$ & também & poderá & sofrer & grande impacto \\
\hline el. textual & oração condicional & sujeito & el. textual & $\begin{array}{l}\text { finito - futuro } \\
\text { modalidade }\end{array}$ & resíduo \\
\hline
\end{tabular}

A modalidade também pode ser expressa por meio de adjuntos de comentário, que normalmente estão posicionados no início da oração;

Ex.

\begin{tabular}{|c|c|c|c|}
\hline Na verdade, & $\begin{array}{l}\text { a globalização, junto com a } \\
\text { Terceira Revolução Industrial, }\end{array}$ & permitiu & $\begin{array}{l}\text { que alguns países subdesenvolvidos } \\
\text { se modernizassem [...] }\end{array}$ \\
\hline $\begin{array}{ll}\text { adjunto } & d e \\
\text { comentário } & \end{array}$ & sujeito & finito - pretérito & resíduo \\
\hline
\end{tabular}

e também, pode ser manifestada por meio de adjuntos modais, relacionados ao finito.

Ex.

\begin{tabular}{|l|l|l|l|l|}
\hline em 1950 & elas & eram & apenas & 86 \\
\hline el. ideacional & sujeito & $\begin{array}{l}\text { finito } \\
\text { pretérito }\end{array}$ & adjunto modal & resíduo \\
\hline
\end{tabular}

\section{b Resíduo}

O resíduo pode ser constituído pelo predicador - caso haja perífrase verbal, retira-se o finito e o que sobra do grupo verbal é o predicador -; o complemento, que completa o sentido da oração; e o adjunto circunstancial que, conforme a subseção 1.2.2.2.2, é um constituinte do Sistema da Transitividade, logo não é analisado no Sistema de MODO e Modalidade.

\subsubsection{Metafunção Textual}

Na perspectiva da Gramática Sistêmico Funcional, a linguagem também é utilizada para garantir a organização e a coerência dos significados experienciais e interpessoais. E, assim como a metafunção ideacional representa os eventos do mundo físico e do mundo da 
consciência, e a metafunção interpessoal representa as relações, a metafunção textual representa a mensagem e faz parte de dois sistemas: Estrutura da Informação e Estrutura Temática. Assim, se o objetivo de um pesquisador for a investigação do modo como a linguagem foi organizada, os significado a serem descritos e analisados são os textuais.

\subsection{Estrutura da Informação}

Quando a análise da oração como mensagem concentra-se na estrutura da informação, a unidade linguística é dividida em informação dada e informação nova. A primeira representa aquilo que já é conhecido, familiar, ou alguma informação que está sendo retomada. A segunda traz as informações novas, que não podem ser resgatadas nas informações escritas ou ditas anteriormente.

Ex.

\begin{tabular}{|l|l|}
\hline $\begin{array}{l}\text { O número de países exportadores } \\
\text { de bens industrializados }\end{array}$ & cresceu muito com a expansão da atividade industrial pelo mundo, [...] \\
\hline Dado & Novo \\
\hline
\end{tabular}

\section{a Estrutura Temática}

Ao lado da Estrutura da Informação - informação dada e informação nova - pode-se analisar a Estrutura Temática da oração, e nesse caso, a mensagem também é dividida em duas partes: o Tema e o Rema.

Ex.

\begin{tabular}{|l|l|}
\hline $\begin{array}{l}\text { O número de países exportadores } \\
\text { de bens industrializados }\end{array}$ & cresceu muito com a expansão da atividade industrial pelo mundo, [...] \\
\hline Tema & Rema \\
\hline
\end{tabular}

\section{Tema Ideacional}

Tema é o componente presente na parte inicial da oração e ele pode acrescentar significados experienciais com um participante,

Ex. 


\begin{tabular}{|l|l|l|}
\hline & & além de dois não euporeus: os Estados Unidos e o Japão. \\
\hline tema ideacional - identificado & rema & \\
\hline
\end{tabular}

com um adjunto circunstancial,

Ex.

\begin{tabular}{|c|c|c|c|c|c|}
\hline $\begin{array}{ll}\text { Logo } & \text { em } \\
\text { seguida } & \end{array}$ & principalmente & no século XIX & $\begin{array}{ll}\text { vários } & \text { outros } \\
\text { países } & \end{array}$ & seguiram & $\begin{array}{l}\text { o exemplo do } \\
\text { Reino Unido. }\end{array}$ \\
\hline $\begin{array}{l}\text { tema ideacional } \\
\text { - circunstância }\end{array}$ & rema & & & & \\
\hline
\end{tabular}

ou com um processo

Ex.

\begin{tabular}{|l|l|l|l|}
\hline Basta & [você] & lembrar & $\begin{array}{l}\text { que em 1865, quando o presidente dos Estados } \\
\text { Unidos, Abraham Lincoln, foi assassinado, a } \\
\text { notícia levou treze dias para chegar à Europa. }\end{array}$ \\
\hline tema ideacional - processo & rema \\
\hline
\end{tabular}

Tema Interpessoal

O primeiro elemento posto em posição temática pode ser um constituinte da metafunção interpessoal, representado por um pronome interrogativo ou por um adjunto de comentário.

Ex.

\begin{tabular}{|l|l|l|l|}
\hline Logicamente, & os primeiros & compram (importam) & as matérias - primas dos segundos \\
\hline tema interpessoal & tema ideacional & rema \\
\hline
\end{tabular}

\section{Tema Textual}

Conjunções ou marcadores discursivos, responsáveis pela articulação das informações presentes nos textos, também podem aparecer em posição temática, e, neste caso, ocorre um tema textual. 


\begin{tabular}{|l|l|l|l|l|}
\hline $\boldsymbol{e}$ & [vários outros países] & se & industrializaram, & $\begin{array}{l}\text { passando a vender também produtos } \\
\text { industrializados no mercado mundial. }\end{array}$ \\
\hline tema textual & tema ideacional & rema & \\
\hline
\end{tabular}

Contudo, como se observa, nos dois últimos exemplos, há dois temas em cada oração. Isso ocorre, porque constituintes da metafunção interpessoal e da metafunção textual podem ser colocados em posição temática, porém precisam ser seguidos por um tema ideacional, que será o assunto. Assim, quando há mais de um tema na oração, é classificado como tema múltiplo.

Ex.

\begin{tabular}{|l|l|l|l|l|l|}
\hline Mas & não & foi & somente & a China & $\begin{array}{l}\text { que mudou radicalmente sua } \\
\text { posição na Divisão } \\
\text { Internacional do Trabalho. }\end{array}$ \\
\hline $\begin{array}{l}\text { tema } \\
\text { textual }\end{array}$ & $\begin{array}{l}\text { tema } \\
\text { interpessoal }\end{array}$ & tema ideacional & rema & \\
\hline \multicolumn{2}{|l}{ tema múltiplo } & & & \\
\hline
\end{tabular}

Rema

De acordo com Halliday, para a identificação do tema, deve-se observar a oração, e tudo aquilo que estiver na posição inicial até o primeiro elemento constituinte da metafunção experiencial - processo, participante ou circunstância - trata-se do tema, o que estiver representado depois é o rema, que é a informação desenvolvida sobre o rema.

A importância do estudo da Estrutura Temática está no fato de que o falante/ escritor, ao organizar o seu discurso, evidencia algumas estruturas, colocando-as em posição temática, mas pode resguardar as informações novas para serem apresentadas na segunda parte da oração, fato que torna necessário o olhar atento do pesquisador para as diversas possibilidades de estruturas, que podem ser constituídas de

a) um tema + um rema:

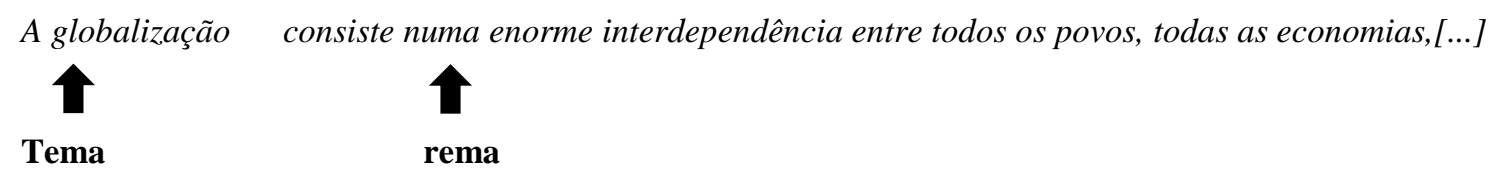


b) ou um tema + diversos remas:

as pessoas cada vez mais comem nas mesmas cadeias de fast-food,

bebem os mesmos refrigerantes,

vestem jeans ou tênis de marcas globais,

ouvem músicas semelhantes

e assistem aos mesmos filmes.

Tema

remas

c) ou um tema + um rema subdivido.

A Divisão Internacional do Trabalho

e [A Divisão Internacional do Trabalho]

Tema manteve [as desigualdades internacionais]

até mesmo agravou as desigualdades internacionais.

remas

Com a compreensão das possibilidades de estruturas - Estrutura Temática -, diversos estudos estão sendo desenvolvidos e contribuem para a geração de conhecimento e informações levados a vários contextos, principalmente o escolar, com ensino de produção textual intervencionista.

\section{Quadro 3: Resumo para análises das metalinguagens}

\begin{tabular}{|l|l|l|}
\hline Tipo de análise & Metalinguagem \\
\hline Constituição & Grupo nominal, Grupo verbal, Grupo adverbial, Grupo Conjuntivo, Grupo Preposicional. \\
\hline Experiencial & Processos e Participantes & \multicolumn{2}{|l|}{ Circunstâncias } \\
\hline transitividade & $\begin{array}{l}\text { Material - ator, meta, escopo e beneficiário } \\
\text { Comportamental - comportante e comportamento } \\
\text { Mental - experienciador e fenômeno } \\
\text { Verbal - dizente, verbiagem, receptor e alvo } \\
\text { Existencial - existente }\end{array}$ & $\begin{array}{l}\text { Extensão: tempo, lugar } \\
\text { Localização: tempo, lugar } \\
\text { Maneira: meios, qualidade, } \\
\text { complemento } \\
\text { ponto de vista }\end{array}$ \\
\hline
\end{tabular}




\begin{tabular}{|c|c|c|c|c|c|c|c|c|}
\hline & \multicolumn{5}{|c|}{$\begin{array}{l}\text { Relacional atributivo - portador e atributo } \\
\text { Relacional identificativo - identificador e identificado }\end{array}$} & \multicolumn{3}{|c|}{$\begin{array}{l}\text { Função: } \\
\text { Acompanhamento: } \\
\text { Causa: } \\
\text { Contingência: } \\
\text { assunto: }\end{array}$} \\
\hline \multirow{2}{*}{$\begin{array}{l}\text { Interpessoal } \\
\text { Incluem: modo e } \\
\text { função de fala }\end{array}$} & \multicolumn{5}{|l|}{ Modo } & \multicolumn{3}{|l|}{ Resíduo } \\
\hline & Sujeito & $\begin{array}{l}\text { Adjunt } \\
\text { o } \\
\text { modal }\end{array}$ & $\begin{array}{l}\text { Adjunto de } \\
\text { comentário }\end{array}$ & $\begin{array}{l}\text { Finito: } \\
\text { tempo } \\
\text { Ou } \\
\text { modali } \\
\text { dade }\end{array}$ & polaridade & $\begin{array}{l}\text { Predica } \\
\text { dor }\end{array}$ & Complemento & Adjunto \\
\hline \multirow[t]{2}{*}{ Textual } & \multicolumn{5}{|l|}{ Tema } & \multirow{2}{*}{\multicolumn{3}{|c|}{ Rema }} \\
\hline & Textual & & Interpesso & Tóp & & & & \\
\hline
\end{tabular}

Fonte: adaptado de Butt et al (1994)

\subsubsection{Metáfora Gramatical}

Para Halliday, a gramática de cada língua possibilita a transformação da experiência em significados e a configuração semântica realiza-se léxico-gramaticalmente por expressão congruente, ao passo que há outros sentidos que são transferidos, chamados de incongruentes ou metafóricos. A congruência traduz-se na tipicidade linguística, na qual, por exemplo, pessoas, objetos e lugares são representados gramaticalmente por nomes, e ações são representadas gramaticalmente por verbos. Essa tipicidade surge com o desenvolvimento da linguagem, nos primeiros anos da infância. Já a incongruência é a maneira metafórica de gramaticalizar os significados . Essa incongruência é chamada de metáfora gramatical, que segundo Halliday (1993a) é

[...] uma substituição de uma classe gramatical, ou uma estrutura gramatical por outra; por exemplo, sua partida ao invés de ele partiu. Aqui as palavras (itens lexicais) são os mesmos; o que mudou é o seu lugar na gramática. Em vez do pronome ele + verbo partiu, funcionando como Ator + Processo em uma oração, temos o grupo nominal sua partida, determinado por dêitico + Coisa, funcionando como substantivo.(HALLIDAY, 1993a, p.79).

Considerada como uma realização marcada, a metáfora gramatical tem sentido menos típico. E não se trata de simples refraseamento, pois ao construir um enunciado de outra forma, cria-se novo significado, novo construto da experiência. Ainda de acordo com Halliday e Matthiessen (2004), a capacidade de compreender o movimento entre congruência e incongruência ocorre mais tarde, próximo à puberdade, indicando um amadurecimento 
cognitivo para utilizar esse recurso linguístico tão comum nos discursos científicos, nos discursos acadêmicos e também nos discursos normativos.

Ao contrário da metáfora interpessoal, o outro tipo de metáfora gramatical, metáfora ideacional, é aprendido mais tarde pelas crianças e não faz parte da gramática da conversa espontânea ordinária que as crianças encontram na casa e no bairro; em vez disso, está associada aos discursos da educação e da ciência, da burocracia e da lei. É provável que as crianças encontrem o tipo ideacional de metáfora quando atingem os níveis superiores da escola primária (ver por exemplo Christie \& Derewianka, 2008; Derewianka, 1995); mas sua força plena só aparecerá quando começarem a lidar com os discursos especializados do ensino secundário baseado em disciplinas. (HALLIDAY E MATTHIESSEN, 2004, p. 709)

Wignell, Martin e Eggins (1993), ao fazerem descrição e análise do livro didático de Geografia, a fim de identificarem como é construído o discurso nessa ciência, concluíram que a linguagem é usada para representar o mundo experiencial, para ordenar o mundo experiencial com taxonomias de campos específicos e para explicar o mundo experiencial. E, para que esses objetivos sejam atingidos, termos técnicos são usados para referir-se às entidades e às atividades e, a maioria desses termos técnicos são substantivos. Existem alguns verbos técnicos, mas, de um modo geral, os termos técnicos são substantivos emprestados das línguas vernáculas, ou são termos técnicos utilizados em outras áreas.

Uma forma comum de metáfora gramatical é a nominalização, que é a reconstrução de um processo como uma coisa, como se observa nos exemplos.

Ex.:

Modo incongruente

Segundo previsões da ONU,

Substantivo

para adequação à produção

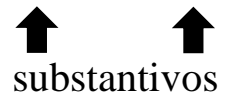

Modo congruente

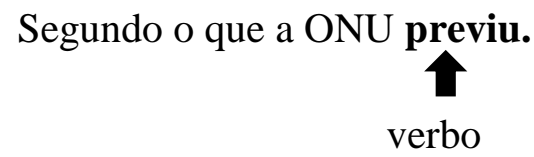

para adequar o que se produz

verbos

Para Wignell, Martin e Eggins (1993, p. 160), a razão para tantas nominalizações no discurso científico pode estar relacionada a dois motivos: a primeira diz respeito à estrutura do argumento científico que é desenvolvido em cadeias, ou seja, as construções gramaticais são criadas para representar o passo, a etapa; contudo, antes de relatar o próximo passo, o 
último é retomado em forma de nominalização, que pode funcionar bem como tema da próxima oração. A outra explicação residiria no fato de que, apesar da necessidade da ciência retratar a dinâmica dos fenômenos, os cientistas tiveram que criar um universo feito de coisas, desenvolver taxonomias de objetos; e os fenômenos representados por verbos foram nominalizados, atribuindo ao substantivo uma densidade lexical alta.

Quando se escreve de modo mais congruente, há uma complexidade gramatical maior, devido a maior quantidade de orações; contudo, há menos densidade lexical, visto que a carga semântica não sobrecarrega uma ou mais palavras. Por outro lado, quando há um condensamento das ideias, temos menos complexidade gramatical, porém, mais densidade lexical. (HALLIDAY E MATTHIESSEN, 2004, p. 710)

Butt et al (1994, p.75) apontam três explicações para o uso das nominalizações. A primeira está relacionada à necessidade de congelar um evento no tempo e torná-lo um objeto que participa de um tipo diferente de processo. A segunda, ao fato da transformação de um evento em um substantivo oferecer oportunidades de contar, descrever, classificar e especificar essa entidade. E a terceira razão diz respeito ao registro, pois as nominalizações são menos utilizadas em situações familiares, do cotidiano, e se manifestam com mais frequência em contextos mais formais, como o contexto científico.

Martin e Rose (2007, p. 107) afirmam que, por um lado, a versão nominalizada permite conotações que não seriam possíveis utilizando os processos.

Ex.:

[...] um enorme crescimento do comércio e do turismo entre as nações.

E, por outro lado, o desempacotamento das nominalizações revela as pessoas e coisas que foram elididas.

\subsection{GÊNEROS TEXTUAIS}

Estudos sobre gêneros textuais, com base em diferentes perspectivas teóricas, têm sido desenvolvidos por pesquisadores em diversos países, e metodologias de ensino explícito de gêneros têm sido pesquisadas e aplicadas em inúmeras universidades e escolas de ensino fundamental e médio, dada a significativa relação entre gêneros textuais e as práticas sociais. Os estudos sobre gêneros textuais desenvolvidos no Brasil e em outros países (África do Sul, Quênia, Uganda, Tanzânia, Suécia, Finlândia, Reino Unido, Espanha, Portugal, EUA, Chile, Hong Kong e na Austrália), sob a perspectiva da GSF, buscam investigar de que forma essa abordagem pode contribuir para que a aprendizagem de leitura e de escrita seja mais eficaz 
para os alunos, pois, segundo Halliday e Hasan (1989), pode-se trabalhar com gêneros diversos, na sala de aula, por três objetivos: aprendizagem e/ou ampliação do repertório dos gêneros dos estudantes; ensino e conscientização dos gêneros e ensino por meio dos gêneros.

Para pesquisadores da escola de Sydney, que, desde a década de 80 desenvolvem pesquisas com textos, especialmente os pertencentes ao contexto escolar, a fim de criarem uma política de educação intervencionista na Austrália, a investigação de todos os elementos que envolvem a produção de texto, sendo eles explícitos ou implícitos, é fulcral, pois com o entendimento de todos esses detalhes é possível a sistematização das informações acerca dos contextos sociais, especialmente às relacionadas ao que é esperado que os alunos saibam ao final de cada etapa do ensino, para que as ações sejam implementadas.

Assim, para esses estudiosos, na tessitura de qualquer texto, para que tenha significado e atinja o propósito social para o qual foi tecido, as palavras (léxico) que o compõem são organizadas dentro de estruturas previstas (gramática); formando grupos de palavras, orações e/ ou complexos oracionais; que devem apresentar coesão, isto é, conexão e fluidez entre as ideias; bem como coerência.

\subsubsection{Bases Teóricas}

De acordo com Martin e Rose, os trabalhos de Mitchell (1957), de Labov e Waletzky (1967) e Hasan (1977 e 1984), sobre estrutura esquemática dos textos, foram a base para o início de suas pesquisas acerca de gêneros, sob a perspectiva da Gramática Sistêmico Funcional. Pois as pesquisas desses estudiosos comprovam que os textos são constituídos de partes estáveis, nomeadas de etapas; e essas etapas são estruturadas em fases, que são bastante variáveis, podendo estar presentes em um texto e em outro não. Logo, a definição de que um texto possui este ou aquele propósito, depende da identificação das etapas que o constituem.

As pesquisas de Halliday, que relacionam as três funções sociais da linguagem metafunção ideacional, metafunção interpessoal e metafunção textual -, descobertas por ele, e as variáveis de contexto de situação - campo, relações e modo -, descobertas por Malinowski, também foram determinantes para a construção da base teórica da Teoria de Gêneros e Registros, da Escola de Sydney, pois, segundo Martin e Rose (2008, p. 16), os textos podem variar de acordo com a situação. Porém, após análises, os pesquisadores constataram que os eventos e as relações podem ser representados de diversos modos em variados tipos de textos, então compreenderam que o que define os gêneros são os propósitos sociais de uma determinada cultura, isto é, o que se pretende alcançar com aquele texto. E, ainda afirmam 
que as culturas parecem envolver um amplo, mas potencialmente definível conjunto de gêneros, que são reconhecíveis aos membros de uma cultura, ao invés de uma selva imprevisível de situações sociais.

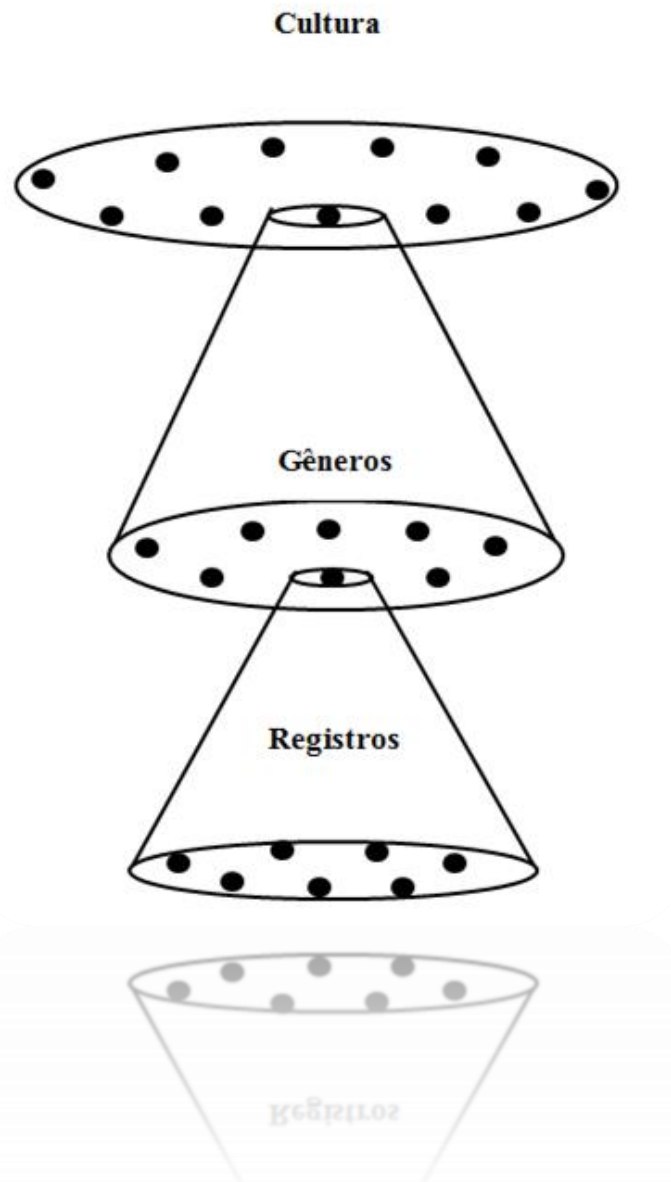

Figura 4: representação do universo de gêneros e registros em uma cultura

Fonte: elaborado pela autora com base em Martin e Rose (2008)

Eggins e Martin (1994) afirmam que

A abordagem sistêmica, não só fornece uma descrição detalhada das funções e estruturas da língua * (cfr.Halliday, 1985b), mas vai mais longe e relaciona as dimensões contextuais de registro junto à organização semântica e gramatical da própria língua. Isso resulta em uma explicação funcional e coerente sobre a razão pela qual algumas dimensões de contexto são importantes e outras não. Da mesma forma, a aproximação sistêmica desenvolveu especificações detalhadas das estruturas de etapas e das características de realização dos distintos gêneros, assim como concepções sobre a maneira como os gêneros podem se relacionar com outros gêneros e evoluir com eles. (EGGINS e MARTIN, 1994, p. 344) 


\subsubsection{Gêneros para Escola de Sydney}

Martin e Rose (2008, p.6) definem os gêneros textuais como "configurações recorrentes de significados que retratam os propósitos sociais de uma determinada cultura". De acordo com o que se pretende alcançar com os textos, gêneros são criados, e outros desaparecem, pois, conforme Fairclough (2003a), as práticas sociais ${ }^{4}$ moldam textos. Logo, se estruturas e práticas sociais mudam, as formas de agir, bem como os gêneros, também mudam.

Em outras palavras, Martin e Rose (2008, p.6) afirmam que gêneros são processos sociais encenados, com objetivos. São processos sociais, porque falantes, escritores, ilustradores produzem seus textos para alguém. São encenados, pois, são constituídos de etapas, que, se não forem contempladas, possivelmente o objetivo do texto não será alcançado. Assim, a investigação das semelhanças e diferenças entre textos, bem como de seus propósitos apontam padrões para a compreensão da composição dos gêneros pertencentes a uma cultura.

\subsubsection{Teoria de Gêneros e Registros}

A Teoria de Gêneros e Registros (doravante TGR) consiste em um alicerce teóricometodológico para análise de textos. Esse alicerce oferece ferramentas para uma investigação que objetiva descrever as características linguísticas de textos e explicar o que os tornam pertencentes a uma determinada categoria de gêneros textuais e não a outras. Pois, um tema pode ser abordado em uma variedade de gêneros, como por exemplo, o tema globalização pode ser relatado; ou pode ser explicado, tendo suas causas e consequências apontadas; ou pode ser exposto com base em uma perspectiva em que apenas os pontos positivos são apresentados; ou ainda pode ser discutido - situação em que argumentos favoráveis e desfavoráveis são considerados para a articulação das ideias. Assim, como identificar o(s) gênero(s) presente(s) em determinado texto? De acordo com Eggins e Martin (1994), com base na identificação do propósito social do texto e na descrição e identificação das características linguísticas pode-se responder a esse questionamento.

[...] a Teoria de Gênero e Registro deve prover uma metodologia para realizar análises textual, e também deve proporcionar uma concepção acerca da maneira como o contexto situacional e o contexto cultura se expressam sistematicamente nas eleições de linguagem. Desse modo,

\footnotetext{
${ }^{4}$ Articulações de diferentes tipos de elementos sociais associados a áreas particulares da vida social - moldam textos. Então, se estruturas e práticas sociais mudam, as formas de agir, bem como os gêneros também se modificam.
} 
uma teoria madura de gênero e registro envolve tanto um informe detalhado da linguagem como uma teoria de contexto e a relação entre contexto e linguagem. (MARTIN e EGGINS, 1994, p. 344)

\subsubsection{Gêneros do Contexto Escolar}

Conforme se observa de forma mais detalhada, no quadro 4, de acordo com Muniz da Silva (2015), os principais gêneros presentes no currículo escolar encontram-se divididos em famílias, classificadas como: das Estórias, das Histórias, das Explicações, dos Procedimentos, dos Relatos, dos Argumentos e Respostas.

\section{Quadro 4: Classificação dos gêneros escolares para a Escola de Sydney.}

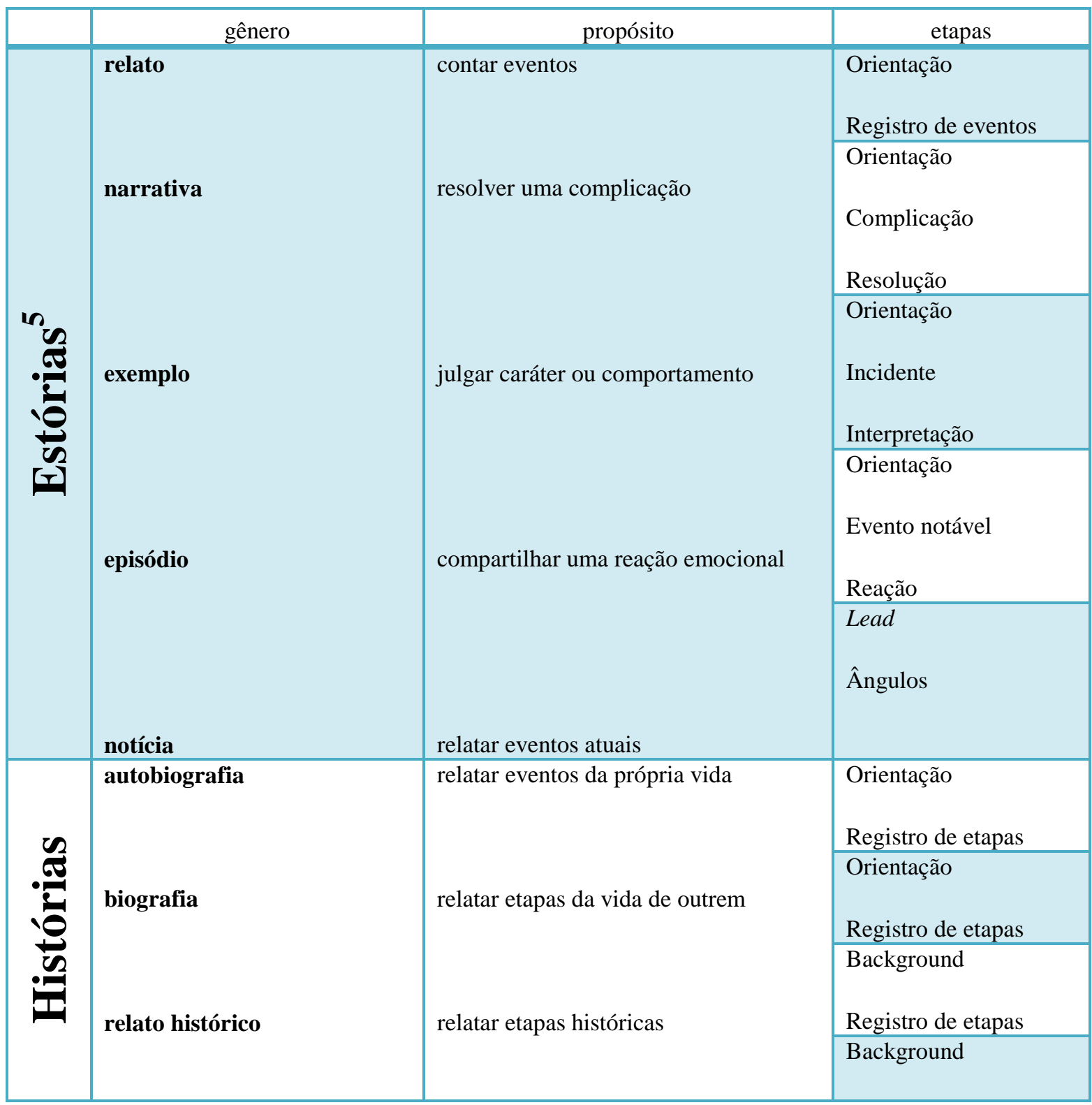

\footnotetext{
${ }^{5}$ No Vocabulário Ortográfico da Língua Portuguesa (VOLP) são apresentadas as palavras História e estória, apesar de muitos estudiosos da língua não concordarem com a diferenciação. Contudo, estória, história, explicações, procedimentos, relatos, argumentos e respostas a textos se tratam de rótulos funcionais criados e utilizados pelos pesquisadores da Escola de Sydney, a fim de diferenciar os gêneros do contexto escolar.
} 


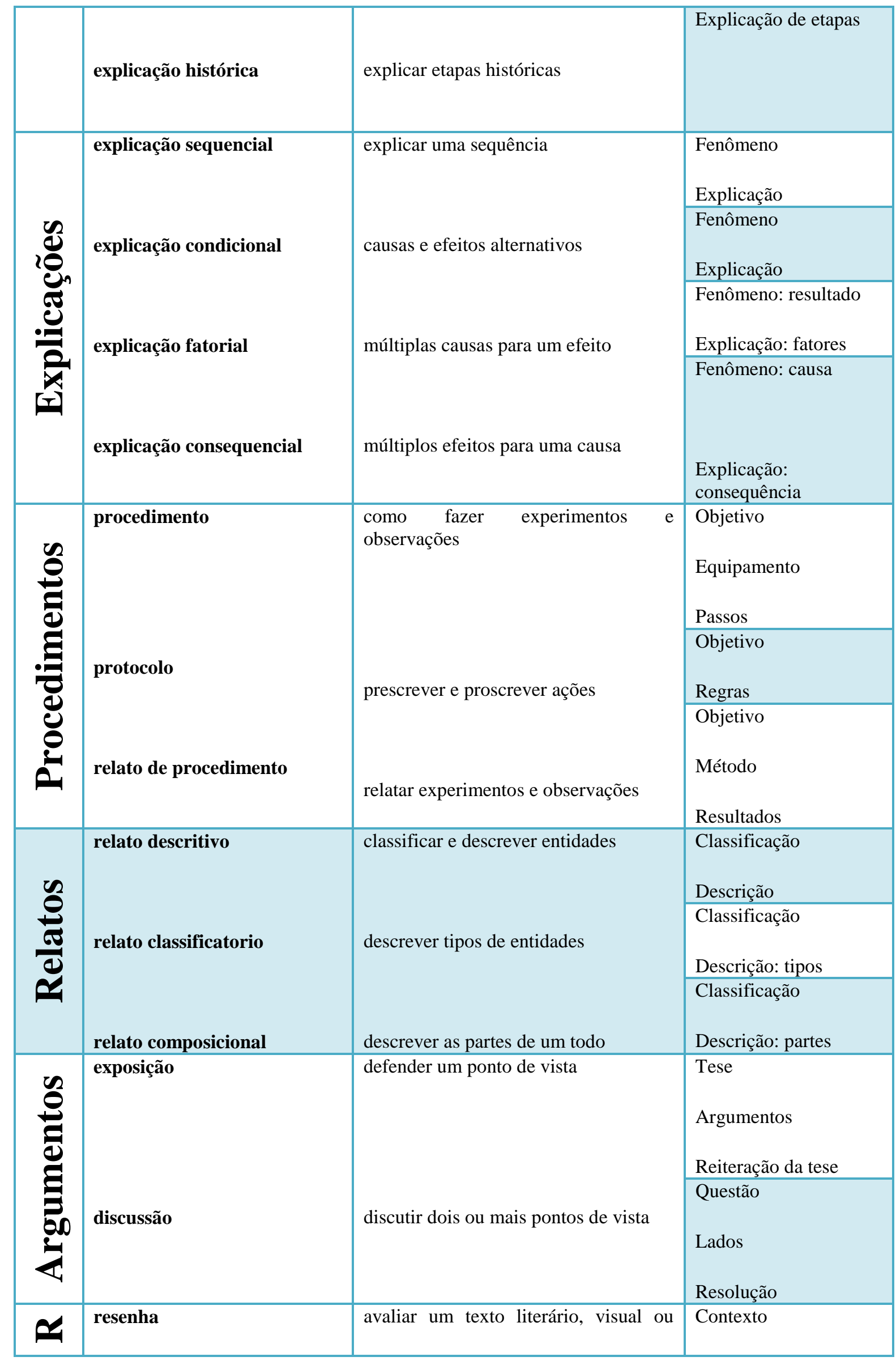




\begin{tabular}{|l|l|l|l|}
\hline \multirow{2}{*}{ interpretação } & musical & Descrição do texto \\
& & Avaliação \\
\cline { 3 - 4 } & interpretar a mensagem de um texto & $\begin{array}{l}\text { Avaliação } \\
\text { Sinopse/descrição do } \\
\text { texto } \\
\text { pessoal }\end{array}$ & Reafirmação \\
\cline { 3 - 4 } & & Avaliação \\
& Reação \\
\hline
\end{tabular}

Fonte: Muniz da Silva (2015)

\subsubsection{Famílias das Histórias}

Segundo Muniz e Silva (2015), os gêneros das Histórias consistem nos seguintes: autobiografia, biografia, relato histórico e explicação histórica.

Como os gêneros são configurados pelas culturas com base nos propósitos sociais e os propósitos dos gêneros de uma mesma família são semelhantes, para identificar os gêneros é necessário identificar as características léxico-gramaticais.

A autobiografia é um gênero escrito, que apresenta relatos de eventos em série (sequências de atividades), podendo ser agrupados em episódios (fases). Os participantes dos eventos são específicos, e os fatos são relatados na primeira pessoa do discurso.

Às 8 almocei. Depois fui à casa de lições para ver as manas. Acontece que estando as manas sem prestar atenção eu lhes adverti e elas me deram as costas: eu lhes dei um soco sem ser de propósito e elas logo se banharam em lágrimas. Retirei-me, dali a pouco veio ter comigo D. Mariana dizendo-me que as Manas estavam chorando e que eu devia fazer as pazes com elas. Não quis. Que Mentira! ${ }^{6}$

Como se verifica no fragmento de autobiografia D. Pedro II, há a presença de uma série de eventos, evidenciando uma sequência de atividades. Esses eventos são representados por processos na primeira pessoa do singular e pronomes pessoais e retos, também de primeira pessoa. No trecho o Imperador faz referência a pessoas específicas, de sua convivência: as manas e D. Mariana.

\footnotetext{
${ }^{6}$ Fragmento de texto autobiográfico produzido por D. Pedro II - retirado do livro As Barbas do Imperador
} 
A biografia é um gênero escrito, que apresenta sequências de atividades, que também podem ser agrupadas em episódios. Os participantes também são específicos, porém, como quem constrói o relato é outra pessoa, há uma mudança linguística: o texto passa de primeira pessoa para terceira pessoa, como se observa no seguinte fragmento:

Filho e neto de camponeses, José Saramago nasceu na aldeia de Azinhaga, província do Ribatejo, no dia 16 de Novembro de 1922, se bem que o registo oficial mencione como data de nascimento o dia 18. Os seus pais emigraram para Lisboa quando ele não havia ainda completado dois anos. A maior parte da sua vida decorreu, portanto, na capital, embora até aos primeiros anos da idade adulta fossem numerosas, e por vezes prolongadas, as suas estadas na aldeia natal. ${ }^{7}$

Comparando a biografia ao relato histórico, pode-se perceber que há duas semelhanças: o uso da terceira pessoa do discurso e as sequências de atividades. Porém essas sequências de atividades deixam de ser mais seriais, para serem mais episódicas. E, segundo Martin e Rose (2008), o que sustenta os episódios são as relações de tempo, construídas linguisticamente pelas circunstâncias temporais. Outra mudança percebida é que os participantes deixam de ser específicos para serem genéricos (países, instituições, grupos).

O general chegou ao Paraguai em novembro de 1866 e encontrou um Exército desfalcado e desanimado. A região era insalubre e o despreparo geral. Além disso, começava a rarear a apresentação de voluntários brasileiros, o obrigou o governo a intensificar o recrutamento obrigatório. ${ }^{8}$

De acordo com Martin e Rose (2008), as pessoas relatam eventos e, às vezes, além de relatar, elas explicam esses eventos; e essa é a grande diferença entre os relatos históricos, cujo propósito é relatar, e as explicações históricas, cujo propósito é relatar, mas também explicar. E, por isso, as relações temporais deixam de ser os elementos estruturantes das orações para darem lugar às relações de causa e consequência, que explicam os fenômenos, conforme se observa no exemplo.

Mas outros fatores influem na industrialização dos países do Sul: a vinda de firmas estrangeiras em busca de mão de obra barata ou de facilidades concedidas pelos governos (isenção de impostos, terrenos, edifícios ou aluguéis com custos bem menores que nos países

\footnotetext{
${ }^{7}$ Fragmento de biografia de José Saramago, retirado do site http://www.josesaramago.org/biografia-josesaramago/

${ }^{8}$ Fragmento de relato histórico - retirado do livro As Barbas do Imperador
} 
desenvolvidos, facilidades para exportar, etc.) ou ainda da perspectiva de enormes ganhos devido a grande mercado consumidor potencial de algumas nações bastante populosas, como China, Índia, Brasil, Indonésia, etc.

Como se verifica, no fragmento acima, é apresentada a explicação acerca dos fatores que contribuíram para a industrialização dos países do Sul.

As explicações, conforme Muniz da Silva (2015),são classificadas em explicação sequencial, explicação condicional, explicação fatorial e explicação consequencial. A sequencial é um tipo de explicação que apresenta uma série de eventos, em que um evento antecedente leva ao seguinte. A explicação condicional apresenta uma sequência de eventos, porém, alguns desses eventos são obrigatórios e outros dependem dos eventos que os antecedem.

Quando há a explicação de um evento que foi provocado por mais de um fator, trata-se de uma explicação fatorial. E, quando há uma explicação sobre um evento que desencadeou várias consequências, trata-se de uma explicação consequencial.

O estudo dos gêneros associado à aprendizagem dos conteúdos determinados pelos currículos de cada disciplina possibilita que o aluno desenvolva a consciência da importância dos textos para interação das pessoas nos diversos eventos sociais conforme pontua Muniz Silva (2015, p. 208) "Em um ensino significativo de letramentos, os textos concretizam gêneros, que constituem atividades sociais concretas. Os gêneros medeiam diferentes padrões de interação e têm determinado formato em razão do papel que exercem nas instituições sociais."

\subsection{TEORIA SEMIÓTICA SOCIAL DA MULTIMODALIDADE}

Para Kress e van Leeuwen (2006), os discursos são construídos para representar a realidade com diversos modos semióticos, que, segundo Kress (2009, p.54), "são recursos socialmente moldados e culturalmente dados para criarem significado. Imagem, escrita, layout, música, gesto, fala, imagem em movimento, trilha sonora são exemplos de modos utilizados na representação e comunicação.” E a análise desses diversos modos semióticos é objeto de estudo da Teoria Semiótica Social da Multimodalidade, que apresenta, com base na Gramática do Design Visual, diversas categorias de análise.

Em relação à teoria, Kress afirma que 
Numa teoria semiótica social qualquer recurso comunicacional tem que cumprir três funções: ser capaz de representar o que se passa no mundo - estados, ações, eventos: a função ideacional; representar as relações sociais das pessoas envolvidas na comunicação: a função interpessoal; E para representá-los como mensagens - entidades textos - coerentes internamente e com seu ambiente: a função textual. Se música ou cor ou layout atender a esses requisitos, eles são modos; se não, então não. (KRESS, 2009, p.59)

Para van Leeuwen, as imagens não são simples reproduções da realidade, pois quem as produz está vinculado a interesses das instituições sociais, logo é possível verificar como os participantes dos discursos são representados, bem como as relações entre participantes na imagem e entre participante e leitor, a fim de identificar as intenções do produtor; e também se pode analisar como a imagem foi construída para causar este ou aquele efeito.

A relevância de um ensino que favoreça a compreensão da composição de imagens reside no fato de a vida contemporânea estar permeada por recursos semióticos, há imagens por todos os lados (outdoors, placas, letreiros, celulares com dezenas de ícones indicando aplicativos). Contudo, no contexto escolar o ensino privilegiado é o da linguagem verbal. Mesmo os livros didáticos, principal instrumento de estudo dos alunos brasileiros, sendo constituídos por textos com grande variedade tipográfica, diversas cores, imagens, gráficos, mapas, normalmente, não há uma exploração de todos esses recursos, fato que pode influenciar a aprendizagem, pois segundo Unsworth

Os recursos da língua são mais apropriados para as representações de relações sequenciais e a construção de distinções categóricas, ao passo que as imagens são mais apropriadas para a representação de relações espaciais e para formulação de quantidades, gradação, mudanças contínuas (UNSWORTH, 2006, p. 55).

Então, levar o aluno a conhecer os diversos modos de significação do mundo, bem como desenvolver as habilidades de compreensão da multimodalidade presente nos livros e em outros recursos, dentro e fora da escola, pode auxiliá-lo a entender que há diversas possibilidades de criação e interpretação de significados.

Inclusive, nos Parâmetros Curriculares Nacionais há a prescrição para a utilização de linguagens múltiplas, conforme se verifica em um dos objetivos gerais para que os alunos do Ensino Fundamental atinjam:

Os Parâmetros Curriculares Nacionais indicam como objetivos do ensino fundamental que os alunos sejam capazes de: 
- utilizar as diferentes linguagens - verbal, musical, matemática, gráfica, plástica e corporal - como meio para produzir, expressar e comunicar suas idéias, interpretar e usufruir das produções culturais, em contextos públicos e privados, atendendo a diferentes intenções e situações de comunicação; (PARÂMETROS CURRICULARES NACIONAIS, 1997, p.55)

Ainda, segundo Vieira (2015),

Os estudos derivados da Teoria Social contribuem para que o sujeito possa incorporar maior poder de discernimento a respeito do mundo multimodal, manifesto principalmente pelos gêneros multimodais, veiculados pelos meios midiáticos circundantes. (VIEIRA, 2015, p. 44)

Ou seja, o conhecimento da Teoria Semiótica Social da Multimodalidade além de dar suporte para análises sistematizadas de imagens e recursos multimodais, pode empoderar aqueles que a conhecem, pois essa teoria oferece subsídios para a percepção de como os diversos modos semióticos são organizados para a representação do mundo e das relações. Logo, o ensino explícito da multimodalidade pode acrescentar bastante na educação de crianças e jovens.

Kress e van Leeuwen (2006), por acreditarem que as imagens e os textos multimodais também possuem as funções de representação das experiências do mundo, de representação das relações e de organização dos elementos constituintes do modo para que tenha finalidade, adaptaram as metafunções da linguagem verbal para a linguagem visual e criaram categorias de descrição de análise.

O ponto de partida para a multimodalidade é estender a interpretação social da linguagem e seus significados a toda a gama de modos representacionais e comunicacionais ou recursos semióticos para fazer sentido que são empregados em uma cultura - como imagem, escrita, gesto, olhar, fala, postura. (JEWITT, 2011, p.01)

\subsubsection{Representação}

Em relação à função de representação das experiências do mundo físico e do mundo da consciência, a linguagem visual pode ser dividida em duas categorias: das imagens narrativas, nas quais eventos ocorridos em um determinado tempo e um determinado espaço são representados; e das imagens conceituais, cujas funções são a representação de identidades e atributos dos participantes.

\subsubsection{Narrativas}


Nas imagens narrativas, há a representação de eventos em que participantes estão envolvidos; as circunstâncias de tempo e lugar podem ser notadas, inclusive com a presença de participantes ao fundo; há a presença de vetores ${ }^{9}$, e os processos usados para as representações são os de ação, de reação, mental e verbal.

As representações narrativas de ação, quando apresentam um ou mais participantes interagindo, são classificadas como transacionais. Quando apresentam apenas um participante, recebem a classificação de não-transacionais. Nesses casos, os vetores podem ser partes do corpo que se conectam ou outros elementos que estabelecem ligações ${ }^{10}$. As representações de reações também podem ser classificadas em transacionais ou em nãotransacionais, contudo nesses casos, o vetor é sempre a linha do olhar do participante ou dos participantes. É transacional quando o elemento motivador do olhar do participante está representado, e é não-transacional quando esse elemento não está representado, deixando a possibilidade de interpretação para o leitor.

Quando imagens são representadas com balões de fala e balões de pensamentos, há respectivamente processos verbais e processos mentais.

\subsubsection{Conceituais}

Assim como os processos relacionais e seus participantes, as imagens conceituais representam as identidades e atributos dos participantes, que, são representados em grupos, pois o foco está na relação parte/todo. Nesse tipo de representação, não há a presença de vetores, o detalhamento do pano de fundo é mínimo ou inexistente, e os processos que realizam essas representações são os classificatórios, os analíticos e os simbólicos.

Os participantes - apresentados em grupo -, nas imagens constituídas por processos classificatórios fazem parte de um todo e suas características podem ser percebidas, de forma explícita, quando há legenda, ou de forma implícita, quando não há a presença de legenda. Os processos analíticos estão relacionados ao destaque que é dado a uma parte de algo. E os processos simbólicos representam os elementos que foram destacados ou forjados na imagem para agregar-lhe valor, por meio de uma iluminação diferenciada ou por meio de uma coloração única, como sépia.

\subsubsection{Interação}

Assim como nos textos verbais, pode-se perceber as relações entre os participantes no texto e entre o produtor e o leitor, nos textos constituídos por linguagem visual isso também é

\footnotetext{
${ }^{9} \mathrm{Na}$ linguagem visual, os vetores são como os processos na linguagem verbal, ou seja, indicam as ações.

${ }^{10}$ De acordo com Kress e van Leeuwen (2006, p.46), “o que na linguagem é realizado por palavras da categoria "verbos de ação" é visualmente realizado por elementos que podem ser formalmente definidos como vetores.
} 
possível. E para identificar essas relações, pode-se observar, a princípio, se o contato entre o participante e o leitor é pessoal ou impessoal. Isto é, se o participante tem o olhar registrado direcionado para o leitor, esse contato é mais pessoal e representa uma demanda do participante. Mas, se o contrário ocorre, ou seja, se o participante não está com o olhar conectado ao leitor, esse contato é classificado como impessoal e, nesse caso, ocorre a oferta de um sentimento, de uma ação, de uma relação.

Depois, pode-se verificar a distância social com base no plano fechado, conhecido como close-up, que representa um maior vínculo entre participante e leitor; no plano médio, ou médium shot, onde há a representação de vínculo puramente social; e o plano aberto, em que os participantes são representados distantes e por isso o vínculo com o leitor é bem impessoal.

Logo após, a atitude do participante pode ser analisada com base no posicionamento de seu corpo. Se o corpo está de frente, cria um envolvimento maior com o leitor, mas se o participante é retratado de lado, representa um certo distanciamento, e, se o participante é registrado de costas, a atitude pode ser interpretada como de grande distanciamento.

Por fim, o poder do participante retratado pode ser analisado com base no ângulo, pois se a imagem retrata como se o participante estivesse acima do leitor, trata-se de um ângulo alto e significa superioridade do participante em relação ao leitor. Contudo, se o ângulo registrado está no nível do olhar do participante, há uma igualdade de poder entre participante e leitor. E, se o ângulo utilizado foi o baixo, denota maior poder do participante em relação ao leitor.

\subsubsection{Composição}

Para a função de composição, Kress e van Leeuwen criaram as categorias de valor da informação, enquadramento e saliência. Porém, é importante pontuar que os estudos que desenvolveram estão relacionados a imagens e a textos multimodais pertencentes à cultura ocidental. Logo, essas categorias de análise não podem ser imediatamente transpostas para descrição de textos multimodais produzidos em uma cultura oriental, pois pode se tratar de outras formas de disposição dos elementos para composição desses textos.

Considerando uma linha imaginária que corta a imagem ao meio, de cima para baixo, aquilo que é apresentado à esquerda é a informação conhecida, que é chamada de dado; e o que está à direita é a informação nova. Então, com base nessa disposição, as informações que 
não são novidades são dispostas no lado esquerdo e as informações novas são dispostas no lado direito. Também pode-se imaginar uma linha que divida a imagem da esquerda para a direita, e as informações posicionadas na parte de cima, chamada de topo, estão relacionadas àquilo que é imaginário ou ideal; e na parte inferior, chamada de base, são apresentadas as informações relativas ao que é real. E um exemplo disso é a publicidade de algum produto, cujas informações idealizadas normalmente estão no topo, e na base encontram-se as informações técnicas. Ainda, ao observar a distribuição das informações, as mais importantes apresentam-se ao centro e as complementares apresentam-se nas margens. Assim, verificando a disposição das informações com base em dado - novo, ideal - real e centro - margens, uma observação acerca do valor da informação está em curso.

Outro aspecto a ser considerado na função de composição da linguagem visual é o enquadramento. Para Kress (2009, p.66), assim como os textos verbais possuem enquadramentos definidos pela pontuação, que limita o que fica dentro da oração (enquadramento), ou do período, ou do parágrafo (outros tipos de enquadramento); as imagens também são retratadas com elementos interligados, elementos separados e elementos segregados, o que implica significados diferentes na distribuição das informações.

A saliência é mais um aspecto a ser observado nas análises, pois intencionalmente alguns recursos são utilizados para tornar uma informação mais saliente que outras, como a variação no tamanho de algum elemento, tornando-o maior ou menor do que realmente é; a coordenação de cores, em que algumas cores, propositalmente, podem receber destaque a fim de criar alguma reação no leitor; e a distribuição de informações em primeiro, segundo e até mais planos, situações na quais se privilegia uma informação em relação à outra.

\subsubsection{Relações entre os modos}

Unsworth (2006) reflete acerca da necessidade de pedagogias de letramentos multimodais e reforça que é preciso desenvolver a compreensão dos significados intramodais, isto é, descrever as características específicas de cada modo semiótico e sua organização para a construção dos sentidos; e desenvolver a compreensão dos significados intermodais, ou seja, a compreensão dos significados que se encontram na intersecção entre os modos. Assim, apresenta dados de investigações de diversos sistêmicos funcionais que combinam categorias de análises da GSF e da GDV para demonstrar como esses pesquisadores (Kress e van Leeuwen, 1996; Royce, 1998; Gill, 2002; Lemke, 2002; Martin, 2002; Cheong, 2004; Lim, 
2004; Martinec e Salway, 2005) descrevem e formulam uma metalinguagem para os multiletramentos.

Sintetizando esses estudos, Unsworth (2006) afirma que, em termos de significado ideacional, a interação entre os modos pode ocorrer por meio de concordância ideacional, complementaridade ou conexão.

Primeiramente, a concordância ocorre quando há equivalência entre imagem e língua, ou seja, o modo verbal e o modo visual são constituídos pelos mesmos participantes e pelos mesmos processos, conforme se verifica na figura a seguir.

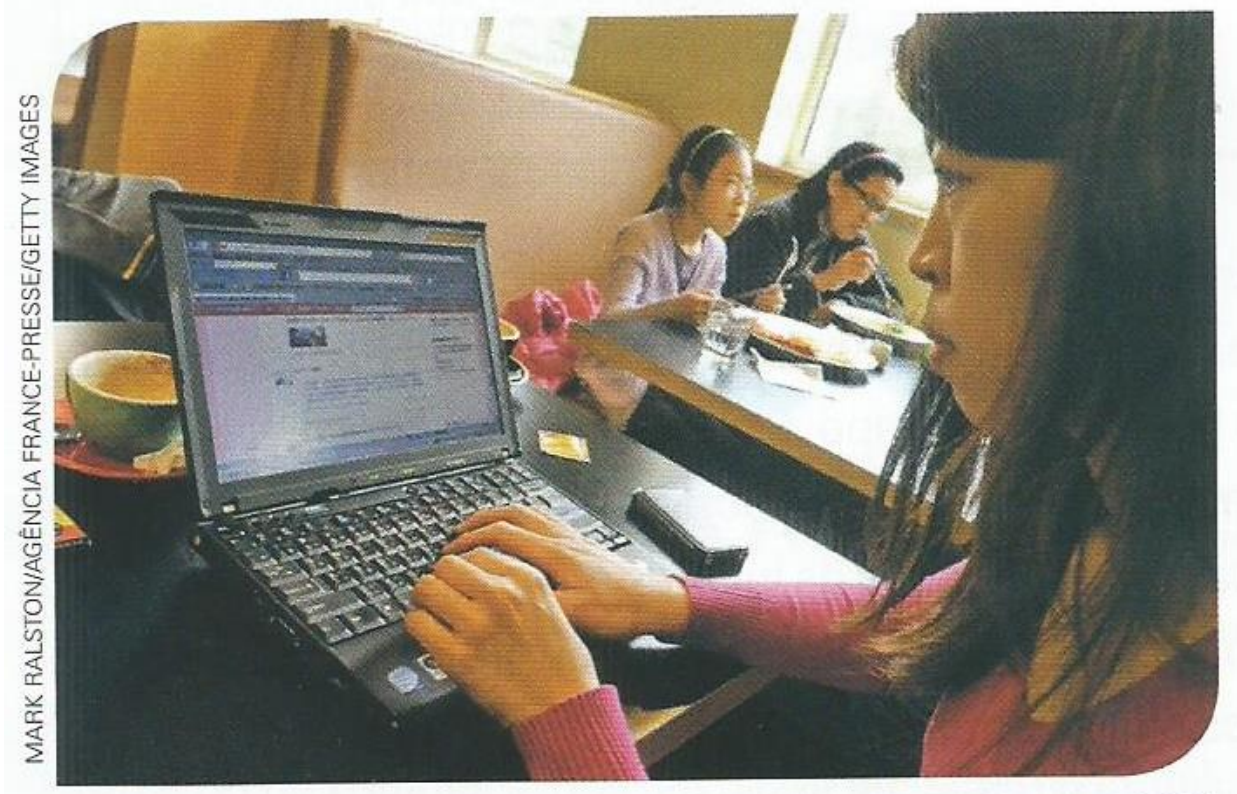

Mulher acessando a internet em um café, em Pequim, na China, em 2012.

Figura 5: Imagem e legenda presentes em livro Projeto Teláris.

Fonte: Livro Projeto Teláris $-9^{\circ}$ ano

Porém, a concordância pode ser relativa, pois há possibilidade do texto ser uma instância da imagem, quando o texto informa apenas um parte do significado apresentado na imagem; ou o contrário, a imagem ser uma instância do texto, isto é, representar um momento de toda a cena narrada. E outra forma de concordância é a homoespacialidade, que consiste nos modos verbal e visual estarem representados no mesmo espaço, como ocorre na figura a seguir. 


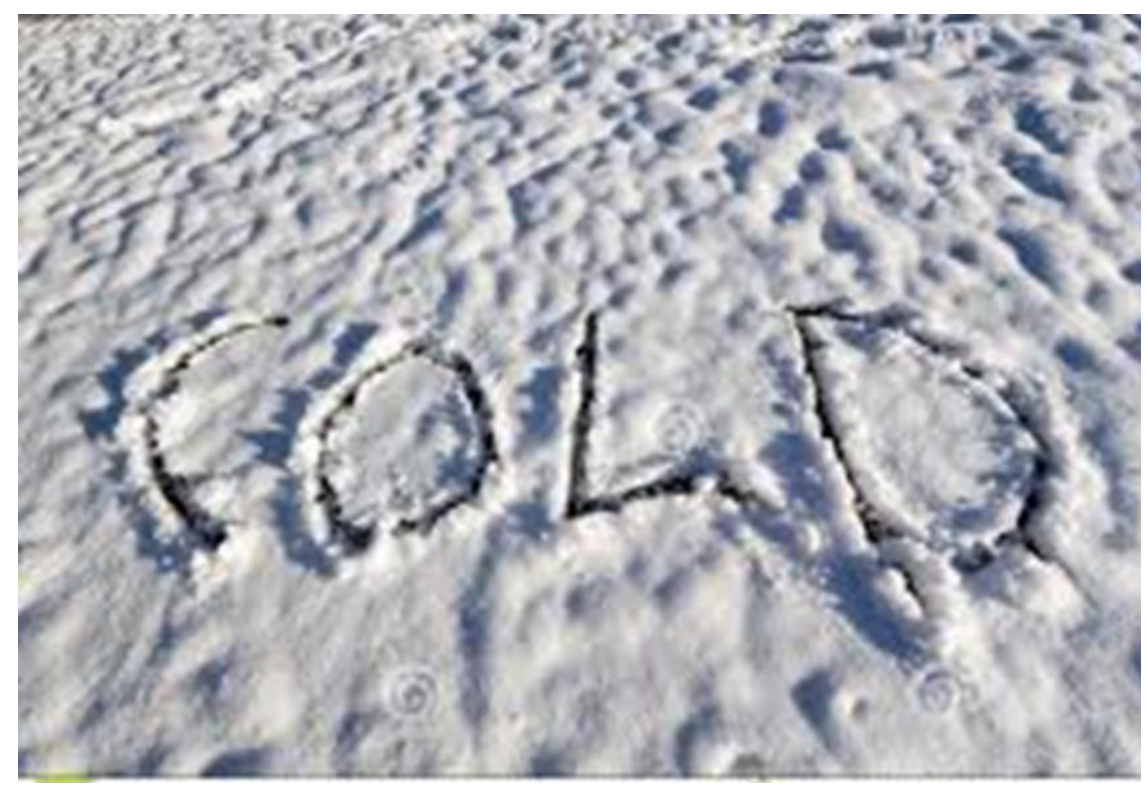

Figura 6: Homoespacialidade.

Fonte: internet

A complementaridade ideacional refere-se à situação em que o que é representado nas imagens e o que é representado na língua podem ser diferentes, mas complementares, contribuindo conjuntamente para um significado global que é mais do que os significados transmitidos pelos modos separados. Ela pode ocorrer por acréscimo ou por divergência. Quando é por acréscimo, ora a imagem pode acrescentar significado ao que foi escrito, ora o texto verbal pode acrescentar significado ao que foi representado visualmente. E, quando ocorre divergência, os modos semióticos parecem que são opostos.

Por fim, a conexão que ocorre entre imagem e língua pode ser por projeção - quando há representação de fala ou pensamento -, e por conjunção - quando são representadas relações causais, temporais ou espaciais.

Então, os tipos de relações estabelecidas pela intersecção dos modos visuais e escritos podem ser sintetizados da seguinte forma 


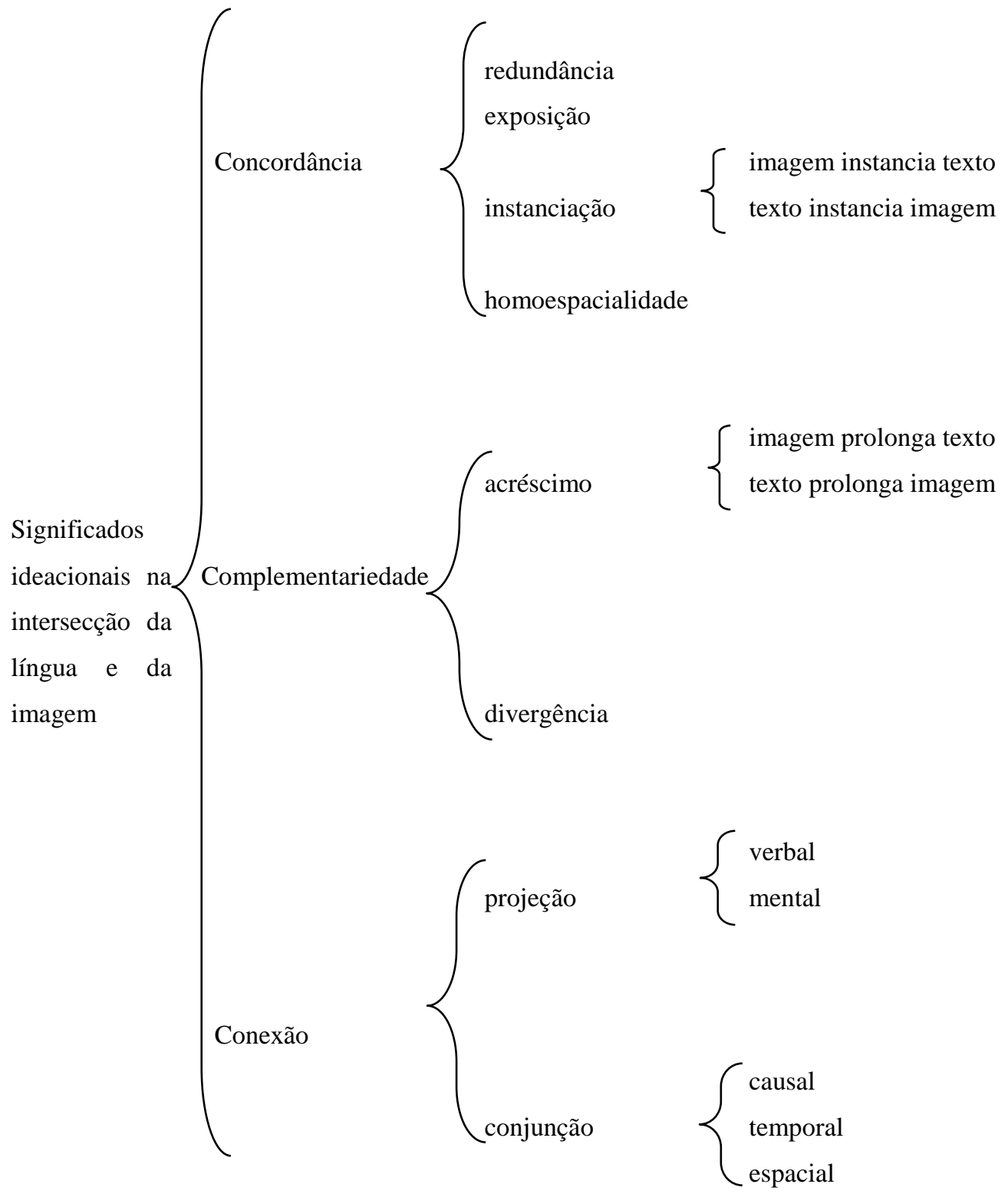

Figura 7: Relações entre os modos.

Fonte: Unsworth, 2006 
Considerações

A utilização de arcabouços teóricos é imprescindível para a sustentação de uma pesquisa, assim como, se mais de uma teoria é empregada em uma pesquisa, que estejam em consonância para que não haja divergências nas análises dos dados. Assim, a Gramática Sistêmico Funcional, a Teoria de Gêneros da Escola de Sydney e a Teoria Semiótica Social da Multimodalidade cumprem esse requisito, pois compartilham o mesmo conceito de que a linguagem cumpre três metafunções: representa os acontecimentos do mundo, representa as relações entre os participantes dos acontecimentos e organiza as informações acerca dessas representações. Também comungam o princípio de que para a análise dos textos, devem ser considerados dois contextos: o de situação, que determina as escolhas léxico-gramaticais e o de cultura, que determina as escolhas dos gêneros, que são configurações recorrentes de significados compartilhados por pessoas de um cultura, para atingir propósitos sociais.

Logo, descrever e analisar os gêneros presentes nos livros didáticos de Geografia sob as lentes da GSF, da TGES e da TSSM, pode contribuir para a compreensão de quais gêneros textuais, visuais ou multimodais são utilizados e de que forma a relação entre eles representam os eventos e seus participantes, representam as relações entre os participantes e entre autores e leitores e organizam as informações. 


\section{CAPÍTULO 2 - CAPÍTULO METODOLÓGICO}

\section{INTRODUÇÃO}

$\mathrm{O}$ objetivo neste capítulo é apresentar o desenho metodológico desta pesquisa. $\mathrm{Na}$ seção 3.1 são apresentadas as características gerais deste estudo. Em seguida, nas seções 3.2, 3.3, 3.4 e 3.5 são apresentadas as classificações desta pesquisa. Na seção 3.6 a delimitação do corpus é apresentada, explicitando como foi definido e as dificuldades que foram encontradas para a coleta dos dados. Na seção 3.7, as questões de pesquisa são descritas e na seção 3.8, há a descrição do corpora, primeiro de forma geral, depois, utilizando as categorias de análise da Gramática Sistêmico Funcional, que auxiliaram na delimitação dos recursos léxicogramaticais recorrentes, que, por sua vez, auxiliaram na descrição dos gêneros textuais.

\subsection{DELINEAMENTO METODOLÓGICO}

O delineamento metodológico de uma pesquisa inicia com a definição dos tipos de dados que serão coletados ou gerados, e com os métodos que serão utilizados para análise desses dados. E, como os dados desta pesquisa são textos, representações do mundo, dos participantes que nele vivem e dos eventos que nele ocorrem, pode-se afirmar que esta pesquisa é social, com abordagem qualitativa. Em relação aos objetivos, a pesquisa é descritiva; e, em relação aos procedimentos, é documental.

\subsection{PESQUISA SOCIAL}

As pesquisas sociais objetivam, com base em questões de pesquisa, em dados coletados ou gerados por métodos empíricos e nas análises dos dados, encontrar respostas para os questionamentos sociais. E tais respostas muitas vezes contribuem para tomadas de decisão que podem culminar em políticas públicas e outras resoluções de problemas.

Bauer e Gaskell afirmam que

O mundo, como o conhecemos e o experienciamos, isto é, o mundo
representado e não o mundo em si mesmo, é constituído através de
processos de comunicação (Berger \& Luckmann, 1979; Luckmann,
1995). A pesquisa social, portanto, apoia-se em dados sociais - dados
sobre o mundo social - que são o resultado, e são construídos nos
processos de comunicação. (BAUER E GASKELL, 2005, p. 20)

Assim, as formas como representamos o mundo nos processos comunicativos são os dados sociais. Ainda, segundo os autores, há dois modos de dados sociais e três meios através dos quais esses dados são construídos. Os modos são a comunicação informal, por meio de entrevistas, pois não exige tantas formalidades e regras; e comunicação formal, na qual se 
exigem formalidade e conhecimento mais especializado do autor. Os meios são os textos, as imagens e os materiais sonoros.

Nesta pesquisa, na qual se objetiva descrever os dados que compõem partes de livros didáticos de Geografia a fim de descobrir padrões de constituição desses livros; textos e imagens foram descritos e analisados com base nas metodologias de análise da Gramática Sistêmico Funcional, da Teoria de Gêneros da Escola de Sydney e da Teoria Semiótica Social da Multimodalidade.

\subsection{PESQUISA QUALITATIVA}

Segundo Bauer e Gaskell (2005), têm ocorrido diversas discussões acerca dos elementos que distanciam a pesquisa com abordagem qualitativa da pesquisa com abordagem quantitativa. Enquanto aquela trata de interpretações das realidades encontradas em textos coletados em entrevistas, esta lida com análises estatísticas de dados numéricos coletados em levantamentos (survey), logo, aquela é considerada soft, e esta, hard. Contudo, a fim de encontrar o ponto de intersecção entre as duas abordagens, afirmam que não há quantificação sem qualificação, ou seja, é necessário o conhecimento das categorias para depois quantificálas. Também afirmam que não há análise estatística sem interpretação, isto é, os números não carregam todas as informações, logo precisam ser interpretados.

Desse modo, ainda que, em determinado momento, tenha ocorrido a quantificação de resultados das análises para determinação de padrões linguísticos nos textos investigados e demonstrados, esta pesquisa se classifica em relação à abordagem, como qualitativa que, segundo Denzin e Lincoln

[...]é uma atividade situada que localiza o observador no mundo. Consiste em um conjunto de práticas materiais e interpretativas que dão visibilidade ao mundo. Essas práticas transformam o mundo em uma série de representações, incluindo as notas de campo, as entrevistas, as conversas, as fotografias, as gravações e os lembretes. (DENZIN E LINCOLN, 2003, p. 17)

\subsection{PESQUISA DESCRITIVA}

A pesquisa, do ponto de vista do objetivo, pode ser classificada em teórica, descritiva ou explicativa. E o que determina a definição do objetivo geral é a questão de pesquisa, que neste estudo está relacionada à descoberta dos gêneros presentes nos livros didáticos de Geografia. Portanto, como o que está em questão se refere à identificação de características léxico-gramaticais para classificação dos gêneros, há a necessidade de descrição dos textos. 


\subsection{PESQUISA DOCUMENTAL}

Em relação aos procedimentos, a pesquisa pode ser classificada como pesquisa bibliográfica, participante, pesquisa ex-post-facto, pesquisa ação, estudo de caso e pesquisa documental. E, como, neste momento, não é relevante discorrer sobre todos os tipos de procedimentos citados, tratarei brevemente daquele que faz parte da caracterização dessa pesquisa, a pesquisa documental, para logo após descrever os objetos de pesquisa.

Em um encontro do grupo brasileiro do Projeto Systemics Across Languages (SAL), em abril de 2015, na Pontifícia Universidade Católica de São Paulo (PUC), os pesquisadores presentes decidiram que, para a compreensão dos gêneros que são ensinados nas escolas brasileiras, havia a necessidade de investigação dos materiais utilizados, entre eles, os livros didáticos adotados. Assim, propus-me a investigar os livros do componente curricular Geografia, uma disciplina de grande relevância, pois o estudo dos conteúdos que a constituem pode contribuir para que os estudantes percebam a importância do espaço geográfico para eles e para a sociedade da qual fazem parte. Soma-se a isso que, dependendo de como os temas são desenvolvidos, podem fornecer dados, informações para que os alunos façam uma análise crítica da realidade e percebam as ideologias por trás das escolhas que foram feitas para a construção dos textos.

Uma das políticas públicas mais antigas na Educação brasileira é a de distribuição de livros didáticos. Desde 1929, quando foi iniciada, até os dias atuais, já teve vários nomes e diversas configurações. Hoje, denominada Programa Nacional do Livro Didático (PNLD), constitui um processo rigoroso de seleção de material pedagógico, distribuído aos estudantes da rede pública das cinco regiões brasileiras - livro didático -, e aos seus professores Manual do Professor. No momento em que delimitei a escolha, o programa vigente para o Ensino Fundamental era o PNLD 2014, cujos livros deveriam ser adotados e utilizados no triênio de 2014, 2015 e 2016.

Apesar de conhecer o processo de escolha dos livros na perspectiva de professora, no portal Fundo Nacional de Desenvolvimento da Educação (FNDE), pude pesquisar e encontrar informações acerca dos editais, que estabelecem pré-requisitos para participação das editoras, prazos para inscrição das coleções e para entrega delas, além de critérios e especificações técnicas. Também tive acesso ao Guia do livro Didático, que apresenta resenhas das coleções escolhidas, que foram elaboradas por especialistas que analisaram os livros inscritos no 
processo; além disso, acessei os dados estatísticos, entre eles, a quantidade de livros didáticos de cada coleção distribuídos.

Na busca por informações, outro problema com o qual me deparei foi a quantidade de livros, pois, das 30 coleções de Geografia inscritas para o PNLD 2014, sete foram excluídas, por estarem fora dos critérios estabelecidos pelo Edital de Convocação para o processo de inscrição e avaliação de coleções didáticas para o Programa Nacional do Livro Didático (PNLD 2014). Entretanto, vinte e três coleções ainda é um número vultoso para uma investigação no curso de mestrado, logo urgia a delimitação do corpus. Desse modo, considerando que os conteúdos de Geografia nos primeiros anos do Ensino Fundamental estão mais relacionados à geografia física, isto é, trata da descrição da terra, concentrada em especificações acerca dos tipos de solos, de relevos, de climas, rios; optei pela análise de livros de nono ano do Ensino Fundamental, por tratarem mais de temas relativos à Geografia Humana.

Outra decisão que tive que tomar foi a respeito de quantos livros analisaria. A princípio, estava propensa a escolher um único livro, descrevê-lo e identificar padrões. Contudo, a análise de um capítulo de livro para participação em um evento de Linguística, auxiliou-me a tomar a decisão de fazer um estudo comparado, pois a análise feita em apenas um livro proporcionaria a descoberta de padrões naquele livro, mas estariam mais relacionados à metafunção interpesssoal - escolhas do(s) autor (es) . E fazendo uma análise comparada entre obras, poderia encontrar padrões não só relacionados à metafunção interpessoal, como aqueles relacionados às metafunções ideacionais e textuais, isto é, relativos às três variáveis de registro, respectivamente, relações, campo e modo. Assim, defini como objeto de análise os três livros de Geografia mais adotados, no PNLD 2014, para os alunos do nono ano do Ensino Fundamental.

Wolff (2004b apud FLICK, 2009, p. 231) afirma que "Documentos são artefatos padronizados na medida em que ocorrem tipicamente em determinados formatos como: notas, relatórios de caso, contratos, rascunhos, certidões de óbito, anotações, diários, estatísticas, certidões, sentenças, cartas ou pareceres de especialistas.” Logo, os livros didáticos, que seguem padrões e tipicamente apresentam-se com o mesmo formato, especialmente aqueles que são aprovados pelo PNLD, devido à necessidade de estarem em plena concordância com os diversos critérios estabelecidos em edital, podem ser classificados como documentos. 
Segundo Scott (1990 apud FLICK, p. 233), a qualidade dos documentos pode ser avaliada por meio da autenticidade, da credibilidade, da representatividade e da significação. Então, com base nesses quatro critérios, posso afirmar que os livros que delimitei para análise tratam-se de documentos com qualidade, pois são autênticos, visto que passam por controle rígido de seleção e portam diversas características relativas à estrutura editorial - informações que, obrigatoriamente, devem constar na capa, na segunda capa, na folha de rosto, na contra capa - e às especificações técnicas, como formato, matéria prima e acabamento. Os livros apresentam credibilidade, porque foram submetidos a uma avaliação criteriosa empreendida por comissão composta por especialistas, convidada pelo MEC para avaliá-los, não só em relação à qualidade gráfica, mas principalmente em relação aos conteúdos que os constituem conforme se constata nos critérios gerais apresentados no Guia do Livro Didático ${ }^{11}$

1. respeito à legislação, às diretrizes e às normas oficiais relativas ao ensino fundamental;

2. observância de princípios éticos necessários à construção da cidadania e ao convívio social republicano;

3. coerência e adequação da abordagem teórico-metodológica assumida pela coleção, no que diz respeito à proposta didático-pedagógica explicitada e aos objetivos visados;

4. correção e atualização de conceitos, informações e procedimentos;

5. observância das características e finalidades específicas do Manual do Professor e adequação da coleção à linha pedagógica nele apresentada;

6. adequação da estrutura editorial e do projeto gráfico aos objetivos didáticopedagógicos da coleção. (MINISTÉRIO DA EDUCAÇÃO, 2012, p. 8)

São representativos, porque são típicos do seu tipo, isto é, apresentam todas as características que um livro didático deve ter; e também são dotados de significação, visto que possuem todos os elementos para construir a significação a que se propõem.

Scott (1990 apud FLICK, p. 231) distingue doze tipos de documentos combinando duas dimensões: autoria e acesso, conforme esquema apresentado na figura 8. E, com base nestas combinações de critérios posso classificar os livros didáticos, objetos deste estudo, quanto à autoria, como oficial público, e quanto ao acesso, como publicação aberta.

\footnotetext{
${ }^{11}$ Material disponibilizado para os professores contendo resenhas elaboradas por pesquisadores que avaliaram o conteúdo dos livros didáticos inscritos no PNLD.
} 


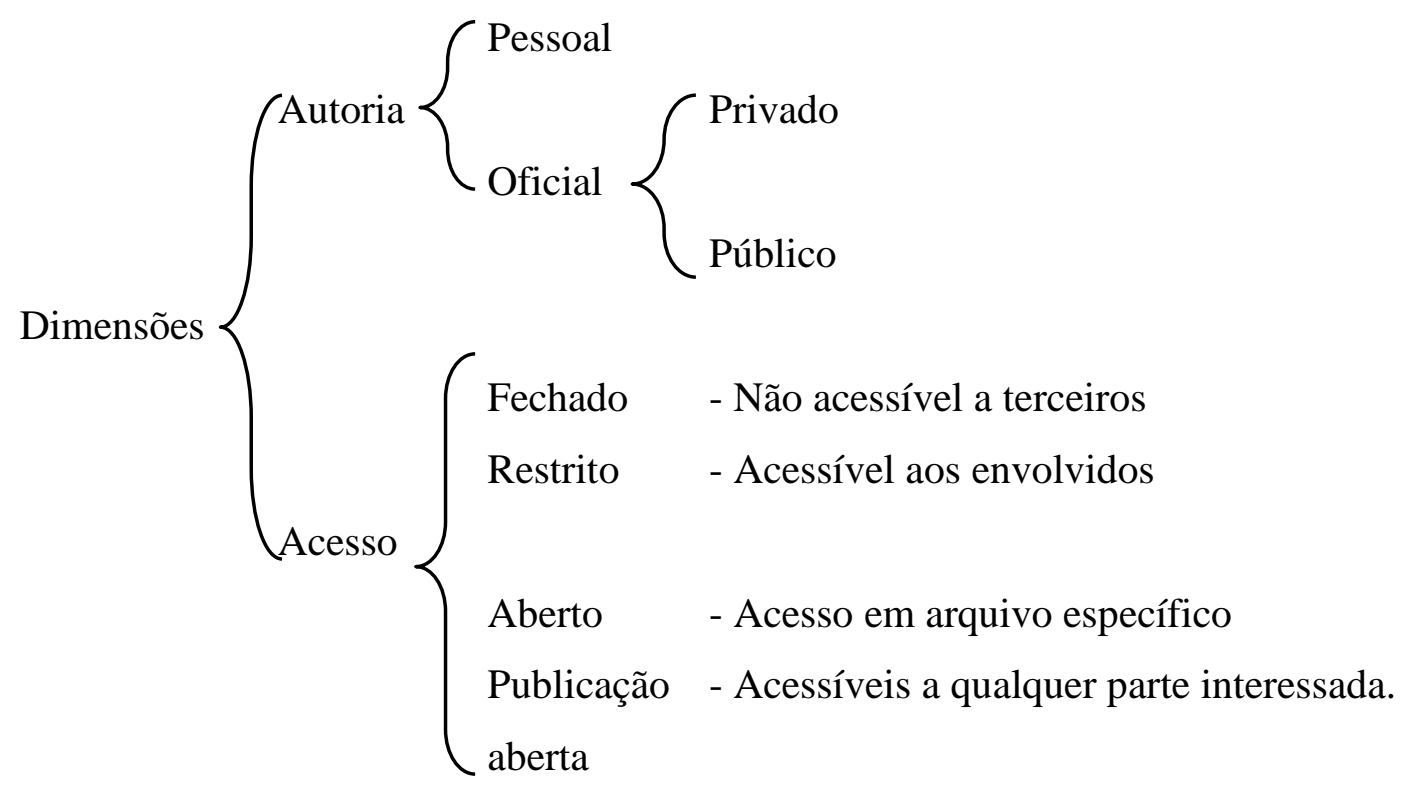

Figura 8: Taxonomização dos documentos

Fonte: elaborada pela autora com base em Scott (1990 apud FLICK)

Flick (2009) afirma que a vantagem da utilização de documentos como dados em uma pesquisa reside no fato de desenvolver investigação relacionada a um campo específico, contudo, com um método não-intrusivo. Além disso, reforça que, ao analisar documentos, não se deve observar apenas os elementos contidos neles, ou seja, deve-se considerar o contexto de produção, refletindo sobre quem produziu o documento, com que objetivo produziu, para quem produziu e quais as intenções ao produzi-lo; o que vai ao encontro das teorias utilizadas nesta pesquisa, pois consideram que o texto é fruto de uma cultura, logo, ao analisá-los podemos identificar características dessa cultura.

\subsection{DELIMITAÇÃO DO CORPORA}

Os exemplares escolhidos para análise são: Projeto Araribá, da editora Moderna, com 749.469 unidades distribuídas; Expedições Geográficas, também da editora Moderna, com 394.512 distribuídas e Projeto Teláris, da editora Ática, com 244.686 unidades distribuídas. Somando esses três livros mais adotados, o resultado obtido é de 1.388 .667 unidades, o que corresponde a 48\% dos quase 2.800.000 livros de Geografia distribuídos, pelo Programa Nacional do Livro Didático de 2014, aos alunos de nono ano. Os dois primeiros livros didáticos mais adotados são da mesma editora, porém, são de autores distintos; e o terceiro é um projeto de outra editora. Dessa forma, analisando essas três amostras individualmente e depois comparando-as, poderíamos encontrar configurações comuns, gêneros recorrentes, estruturas semelhantes, padrões léxico-gramaticais entre eles. 
Após a definição dos três livros, fiz um recorte temático, selecionando o capítulo de cada livro que introduzia o tema Globalização. Tal escolha deve-se ao destaque dado ao tema dentro dos PCNs (será tratado nas discussões) e dentro dos próprios livros didáticos, já que quase todos os outros subtemas estão relacionados às causas ou às consequências da Globalização.

Conseguir os livros para descrição e análise não foi tarefa fácil. Entrei em contato por telefone com as editoras e nada consegui. Também telefonei para o Ministério da Educação, visando com essa ação receber orientações de como proceder, e a informação que obtive foi que deveria solicitar os volumes nas editoras ou na Secretaria de Educação. Então, fui às editoras e em uma delas recebi o exemplar do Projeto Teláris. Para conseguir os outros livros, liguei na Secretaria de Educação e em uma coordenação Regional de Ensino. Como meus telefonemas não foram exitosos, decidi solicitar a amigos e colegas que trabalhavam em escolas. Também não consegui os materiais assim. Em mais uma tentativa, empreendi busca em quatro escolas públicas localizadas na cidade em que resido, e ainda que professores e 'bibliotecários" ${ }^{12}$ tenham sido muito atenciosos e prestativos, só consegui o livro Expedições Geográficas, mas do PNLD $2017^{13}$. E, após tantas tentativas infrutíferas de obtenção dos livros, decidi comprar em uma loja virtual de livros novos e usados, apesar desses livros serem custeados pelo Estado - não podem ser vendidos, porque são distribuídos gratuitamente pelo Ministério da Educação.

\subsection{QUESTÕES DE PESQUISA}

As questões de pesquisa determinam a definição dos objetivos, a busca pelos dados e as análises. Assim, são definidas no início da pesquisa. Contudo, em uma pesquisa qualitativa, pode-se modificá-las à medida que os dados apontam outros caminhos. E neste caso acabei incluindo a categoria das nominalizações, nas análises, em virtude da frequente ocorrência desse tipo de metáfora gramatical nos três capítulos analisados.

Desse modo, com o propósito de investigar os livros didáticos para atingir o principal objetivo deste trabalho científico, orientei-me pelas questões que se seguem:

2.7.1 Quais os gêneros presentes nos livros didáticos de Geografia?

\footnotetext{
${ }^{12}$ A expressão bibliotecários aparece entre aspas, pois, na maioria das escolas públicas do Distrito Federal, a função de bibliotecário é exercida por um professor ou um servidor da carreira assistência que, normalmente, por motivos de saúde foram afastados de suas funções.

${ }^{13}$ Os livros, de um programa para outro, têm poucas alterações, mas as têm.
} 
2.7.2 Quais os propósitos sociais dos gêneros presentes nos livros didáticos de Geografia?

2.7.3 Como as características léxico-gramaticais são organizadas para representação dos eventos e das relações?

2.7.4 Quantos modos semióticos, além do verbal, compõem o livro didático de Geografia?

2.7.5 Como a relação entre os modos semióticos constroem os significados?

\subsection{DESCRIÇÃO DO CORPORA}

Inicialmente a observação do livro Projeto Teláris foi para conhecer a organização das informações do livro - modo - verificando a quantidade de páginas e de capítulos que o constitui. Também observei as seções que compõem cada capítulo. Os títulos, as fontes, as cores e as imagens não foram ignorados. O capítulo que inicia o tema Globalização é o $12^{\circ}$, que está dentro da quarta e última unidade do livro. O capítulo é composto de uma página de abertura do capítulo, com indicação do número do capítulo, o título do capítulo - Da Divisão Internacional do Trabalho à globalização -, uma frase inicial, uma imagem - foto - e quatro perguntas motivadoras. Nas páginas subsequentes, o texto produzido pelos autores do livro, que estrutura o capítulo; há duas ocorrências da seção Geolink, constituídas de um texto complementar apresentado dentro de um box , seguido de exercícios; um texto retirado de um site de informações, apresentado dentro de um box; outro texto produzido pelos autores do livro, dentro de um box; duas vezes a seção Texto e Ação, constituídas de perguntas relativas aos textos que as antecedem; um mapa, seis fotografias, uma ilustração, todos seguidos de legendas; duas ocorrências da seção Glossário. Ao final, a seção Para fechar o capítulo inicia com a subseção + Ação, que é constituída de dois textos retirados de sites, um mapa, questões de compreensão e interpretação de ideias contidas nesses textos; depois a subseção De olho na imagem contém uma imagem da capa de um jornal, três textos retirados de sites, uma charge, um quadrinho e perguntas relacionadas a eles. Por fim, na subseção Conexões, há uma tabela retirada de um site, um texto, retirado de outro site e uma letra de música, todos seguidos de questionamentos. 
Quadro 5: Resumo da Constituição do Capítulo Analisado - Projeto Teláris ${ }^{14}$

\begin{tabular}{|c|c|c|c|}
\hline & \multirow{7}{*}{ Abertura do capítulo } & Foto em detalhe; & guindaste; \\
\hline & & Símbolo & @ \\
\hline & & $\begin{array}{l}\text { Indicação do } \\
\text { número do capítulo }\end{array}$ & \\
\hline & & Título do capítulo & $\begin{array}{lr}\text { Divisão } & \\
\text { internacional } & \text { do } \\
\text { Trabalho } & \text { à } \\
\text { globalização } & \end{array}$ \\
\hline & & Declaração Inicial & $\begin{array}{lr}\text { Neste } & \text { Capítulo } \\
\text { vamos conhecer a } & \text { a } \\
\text { Divisão } & \\
\text { Internacional } & \text { do } \\
\text { Trabalho } & \text { (DIT) } \\
\text { desde } & \text { seu } \\
\text { surgimento, } \\
\text { acompanhando suas } \\
\text { mudanças, } \\
\text { adaptações, para } \\
\text { compreender sua } \\
\text { evolução até os dias } \\
\text { de hoje. }\end{array}$ \\
\hline & & Fotografia & $\begin{array}{lr}\text { Porto } & \text { de } \\
\text { Cingapura, } & \text { em } \\
2012 . & \end{array}$ \\
\hline \multirow[b]{3}{*}{ ב̃ } & & Motivação & $\begin{array}{l}\text { quatro perguntas } \\
\text { motivadoras }\end{array}$ \\
\hline & & Texto & dos autores \\
\hline & & $\begin{array}{l}\text { Ilustração } \\
\text { legenda }\end{array}$ & $\begin{array}{l}\text { Concepção } \\
\text { artística de teares } \\
\text { mecânicos com os } \\
\text { quais o Reino } \\
\text { Unido iniciou a } \\
\text { Revolução } \\
\text { Industrial no }\end{array}$ \\
\hline
\end{tabular}

${ }^{14}$ Descrição com base nas informações contidas nas páginas 250-267 do livro de Geografia para o $9^{\circ}$ do ensino fundamental, Projeto Teláris. 


\begin{tabular}{|c|c|c|}
\hline \multirow[t]{3}{*}{1 Divisão Internacional do Trabalho } & & \multirow[b]{2}{*}{$\begin{array}{l}\text { século XVIII. } \\
\text { A Divisão } \\
\text { Internacional do } \\
\text { Trabalho no seu } \\
\text { auge, nos anos } \\
1970 .\end{array}$} \\
\hline & $\begin{array}{l}\text { Mapa seguido de } \\
\text { texto }\end{array}$ & \\
\hline & $\begin{array}{l}\text { Ícone e nome da } \\
\text { seção Texto e ação }\end{array}$ & $\begin{array}{l}\text { Sete questões } \\
\text { relacionadas ao } \\
\text { texto e ao mapa. }\end{array}$ \\
\hline \multirow{8}{*}{2 Globalização } & Texto & dos autores \\
\hline & $\begin{array}{l}\text { Ícone indicando que } \\
\text { há um Objeto } \\
\text { Educacional Digital }\end{array}$ & $\begin{array}{l}\text { Jogo eletrônico } \\
\text { educativo sobre as } \\
\text { características e as } \\
\text { implicações de se } \\
\text { viver em um mundo } \\
\text { globalizado. }\end{array}$ \\
\hline & $\begin{array}{l}\text { Ícone indicando a } \\
\text { seção Glossário }\end{array}$ & $\begin{array}{l}\text { autossuficiente } \mathrm{e} \\
\text { significado }\end{array}$ \\
\hline & \multirow{2}{*}{$\begin{array}{l}\text { Duas fotografias } \\
\text { seguidas de } \\
\text { legendas. }\end{array}$} & $\begin{array}{l}\text { mulher acessando } \\
\text { a internet em um } \\
\text { café, em Pequim, } \\
\text { na China, em } \\
2012 \text {. }\end{array}$ \\
\hline & & $\begin{array}{l}\text { Consumidora } \\
\text { fazendo } \\
\text { pagamento com } \\
\text { cartão de crédito. }\end{array}$ \\
\hline & Texto em boxe & $\begin{array}{l}\text { Turismo } \\
\text { Internacional } \\
\text { registra } \\
\text { crescimento de } \\
6,7 \% \text { em } 2010 .\end{array}$ \\
\hline & $\begin{array}{l}\text { Ícone e nome da } \\
\text { seção Geolink } 1\end{array}$ & A globalização \\
\hline & $\begin{array}{l}\text { Questões } \\
\text { relacionadas }\end{array}$ & três questões \\
\hline
\end{tabular}




\begin{tabular}{|c|c|c|}
\hline & texto & \\
\hline & $\begin{array}{l}\text { Ícone e nome da } \\
\text { seção Texto e ação }\end{array}$ & quatro questões \\
\hline \multirow{5}{*}{ Expansão das Multinacionais } & Texto & dos autores \\
\hline & \multirow{4}{*}{$\begin{array}{lr}\text { Quatro } & \text { fotos } \\
\text { seguidas } & \mathrm{de} \\
\text { legendas } & \end{array}$} & $\begin{array}{l}\text { O Banco do Brasil } \\
\text { tem agências em } \\
\text { vários países. Na } \\
\text { foto, logotipo do } \\
\text { banco na agência } \\
\text { de Lisboa, } \\
\text { Portugal. }\end{array}$ \\
\hline & & $\begin{array}{l}\text { Trabalhador em } \\
\text { uma fábrica de } \\
\text { pneus chineses em } \\
\text { Rugao, China, em } \\
2009 \text {. }\end{array}$ \\
\hline & & $\begin{array}{l}\text { Fábrica de uma } \\
\text { indústria } \\
\text { automobilística } \\
\text { coreana em Ulsan, } \\
\text { Coreia do Sul, em } \\
2011 .\end{array}$ \\
\hline & & $\begin{array}{lr}\text { Fábrica } & \text { de } \\
\text { automóveis } & \\
\text { indianos } & \text { em } \\
\text { Sanand } & \text { Taluka, } \\
\text { Índia, em } 2010 .\end{array}$ \\
\hline \multirow[b]{5}{*}{ Globalização e desigualdades internacionais } & Texto & dos autores \\
\hline & $\begin{array}{l}\text { Ícone indicativo da } \\
\text { seção Glossário }\end{array}$ & $\begin{array}{l}\text { Mercado } \\
\text { Consumidor } \\
\text { Potencial seguido } \\
\text { de significado. }\end{array}$ \\
\hline & Texto em box & dos autores \\
\hline & $\begin{array}{l}\text { Ícone e nome da } \\
\text { seção Texto e ação }\end{array}$ & Quatro questões \\
\hline & $\begin{array}{l}\text { Ícone e nome da } \\
\text { seção Geolink } 2\end{array}$ & $\begin{array}{l}\text { Globalização } \\
\text { aumenta } \\
\text { desigualdade, diz }\end{array}$ \\
\hline
\end{tabular}




\begin{tabular}{|c|c|c|c|}
\hline & & & ONU \\
\hline & & $\begin{array}{l}\text { Questões } \\
\text { relacionadas a } \\
\text { Geolink 2 }\end{array}$ & Quatro questões. \\
\hline \multirow{27}{*}{ Para fechar o capítulo } & \multirow{9}{*}{ + Ação } & texto & retirado de site \\
\hline & & questões & Cinco questões \\
\hline & & Pergunta & \\
\hline & & Texto & retirado de site \\
\hline & & Questões & duas questões \\
\hline & & $\begin{array}{l}\text { Comando } \quad \text { da } \\
\text { questão } 3\end{array}$ & \\
\hline & & Mapa & $\begin{array}{l}\text { Turismo } \\
\text { Internacional }\end{array}$ \\
\hline & & Questões & Três questões \\
\hline & & Questão quatro & reflexões \\
\hline & \multirow{12}{*}{$\begin{array}{l}\text { De olho na } \\
\text { imagem }\end{array}$} & Comando & \\
\hline & & Figura & $\begin{array}{l}\text { Imagem de um } \\
\text { Jornal antigo }\end{array}$ \\
\hline & & Texto em box & retirado de site \\
\hline & & Questões & Três questões \\
\hline & & Comando & \\
\hline & & Figura & Charge \\
\hline & & Texto em box & \\
\hline & & Questões & Duas questões \\
\hline & & Comando & \\
\hline & & Figura & Charge \\
\hline & & Texto em box & retirado de site \\
\hline & & Questões & Duas questões \\
\hline & \multirow{6}{*}{ Conexões } & Comando & \\
\hline & & Tabela & $\begin{array}{l}\text { Exportações } \\
\text { mundiais de café a } \\
\text { todos os destinos - } \\
12 \text { meses (sacas de } \\
60 \mathrm{Kg} \text { ) }\end{array}$ \\
\hline & & Texto & retirado de site \\
\hline & & Questões & Duas questões \\
\hline & & Comando & \\
\hline & & Letra de Música & Disneylândia \\
\hline
\end{tabular}




\begin{tabular}{|l|l|l|l|l|}
\hline & & & Questões & Quatro questões \\
\hline
\end{tabular}

Fonte: elaborado pela autora com base nas informações do livro Projeto Teláris - Geografia $-9^{\circ}$ ano

No livro Expedições Geográficas, o tema Globalização é apresentado no capítulo 6, o qual é chamado de Percurso 6. O nome do capítulo é População Mundial: cidades e consumo, e o conteúdo é distribuído ao longo de seis páginas. O Percurso 6 é constituído pelo texto produzido pelos autores, três mapas, três seções laterais - trazem sugestões de leituras, filmes etc. -, uma ocorrência de glossário e as atividades dos percursos 5 e 6 constituídas de 7 atividades, as quais devem ser precedidas de reflexões; retomadas de informações dos textos; observação de mapa e de gráfico, bem como da leitura de fragmentos de textos.

\section{Quadro 6: Resumo da Constituição do Capítulo Analisado - Expedições Geográficas ${ }^{15}$}

\begin{tabular}{|c|c|c|c|c|}
\hline \multirow{7}{*}{ 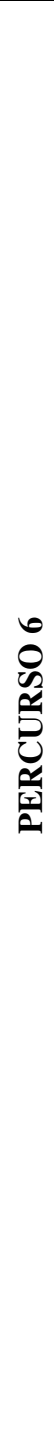 } & \multirow{7}{*}{$\begin{array}{l}\text { População mundial: cidades e } \\
\text { consumo }\end{array}$} & \multirow{4}{*}{$\begin{array}{l}\text { O crescimento } \\
\text { da população } \\
\text { urbana e as } \\
\text { megacidades }\end{array}$} & $\begin{array}{l}\text { Ícone e nome da } \\
\text { Seção } \\
\text { Navegar é preciso }\end{array}$ & $\begin{array}{l}\text { Referência a uma } \\
\text { página de um jornal } \\
\text { que apresenta } \\
\text { diversas } \\
\text { informações sobre } \\
\text { megacidades. }\end{array}$ \\
\hline & & & Texto & dos autores \\
\hline & & & Figura & $\begin{array}{lr}\text { mapa } & \mathbf{A} \\
\text { população } & \text { das } \\
\text { megacidades } & \end{array}$ \\
\hline & & & Um questionamento & $\begin{array}{l}\text { Qual será a maior } \\
\text { cidade do } \\
\text { continente } \\
\text { americano em } \\
2025, \quad \text { segundo } \\
\text { estimativa das } \\
\text { Nações Unidas? }\end{array}$ \\
\hline & & \multirow{2}{*}{$\begin{array}{l}2 \quad \text { Cidades e } \\
\text { hábitos de } \\
\text { consumo } \\
\text { mundializados }\end{array}$} & Texto & dos autores \\
\hline & & & $\begin{array}{l}\text { Ícone e nome da } \\
\text { seção Quem lê } \\
\text { viaja mais }\end{array}$ & $\begin{array}{lr}\text { Indicação de livro } \\
\text { sobre } & \\
\text { globalização. } & \end{array}$ \\
\hline & & & Ícone e nome da & Indicação \\
\hline
\end{tabular}

\footnotetext{
${ }^{15}$ Descrição com base nas informações contidas nas páginas60-65 do livro de Geografia para o $9^{\circ}$ do ensino fundamental, Expedições Geográficas.
} 


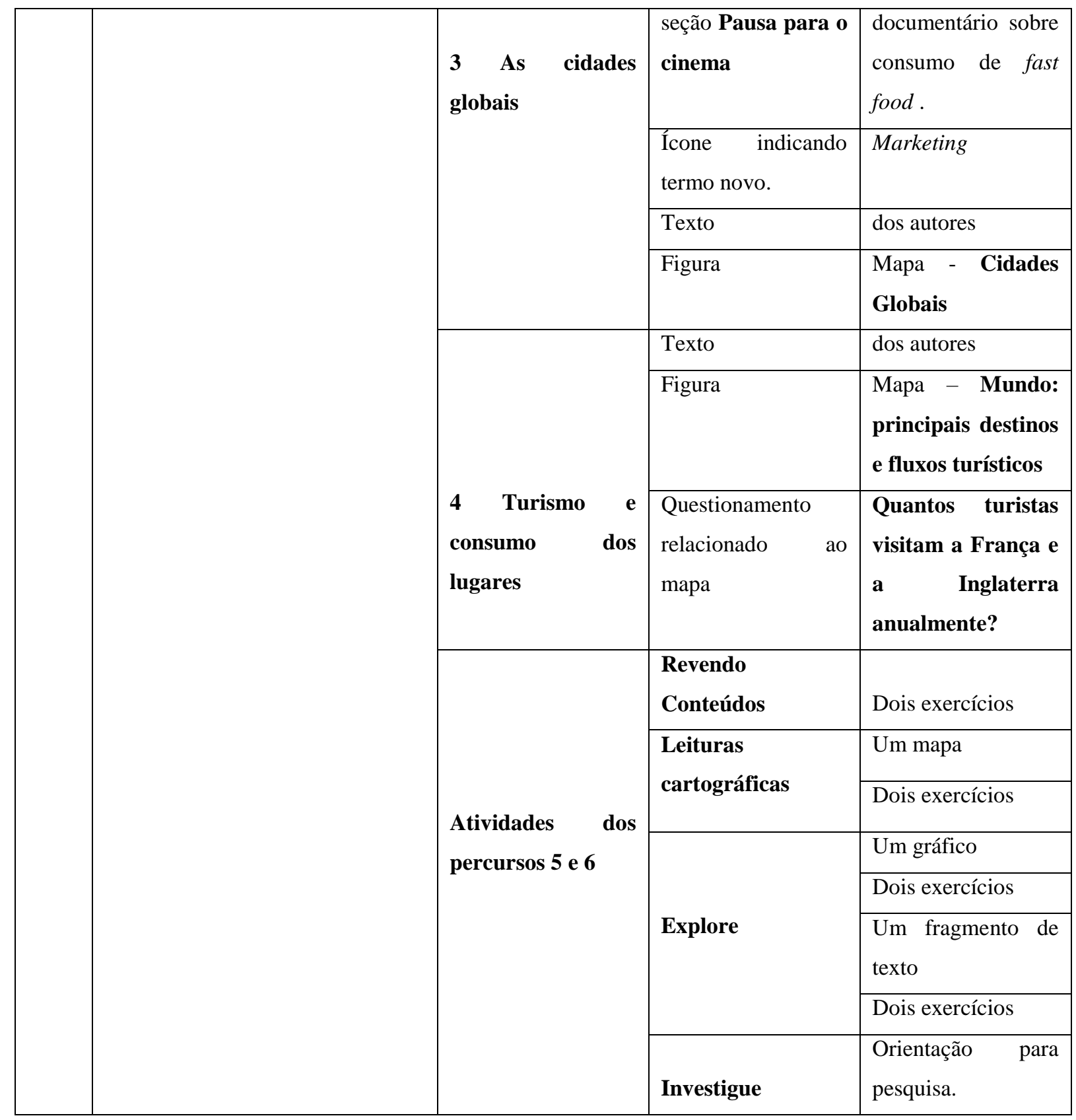

Fonte: elaborado com base nas informações do livro Expedições Geográficas - $9^{\circ}$ ano

O livro de Geografia mais adotado no PNLD 2014, Projeto Araribá, aborda a Globalização no primeiro capítulo da unidade 2, nomeada de Globalização e organizações mundiais. Os capítulos nesse livro são chamados de temas, e o Tema 1 da Unidade 2 recebe o nome de A globalização e seus efeitos e é desenvolvido ao longo de quatro páginas. $\mathrm{O}$ capítulo é constituído de quatro colunas laterais, dispostas ao lado do texto produzido pelos autores, de um quadro e de seis figuras. 
Quadro 7: Resumo da Constituição do Capítulo Analisado - Projeto Araribá ${ }^{16}$

\begin{tabular}{|c|c|c|c|}
\hline \multirow{17}{*}{ A globalização e seus efeitos } & Coluna lateral & $\begin{array}{l}\text { Resumo do assunto } \\
\text { tratado no capítulo }\end{array}$ & \\
\hline & Seção Glossário & Três palavras & $\begin{array}{l}\text { Transnacional } \\
\text { Biotecnologia } \\
\text { Robótica }\end{array}$ \\
\hline & \multirow[t]{4}{*}{$\begin{array}{l}\text { O que significa, } \\
\text { afinal, } \\
\text { globalização? }\end{array}$} & $\begin{array}{l}\text { Questionamento } \\
\text { retórico, pois a } \\
\text { resposta } \\
\begin{array}{ll}\text { apresentada é } \\
\text { seguida. }\end{array}\end{array}$ & \\
\hline & & Texto & dos autores \\
\hline & & Citação & \\
\hline & & Texto & dos autores \\
\hline & \multirow{4}{*}{$\begin{array}{l}\text { As fases da } \\
\text { Globalização }\end{array}$} & Texto & \\
\hline & & Texto & \\
\hline & & Quadro & $\begin{array}{l}\text { Ooder das } \\
\text { transnacionais } \\
\text { globais }\end{array}$ \\
\hline & & Figura & Fotografia \\
\hline & \multirow{4}{*}{$\begin{array}{l}\text { Globalização } \\
\text { Desemprego }\end{array}$} & Seção Glossário & Três expressões. \\
\hline & & Seção Para Ler & $\begin{array}{l}\text { Indicação de livro } \\
\text { sobre a globalização. }\end{array}$ \\
\hline & & Figura & Fotografia \\
\hline & & Texto & \\
\hline & \multirow{3}{*}{$\begin{array}{l}\text { Globalização, } \\
\text { cultura } \\
\text { sociedade } \\
\text { consumo }\end{array}$} & texto & \\
\hline & & texto & \\
\hline & & Figuras & Quatro fotografias. \\
\hline
\end{tabular}

Fonte: elaborado pela autora com base em informações do livro Projeto Araribá

Nesse livro não foram apresentados os exercícios, pois eles estão presentes ao final do Tema 2 da Unidade 2.

No apêndice I, encontra-se um quadro comparativo entre as características dos três livros analisados.

\footnotetext{
${ }^{16}$ Descrição com base nas informações contidas nas páginas 38-41 do livro de Geografia para o $9^{\circ}$ do ensino fundamental, Projeto Araribá.
} 
As descrições acima oferecem uma noção geral sobre os capítulos analisados, contudo, para a identificação dos gêneros textuais e para a compreensão de como a globalização é representada nos livros didáticos, utilizei as categorias de descrição da GSF. E, apesar de buscar nas orações as respostas para a representação do tema, levei em consideração o fato que as orações são multifuncionais, então não as descrevi apenas com base no Sistema da Transitividade, mas também, com base no Sistema de MODO e Modalidade e da Estrutura Temática, objetivando encontrar padrões linguísticos que auxiliassem as análises para determinação dos gêneros.

Em relação ao sistema da transitividade, primeiramente, separei os textos verbais das outras semioses; depois, dividi os textos e orações; em seguida, localizei os processos e os classifiquei; após essa etapa, classifiquei os outros participantes. E, finalmente, tentei encontrar elementos que eram mais frequentes.

Aproveitando as descrições do Sistema da Transitividade, logo abaixo, identifiquei os sujeitos das orações e os finitos, definindo tempo verbal, polaridade e modalidade. Assim, descrevi os elementos mais importantes do Sistema de MODO e Modalidade, aqueles que se encontram no Modo.

Para a descrição da Estrutura Temática, identifiquei em cada oração tudo o que estava na posição inicial até o primeiro elemento constituinte da metafunção experiencial, isto é, processo, participante ou circunstância; e separei temas de remas. Após essa divisão, conforme procedi nas outras descrições, procurei encontrar padrões, elementos articuladores entre as ideias, que pudessem indicar relações de causa, consequência, explicação.

Os outros modos semióticos foram descritos e analisados com base nas categorias da Gramática do Design Visual. Características foram observadas, visando com isso, identificar todos os detalhes de realce por cor, por proporção. Logo após, com base nas investigações de Unsworth e outros pesquisadores, busquei identificar como os diversos elementos constituintes dos capítulos - textos, fotografias, mapas, legendas, seções laterais, ícones estavam relacionados. 


\section{CAPÍTULO 3 - ANÁLISES}

\subsection{INTRODUÇÃO}

Neste capítulo serão apresentadas as análises e discussões sobre os textos investigados. Tais análises têm como base a Gramática Sistêmico Funcional, a Teoria Semiótica Social da Multimodalidade e a Teoria de Gêneros da Escola de Sydney. Na seção 3.2 são apresentados os significados ideacionais encontrados nos livros. (apêndices II, III e IV). Na seção 3.3, os significados interpessoais são apresentados. (apêndices II, III e IV). Logo após, na seção 3.4, as características linguísticas dos textos verbais, que contribuem para articular as informações, são apresentadas (apêndices II, III, IV, V, VI e VII), seguidas das análises dos outros modos e dos significados construídos com base nas relações entre os modos. Por último, na seção 3.5, as características linguísticas que contribuem para a definição dos gêneros textuais presentes nos capítulos estudados são apontadas.

\subsection{CAMPO}

Em relação à variável campo, que diz respeito às atividades sociais e é representada linguisticamente pelo sistema da transitividade, pode-se afirmar que o Tema $\mathbf{1}-\mathbf{A}$ globalização e seus efeitos - da unidade 2 do livro Projeto Araribá; o Percurso 6 População mundial: cidades e consumo - da unidade 2 do livro Expedições Geográficas; e o capítulo 12 - Da Divisão Internacional do Trabalho à globalização - da unidade 4 do livro Projeto Teláris tratam do tema globalização e estão presentes em livros didáticos de Geografia destinados a alunos de $9^{\circ}$ ano do Ensino Fundamental. Esses livros foram escritos por graduados e pós-graduados em Geografia, especialistas da disciplina. Também passaram pelo mesmo processo de seleção, o PNLD 2014, logo foram produzidos dentro dos mesmos contextos de cultura e de situação. Então, com base nessas informações comuns, poder-se-ia inferir que os três capítulos são muitos semelhantes. Contudo, com base na Gramática Sistêmico Funcional, as descrições foram feitas e as características linguísticas para determinar semelhanças e diferenças foram identificadas e são apresentadas a seguir.

\subsubsection{Orações}

Os textos foram divididos em orações. No capítulo analisado do livro Projeto Araribá (de agora em diante, livro 1) foram encontradas 53 orações, sendo que 49 são declarativas; 2 , interrogativas; e 2, imperativas. No livro Expedições Geográficas (de agora em diante, livro 2), foram encontradas 46 orações, das quais uma é imperativa e 45 são declarativas. E, no livro Projeto Teláris (de agora em diante, livro 3), foram encontradas 128 orações, das quais 
uma é interrogativa, duas são imperativas e 125 são declarativas. Essa predominância de orações declarativas é condizente com o texto cujo propósito é informar.

Ex.:

Logicamente, os primeiros compram (importam) as matérias-primas dos segundos e estes, por sua vez, compram os produtos industrializados daqueles países do primeiro grupo.

Conforme se verifica no exemplo a seguir, todas as ocorrências de orações interrogativas são perguntas retóricas, isto é, questionamentos que são apresentados, entretanto, imediatamente a resposta é apresentada.

Ex.:

Como ficaram as desigualdades internacionais com a globalização?

E todas as ocorrências de orações imperativas são comandos dados aos leitores (alunos) para que executem o que foi solicitado e, talvez, seguindo essas orientações o aluno consiga compreender melhor os conteúdos.

Ex.:

Observe as figuras 3 a 6: elas representam algumas contradições da globalização e da sociedade de consumo.

De acordo com Martin e Rose (2007), as relações lexicais auxiliam na construção do campo, e ao observar essas relações em cada um dos textos analisados pode-se afirmar qual o caminho escolhido pelos autores.

No livro Projeto Araribá, foram encontrados diversos elementos relativos ao campo

a) da informação,

Ex.

A partir dos anos 1970, teve início a revolução técnico-científico-informacional, baseada na indústria de microeletrônica, na informática e na tecnologia da informação.

b) da tecnologia

Ex.

A biotecnologia e a robótica são também setores importantes nessa fase do capitalismo

O processo de desenvolvimento das forças produtivas vem empregando tecnologias de produção cada vez mais avançadas.

c) da produção

ex. 
[...] produzem-se cada vez mais mercadorias em tempos cada vez menores.

Esse fenômeno é chamado de aumento de produtividade.

Para ele, a expansão da produção industrial, somada ao crescimento da produção cultural e da propaganda, estaria vinculada à criação de uma "indústria cultural[...]

Logo, percebe-se que a escolha feita pelos autores foi em direção a uma perspectiva em que o acesso às novas tecnologias e às informações permitiram os avanços na produtividade.

No livro Expedições Geográficas, como o título do capítulo é População Mundial: cidades e consumo, as relações lexicais mais marcantes são as relacionadas à população urbana e os problemas relacionados a ela, conforme se observa nos exemplos.

Ex.

Até o início do século XIX, a população mundial residente nas cidades nunca excedeu $7 \%$ da população total.

Assim, uma parcela cada vez maior da população mundial estará exposta à pobreza, ao desemprego e aos riscos ambientais associados à urbanização acelerada, como a deficiência de saneamento básico.

Segundo a ONU, cerca de $\mathbf{3 0 \%}$ da população urbana mundial é pobre, [...]

Também foram utilizados diversos sinônimos como chamadas cidades globais, megacidades, a rede de cidades globais, cada cidade global, para manter as relações lexicais.

No livro Projeto Teláris, foram encontrados diversos sinônimos - Globalização, interdependência, processo de união, essa integração -; contrastes - países desenvolvidos/países subdesenvolvidos, importam/exportam, matérias-primas/ produtos industrializados ou bens industrializados, isoladas/ integradas -; além de reiteradas repetições dos termos globalização e Divisão Internacional do Trabalho (DIT) E essas relações lexicais indicam que o caminho escolhido pelos autores do texto foi o de focalizar os significados da globalização e da DIT relacionados às mudanças nas relações entre os países.

\subsubsection{Processos}

Para o reconhecimento dos significados construídos acerca do campo, foram utilizadas as categorias de descrição e análise da metafunção ideacional ou experiencial, cujo propósito, segundo Halliday (2004), é representar os acontecimentos no mundo físico e os participantes envolvidos no desenrolar desses acontecimentos; ou ainda, representar o mundo da consciência. E os processos representam esses acontecimentos. 
Os processos mais encontrados nos três capítulos descritos foram os materiais, ou seja, aqueles que informam os eventos que ocorreram, ocorrem ou ocorrerão no mundo físico, e para isso foi, é ou será investido algum tipo de energia. Tal predominância justifica-se pelo fato de o propósito dos textos ser a apresentação de informações acerca dos eventos que deram origem à globalização e a eventos que a sucederam, como se verifica nos exemplos a seguir.

Ex.

a) Com isso, ele passou a exportar para os outros países da Europa e dos demais continentes produtos industrializados [...]

b) Tudo muda mais rapidamente hoje.

c) Segundo previsões da ONU, esse número chegará a 4,9 bilhões em 2030,[...]

Como o campo da globalização envolve principalmente relações comerciais e desenvolvimento tecnológico, processos materiais que constroem significados relacionados a essas atividades foram encontrados nos três textos, conforme se observa:

Ex.

os primeiros compram [importam] as matérias-primas dos segundos[...]

[...] e o país vendia aos demais países matérias-primas como arroz[...]

Assim, as empresas transnacionais têm expandido seus negócios

Celulares e microcomputadores, [...] revolucionaram o modo como as pessoas se relacionam com o mundo.

O segundo tipo de processo mais encontrado foi o relacional, responsável por conectar atributo ao portador

Ex.

Segundo a ONU, cerca de $30 \%$ da população urbana mundial é pobre, [...]

e identificador ao identificado.

Ex.

Nas próximas décadas, os países emergentes serão os maiores geradores de megacidades, [...] 
O processo ser, que se trata de um processo relacional, apresentado nos tempos pretérito, presente e futuro, ocorreu com maior frequência, estabelecendo conexões, ora entre identificador e identificado - quando há atribuição de identidade a um participante -; ora entre portador e atributo - quando há atribuição de característica a um participante.

Ex.

a) Essa foi a origem da Divisão Internacional do Trabalho,[...]

b) [...] o processo de união e interdependência entre todos os povos do planeta não é novo.

c) Os problemas associados à urbanização serão mais graves nas megacidades $e$ nas megalópoles

d) O resultado foi a expansão do desemprego nos níveis nacional e global e o aumento do trabalho informal (figura 2).

Os processos relacionais, de acordo com Wignell, Martin e Eggins (1993) são relevantes para a organização dos textos explicativos, pois, antes das sequências de causas e efeitos, são apresentadas definições. E a forma mais provável de elaborar uma definição é por meio de orações relacionais.

Em relação aos processos mentais, comportamentais, existenciais e verbais, pode-se afirmar que houve poucas ocorrências de todos eles, o que se justifica pelo tipo de texto, cujo objetivo não é expor o mundo da consciência, nem discorrer sobre comportamentos específicos. Também não há espaço para diálogos, logo os processos verbais são pouco frequentes. E, em um texto cujo propósito é ensinar, como no caso dos textos investigados, há necessidade não só de definir o fenômeno, mas também de esclarecer sobre o seu surgimento, assim, os processos existenciais não são muito presentes.

\subsubsection{Participantes}

Nos textos descritos, os participantes são bem diversificados, variando entre globalização e os elementos relacionados a ela. Porém, o texto do livro 3 apresenta com maior frequência o participante Divisão Internacional do Trabalho, conforme se verifica nos exemplos que se seguem.

Ex. 
a) Divisão Internacional do Trabalho é o nome que se dá para o comércio mundial no qual cada país está voltado para produzir e exportar determinados bens ou serviços[...]

b) Tradicionalmente, a Divisão Internacional do Trabalho é marcada pela existência de dois principais grupos de países:[...]

c) Foi com a Primeira Revolução Industrial que se estabeleceu essa Divisão Internacional do Trabalho.

d) Essa foi a origem da Divisão Internacional do Trabalho,[...]

e) Assim, a Divisão Internacional do Trabalho foi o resultado da formação de um mercado mundial, [...]

f) Mas foi com a Revolução Industrial, iniciada em meados do século XVIII, que essa Divisão Internacional do Trabalho consolidou,

g) Com essas novas nações independentes, a Divisão Internacional do Trabalho se generalizou [...]

h) A Divisão Internacional do Trabalho manteve e até mesmo agravou as desigualdades internacionais.

i) Um indicador do aumento nas desigualdades entre as nações com a globalização é a nova Divisão Internacional do Trabalho,

Observando os exemplos, pode-se verificar que, apesar de o termo Divisão Internacional do Trabalho ser utilizado diversas vezes ao longo do texto, ora é utilizado como participante de processo material, quando é apresentado como responsável por alguma ação no mundo físico; ora é utilizado como participante de processo relacional, como portador de alguma característica ou como identificador, quando é caracterizado ou identificado.

Em relação a esse recurso - repetição -, Martin e Rose (2007, p.81) afirmam que a repetição e sinonímia são recursos úteis quando o campo de um texto é complexo, pois mantêm uma sequência lexical simples, enquanto relações lexicais complexas vão sendo construídas em torno delas.

Outro aspecto relevante sobre os participantes que constituem os textos é que nenhum deles é um participante específico, isto é, os participantes são grupos representados por povos ou países, ou seja, participantes genéricos. De acordo com Martin e Rose (2008), essa é uma característica encontrada em relatos históricos e em explicações. Os participantes específicos são mais utilizados, dentro dos gêneros das Histórias, em biografias e autobiografias.

Ex. 
a) Isso quer dizer que as economias nacionais estão se desnacionalizando em ritmo acelerado, pois os norte-americanos possuem ações ou títulos de propriedade no Japão, na Europa e na América Latina; os japoneses investem em empresas norte-americanas ou coreanas; os alemães compram ações de empresas russas ou tailandesas; os chineses compram ações de empresas norte-americanas $e$ europeias, etc.

b) [...] ] Reino Unido conquistou o monopólio do desenvolvimento tecnológico.

c) Mas, em 2010, depois de apenas quarenta anos, a China atingiu um total de comércio exterior que ultrapassa os 2 trilhões de dólares,[...]

\subsubsection{Circunstâncias}

A globalização, cujos significados são construídos nos capítulos investigados, apesar de ter recebido esse nome há menos de quatro décadas, já existe há séculos, passou por várias fases e está relacionada a acontecimentos econômicos, sociais e culturais por todo o mundo. Logo, nesses textos há várias ocorrências de circunstâncias, que acrescentam outros significados a esses eventos. E nos livros 1, 2 e 3, as circunstâncias mais presentes são as que indicam tempo, que, segundo Martin e Rose (2008, p.148), na sequência de uma explicação, as relações lógicas entre os eventos são temporais.

Ex.:

a) Quando ela iniciou, em meados do século XVIII, apenas o Reino Unido (Inglaterra) produzia em suas fábricas bens industrializados em grandes quantidades.

\subsubsection{Nominalizações}

A princípio, nesta pesquisa, para identificação de como os eventos foram representados, seriam descritos os processos, os participantes e as circunstâncias. Porém, no início das descrições, uma ocorrência linguística tornou-se frequente nos três livros: as nominalizações, como se observa nos exemplos seguintes

Ex.

Em outras palavras, a Grã-Bretanha se especializou na produção industrial e[...]

Também a existência de carvão mineral, principal fonte de energia no período, possibilitou que a industrialização se iniciasse no Reino Unido.

A globalização pode ser entendida como o conjunto de transformações recentes na economia do planeta, que causaram uma ampliação dos fluxos de mercadorias, uma integração entre os países.

Até o início do século XIX, a população mundial residente nas cidades nunca excedeu $7 \%$ da população total. 
Assim, uma parcela cada vez maior da população mundial estará exposta à pobreza, ao desemprego e aos riscos ambientais associados à urbanização acelerada, como a deficiência de saneamento básico.

Há inúmeros exemplos de nominalizações nos três textos, que, conforme Halliday, são realizações não congruentes - não esperadas. Em outras palavras, esses significados poderiam ter sido construídos de modo congruente - modo esperado -, por meio da utilização de processos e participantes, o que tornaria as construções gramaticalmente densas, visto que mais palavras seriam necessárias para a construção desses significados. Porém, os autores optaram por construções lexicalmente densas.

Com base em Butt et al (1994), o uso de nominalizações pode ser justificado por três motivos. O primeiro é congelar um evento e torná-lo um sujeito que participa de eventos.

Ex.

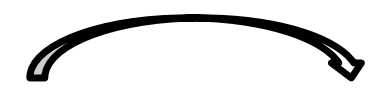

A globalização econômica criou urna grande contradição em seu movimento de modernização das sociedades e criação de um livre comércio mundial:[...]

O segundo motivo deve-se ao fato de que quando um evento é nominalizado, ele torna-se uma entidade que pode ser definida, relatada, descrita, caracterizada, classificada.

Ex.

Divisão Internacional do Trabalho é o nome que se dá para o comércio mundial no qual cada país está voltado para produzir e exportar determinados bens ou serviços. É uma divisão do trabalho entre as economias nacionais.

A globalização consiste numa enorme interdependência entre todos os povos, todas as economias, todos os países do mundo.

E a terceira razão se justifica por conta da variável de registro modo. Pois em textos pertencentes ao contexto familiar, cuja linguagem é mais informal, não há muitas nominalizações. Porém, como os textos investigados são textos informativos, produzidos por especialistas para que estudantes aprendam com as informações e a variedade linguística utilizada é a padrão, há diversas ocorrências desse fenômeno.

\subsection{RELAÇÕES}

Segunda Halliday e Matthiessen (2014), a observação das relações, que são codificadas pela metafunção interpessoal, revela como são construídas as interações entre participantes dentro do texto e entre o autor e o leitor. Dessa forma, pode-se investigar como emissores e receptores interagem, como são feitas propostas (trocas de bens ou serviços) e proposições ( trocas de informações). 
Os constituintes mais significativos da metafunção interpessoal são sujeito e finito. E, nos três textos, poucas orações não são constituídas de sujeito, considerando que há poucas orações existenciais - não possuem sujeito -, e também ocorrem poucas orações na voz passiva sintética. No livro 1, por exemplo, há duas ocorrências de processo existencial e três ocorrências de voz passiva sintética sem sujeito. No livro 2, há duas ocorrências de processo existencial; três de voz passiva sintética e uma de voz passiva analítica, todas sem sujeito. E no livro 3, há oito ocorrências de processo existencial e uma de voz passiva sintética sem sujeito.

Em todos esses casos houve a representação de um evento por meio de um processo, no entanto, não houve a representação de um sujeito, ou porque não existe, ou porque, devido a algum motivo, o sujeito foi omitido, conforme se constata nos exemplos seguintes.

Ex.

a) Atualmente, existem 400 cidades no mundo com mais de um milhão de habitantes.

b) Atualmente, calcula-se que mais de 55 mil empresas podem ser consideradas multinacionais

\subsubsection{Sujeito}

Nos três textos, os sujeitos são bem diversos, pois o tema é amplo e envolve muitos acontecimentos, que ocorreram antes e depois de os estudiosos criarem um termo para rotular os fatores que contribuíram para a globalização e as consequências do seu surgimento. Assim, há muitos participantes e, por conseguinte, uma diversidade de sujeitos.

No livro 1, em relação aos sujeitos que estão relacionados aos eventos, houve a repetição de o capitalismo financeiro - duas ocorrências -; e de vários estados - também duas vezes. No livro 2, ocorrem várias orações com o mesmo sujeito, contudo, isso deve-se ao fato de que em uma oração o sujeito é citado, e na oração seguinte, cujo sujeito é o mesmo, os autores deixaram-no elíptico, como se pode verificar nos exemplos:

Ex.

a) Os modelos de consumo das grandes cidades são difundidos mundialmente

b) e, em geral, [os modelos de consumo das grandes cidades] [são] seguidos por grande parte da população.

c) Assim, as empresas transnacionais têm expandido seus negócios 
d) e [as empresas transnacionais] [têm] investido muito em propaganda, o que influencia na universalização de alguns hábitos e contribui para a promoção da globalização cultural.

E no livro 3, há alguns casos semelhantes ao do livro 2, contudo há também alguns sujeitos como Divisão Internacional do Trabalho e globalização que são repetidos ao longo do texto devido ao fato de serem retomados pelos autores.

Ex.

a) A globalização consiste numa enorme interdependência entre todos os povos, [...]

b) Enfim, a globalização significa que o mundo ficou "menor" ou "encolhido”, [...]

c) A globalização também está associada a uma aceleração do tempo [...]

A repetição, de acordo com Martin e Rose (2007, p.81), é um dos recursos para criar relações taxonômicas entre os elementos do texto, pois esses elementos vão sendo repetidos, retomados por elementos anafóricos ou por sinônimos, formando uma cadeia de relações.

Nos três livros, predominam os sujeitos constituídos por apenas um elemento (substantivo) ou por um grupo nominal, conforme se observa nos exemplos a seguir

Ex.
a) apenas o nome

Em 1950, Nova York era a única megacidade no planeta;

b) o núcleo e outros constituintes

Essas previsões preocupam.

Assim, as empresas transnacionais têm expandido seus negócios

Porém, no livro 1, 5,7\% das ocorrências de sujeitos são de pronomes anafóricos, isto é, pronomes que retomam algum termo anteriormente mencionado. No livro 2, esse fenômeno ocorre em $13,3 \%$ dos casos e no livro 3, em 14,06\%.

Ex.

a) [...] em 1950 elas eram apenas 86 .

b) Isso significa que os produtos com maior tecnologia[...] 
Os pronomes também auxiliam na manutenção das relações lexicais, pois retomam termos anteriormente mencionados.

\subsubsection{Finito}

O finito carrega os significados de tempo, modalidade e polaridade. Na maioria das ocorrências nos três textos investigados, o finito se apresenta no pretérito, o que se justifica pelo fato dos textos apresentarem registros de eventos acerca da globalização que vêm se desenvolvendo há séculos.

Ex.

a) Também a existência de carvão mineral, principal fonte de energia no período, possibilitou que a industrialização se iniciasse no Reino Unido.

b) A África, na verdade, desde o século XVI já participava desse mercado mundial,

Contudo, há ocorrências de finitos no tempo presente, quando acontecimentos atuais são apresentados

Ex.

a) Cerca de 1 bilhão de pessoas moram em áreas irregulares e habitações precárias.

b) A falta de emprego é outro grande problema [...]

E também o tempo futuro é empregado junto às previsões, quase sempre negativas, acerca das condições das populações, especialmente, as das grandes cidades.

Ex.

a) Segundo previsões da ONU, esse número chegará a 4,9 bilhões em 2030,[...]

b) Assim, uma parcela cada vez maior da população mundial estará exposta à pobreza[...]

\subsubsection{Modalidade}

A modalidade textual, de acordo Fuzer e Cabral (2014, p. 114) "é um recurso interpessoal utilizado para expressar significados relacionados ao julgamento do falante em diferentes graus. Refere-se a como falantes e escritores assumem uma posição, expressam uma opinião ou ponto de vista ou fazem um julgamento.” Assim, considerando essa afirmação, pode-se dizer que os autores dos livros ao fazerem as seguintes declarações

Ex.

a) Os estudiosos ainda alertam sobre os diversos danos socioculturais que as atividades turísticas podem causar sobre as comunidades receptoras. 
b) [...] também os chineses, que possuem grande quantidade de ações dessas empresas, ficam preocupados, e o valor dessas ações pode cair drasticamente.

c) [...] a produção agrícola também poderá sofrer grande impacto.

d) A globalização pode ser entendida como o conjunto de transformações recentes na economia do planeta,

foram bastante cautelosos, modalizando as orações com o uso do verbo modal poder, ora para indicar possibilidade de que algo aconteça, ou seja, não há uma certeza, como nos exemplos a, b e c ; ora a possibilidade de que algo possa ser entendido com base em um ponto de vista, como exemplo d, o qual não se trata de uma definição de globalização, mas de um aspecto a ser considerado sobre ela.

\subsubsection{Polaridade}

Conforme Halliday e Matthiessen (2004), a polaridade está nos extremos, de um lado o que é, do outro, o não é. Ou, de um lado o que ocorre, ou o não ocorre. Assim, quando o advérbio não é posicionado ao lado do finito, a polaridade é negativa. Se não é posicionado, a polaridade é positiva.

Observando todas as orações constituintes dos três textos, foi encontrada uma oração com polaridade negativa no texto do livro 1 , duas orações com polaridade negativa no texto do livro 2 e três orações com polaridade negativa no texto do livro 3.

Ex.
同
a) Ex. Como nessas aglomerações não há espaço para a produção de alimentos[...]<smiles>c1ccccc1</smiles>
b) Isso nãa se deve à grande população ou à extensão que possuem,

Isso significa que a maioria das orações, nos três textos, são de representações de fatos que aconteceram, que estão no polo positivo.

Além disso, adjuntos modais podem ser acrescentados às orações a fim de anexar significados de polaridade, modalidade, modo ou temporalidade conforme se verifica nos seguintes exemplos.

Ex.

a) em 2010, apenas trinta anos depois, esse valor já atingia a casa dos 15 trilhões de dólares

b) mas um número imenso de países - especialmente na África, no sul e sudeste da Ásia, na Oceania e na América Latina - ainda continua a exportar 
E há ainda a categoria dos adjuntos de comentário, que, conforme Fuzer e Cabral (2014, p. 118), "expressam o ponto de vista do falante e podem indicar admissão, opinião, desejo, avaliação, predição, presunção, solicitação, dentre outros." Nos textos investigados não houve muitas ocorrências desse recurso, porque o propósito dos textos é informar, mas ainda assim há alguns casos como

Ex.

a) Na verdade, a globalização, junto com a Terceira Revolução Industrial,

b) E o mercado, graças exatamente à ciência e à técnica, torna-se um mercado global.

\subsubsection{Relação autor/ leitor}

De acordo com declaração na seção 1.2.2.2, basicamente a função de interação tem duas finalidades: expressar propostas, quando há troca de bens e serviços; ou expressar proposições, quando há troca de informações Considerando essa afirmação e as análises das orações nos textos, pode-se afirmar que predominantemente os autores, os especialistas, estão dando ao leitor (aluno) as informações acerca do campo que dominam.

Ex.

a) As regiões do globo cujos habitantes possuem melhores condições de vida, como Europa e América do Norte, são as principais áreas receptoras e emissoras de turistas.

b) A indústria cultural busca, por meio da propaganda, estimular o desejo de consumir os chamados "artigos da moda", além de incentivar troca constante dos produtos, tornados rapidamente "obsoletos".

c) Até na cultura vem ocorrendo uma integração mundial - ou globalização da cultura, como dizem alguns -, na medida em que parece que o planeta está ficando menor e que todos se conhecem (assistem a programas semelhantes na televisão, ficam sabendo no mesmo dia o que ocorre no mundo inteiro, etc.).

Contudo, há algumas ocorrências de demanda de informações, que realizadas tipicamente por meio de perguntas. Inclusive, em algumas, os autores utilizam o uso do pronome você, conforme se observa nos exemplos a seguir

Ex.

a) Você já percebeu a quantidade de produtos novos lançados todos os anos? 
No livro 2, ocorrem duas demandas: a primeira, na página 61 , conectada à figura $6-\mathbf{A}$ população das megacidades - 1950-2025

Qual será a maior cidade do continente americano em 2025, segundo estimativa das Nações Unidas?

E a segunda, na página 63, conectada à figura 8 - Mundo: principais destinos e fluxos turísticos.

Quantos Turistas visitam a França e a Inglaterra anualmente?

No livro 3, antes de iniciar o assunto, os autores demandam as seguintes questões:

a) Você sabe que países são os principais exportadores de produtos industrializados?

b) E os exportadores de matérias-primas (gêneros alimentícios e minérios)?

c) O que mudou na Divisão Internacional do Trabalho na nova ordem mundial?

d) Qual o papel desempenhado pelo Brasil na DIT atualmente

Depois, no texto, ainda ocorre solicitação a seguir

Ex.

a) Como ficaram as desigualdades internacionais com a globalização?

Uma terceira estratégia usada pelos autores para realizar a interação com os leitores foi a ordem, realizada linguisticamente por meio de orações no modo imperativo, conformes os exemplos que seguem.

Ex.

a) Observe as figuras 3 a 6 :

b) Observe a figura 7.

c) Para ter uma ideia desse processo de globalização, saiba que em 1960 foram feitos 2 milhões de ligações [...]

d) Basta lembrar que, em 1865, quando o presidente dos Estados Unidos [...]

Um fato relevante, observado apenas no livro 1, é a apresentação, em dois momentos, de vozes de especialistas. Após o início do texto, para referendar a afirmação acerca da importância das inovações tecnológicas, foi utilizada uma citação direta do geógrafo Milton Santos

O geógrafo Milton Santos denomina esse período de técnico-científicoinformacional:

“ [...] Essa união entre técnica e ciência vai dar-se sob a égide do mercado. 
E na seção final, acerca da indústria cultural, a voz do filósofo alemão Theodor Adorno foi usada, por meio de citação indireta, para inquietar o leitor sobre a criação de uma unificação da cultura em todo o mundo, como se constata com o excerto

Em 1940, o filósofo alemão Theodor Adorno contestou a ideia de que, com a abertura comercial e a expansão das comunicações mundiais, haveria a formação de uma "cultura popular" planetária harmoniosa.

Reiterando informação anterior, o texto foi produzido por especialistas no assunto, contudo, a apresentação de vozes de outros especialistas corrobora a ideia apresentada pelos autores do livro.

No livro 2 são utilizados dados de relatórios produzidos pela Organização das Nações Unidas. São apresentadas informações, juntamente com dados numéricos, e, um dos mapas que constituem o capítulo também é da ONU. Porém, nesse caso, os dados não foram utilizados para corroborar as afirmações dos autores, mas para construir boa parte do texto.

\subsection{MODO}

De acordo com Kress (2009, p.54), “modos são recursos socialmente moldados e culturalmente dados para criarem significado. Imagem, escrita, layout, música, gesto, fala, imagem em movimento, trilha sonora são exemplos de modos utilizados na representação e comunicação". Então, nos textos dos livros 1, 2 e 3 são escritos em $3^{\text {a }}$ pessoa, na variedade formal da Língua Portuguesa. Para compor os capítulos, a linguagem verbal é representada com recursos como tipos de fontes diferentes, fontes preto e branco e fontes coloridas, marcação de fontes em itálico e em negrito. E, em relação à linguagem visual, há a presença de mapas, quadros, fotos coloridas, desenhos preto e branco e desenhos coloridos.

No modo escrito, a oração é dividida em duas partes. A primeira parte, o tema, envolve desde o início da oração até o primeiro elemento experiencial - processo, participante ou circunstância - e indica sobre o que é a mensagem. E, logo após está o rema, que se trata do desenvolvimento do tema.

\subsubsection{Modo verbal - Livro 1}

Considerando essas informações e descrição do Tema 1 do livro 1, nas 53 orações, houve a predominância de sujeitos como temas - 28 ocorrências -, fato que evidencia uma tipicidade textual, já que são temas não marcados, ou seja, temas esperados, como se observa nos exemplos

Ex.

a) O geógrafo Milton Santos denomina esse período de técnico-científicoinformacional: 
b) O capitalismo financeiro passou a ter importância fundamental.

Em relação aos temas marcados, menos típicos, o tipo de tema mais encontrado foi o textual - 10 ocorrências -, que tem a função de articular a ideia nova com uma informação apresentada anteriormente conforme se observa nos exemplos que seguem

Ex.

a) e [as empresas transnacionais] [têm] investido muito em propaganda, [...]

b) Contudo, essas inovações não atingem o planeta igualmente, [...]

Outro tipo de tema marcado que ocorreu em mais de $15 \%$ das orações justifica-se pelo fato de o texto apresentar uma síntese dos principais acontecimentos que contribuíram para a globalização, logo, grupos adverbias, que acrescentam significados circunstanciais, foram utilizados e colocados em evidência em oito orações. E o tipo de circunstância que se destacou foi a temporal.

Esse tipo de circunstância, conforme Martin e Rose (2008), auxilia na construção de relação lógica entre os eventos.

Ex.

a) Nesse período, o capital financeiro buscou a ampliação dos mercados e [...]

b) A partir dos anos 1970, teve início a revolução técnico-científico-informacional, [...]

Processos foram temas em quatro orações, sendo que em duas ocorrências as orações foram invertidas, isto é, foram construídas com verbo, complemento e sujeito. Outro caso justifica-se pelo fato da oração estar na voz passiva sintética e o outro, no imperativo.

\subsubsection{Outros Modos}

No livro 1, além do texto principal, há outros elementos que compõe o capítulo. Considerando que da esquerda para a direita as páginas são divididas em três partes, no primeiro terço das páginas pares (à esquerda do livro), são posicionadas as seções laterais; e nos dois outros terços, o texto principal. Nas páginas ímpares (à direita do livro), as seções laterais são posicionadas no primeiro terço da página (da direita para a esquerda), e nos outros dois terços, o texto principal.

Na primeira página do capítulo, na coluna à esquerda do texto principal há quatro informações: no canto superior esquerdo há a presença do nome e do número do capítulo, intitulado Tema 1. Logo abaixo dessa indicação, encontra-se uma síntese do tema desenvolvido no capítulo, em itálico e emoldurado. E, um pouco mais abaixo se encontra a seção Glossário. 
De acordo com Kress e van Leeuwen (2006), quando se deseja salientar algo, ou melhor, quando se deseja evidenciar alguma informação, pode-se destacá-la variando o tamanho, coordenando cores ou posicionando-a em primeiro plano. Considerando essas informações, o nome do capítulo foi destacado por meio de dois recursos: o tamanho da fonte é maior que o da fonte do texto principal; e a cor da fonte é verde, que se diferencia da cor da fonte do texto principal, que é preta. A síntese destaca-se por estar enquadrada em uma moldura tom de terra, e por estar em itálico sobre um fundo bege, quando o texto principal não se encontra em itálico e o fundo da página é branco. E, a seção Glossário também se apresenta em destaque, por estar enquadrada em uma caixa verde claro, com o nome da seção destacado em um verde mais forte, e as palavras, cujos conceitos são apresentados, estarem marcadas em negrito, conforme a figura 9.

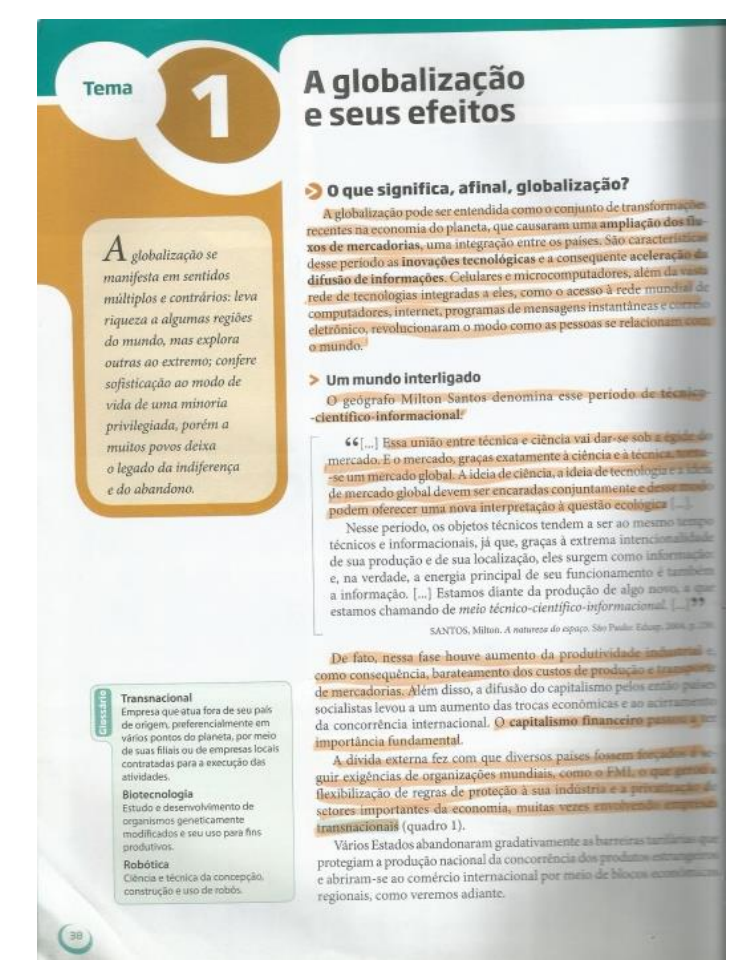

Figura 9: Primeira página do capítulo analisado ${ }^{17}$

Fonte: Livro Projeto Araribá

Há indicação dos títulos e subtítulos das seções por meio de setas indicativas, e esses títulos e subtítulos são destacados por meio do tamanho maior da fonte e por meio da marcação em negrito, que, conforme Lemke,

${ }^{17}$ O capítulo encontra-se todo marcado, provavelmente, pelo ex-dono do livro. Por não conseguir o livro em editoras ou escolas, a pesquisado necessitou adquirir o livro, e o único que conseguiu estava com diversas marcações. 
Tipografia é convencionalmente usada como uma orientação, bem como um recurso organizacional em texto impresso. Em relação à orientação, o uso de fontes em itálico e em negrito sinaliza ênfase ou importância, assim como o tamanho relativo da fonte em títulos, subtítulos, resumos, notas de roda, legenda, rótulos, etc. Organizacionalmente, parágrafos, e seções de textos e relações geométricas entre espaços das figuras e espaços das legendas nos indicam quais elementos devem ser lidos preferencialmente em relação a quais elementos. (LEMKE, 1998, p. 95)

Na segunda página, uma página ímpar, à direita do livro, e, conforme informação anterior, possui uma coluna lateral à direita do texto principal composta por um quadro do Instituto Brasileiro de Geografia e Estatística (IBGE). Esse quadro (Quadro 1) está em destaque, primeiro porque está à direita do texto principal, depois está enquadrado por moldura fina bordô e contém informações textuais, seguidas de uma tabela na cor verde, contendo nomes de países e de empresas transnacionais e o Produto Interno Bruto (PIB) de cada um, com o objetivo de comprovar que algumas dessas empresas possuem o PIB maior que de alguns países.

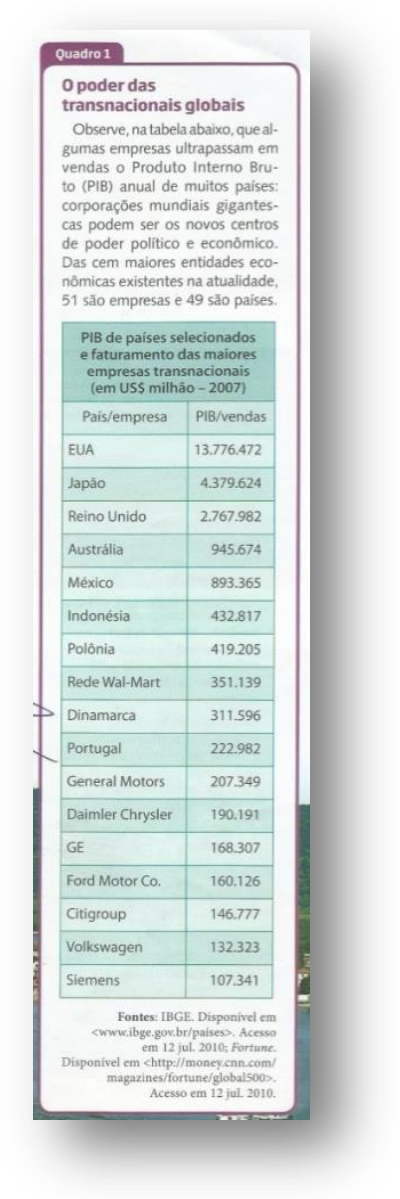

Figura 10: Quadro 1 do livro 1 Fonte: Livro Projeto Araribá 
No terço final dessa página, considerando que a página esteja dividida em três terços, de cima para baixo, há a fotografia de um porto, sobreposta parcialmente pelo Quadro1. Há a presença de uma paisagem natural ao fundo, constituída por morros com vegetação. Em um segundo plano, do fundo para frente, observam-se algumas edificações e pequenas embarcações. E, em destaque, por estar em primeiro plano, no centro da figura, há um navio cargueiro, carregado de containers.

Com base nas categorias de análise da Gramática do Design Visual de Kress e van Leeuwen (2006), a figura é uma foto narrativa, pois é possível verificar a presença de circunstâncias locativa (porto) e temporal (durante o dia), pois como descrito acima, há uma paisagem, céu azul. Também há a presença de diversos participantes representados pelas embarcações maiores ou menores na água. E há a presença de vetor, representado pela linha diagonal na água, indicando o caminho percorrido pelas embarcações. Envolve um processo de ação, por meio da interação entre as embarcações no primeiro plano, quando uma segue a outra, e por meio da corda que conecta a embarcação menor ao cargueiro.

Em relação à interação, como a foto retratou os participantes distantes, o contato e o plano são impessoais. Também, não há envolvimento devido à distância e como a foto foi produzida de um ângulo de cima para baixo, denota poder de quem vê.

E em relação à composição, o mais relevante nesta figura, é acerca do valor da informação, pois aquilo que se quis evidenciar, o cargueiro, está centralizado, e a saliência foi criada, quando se registrou o elemento principal bem maior do que todos os outros elementos.

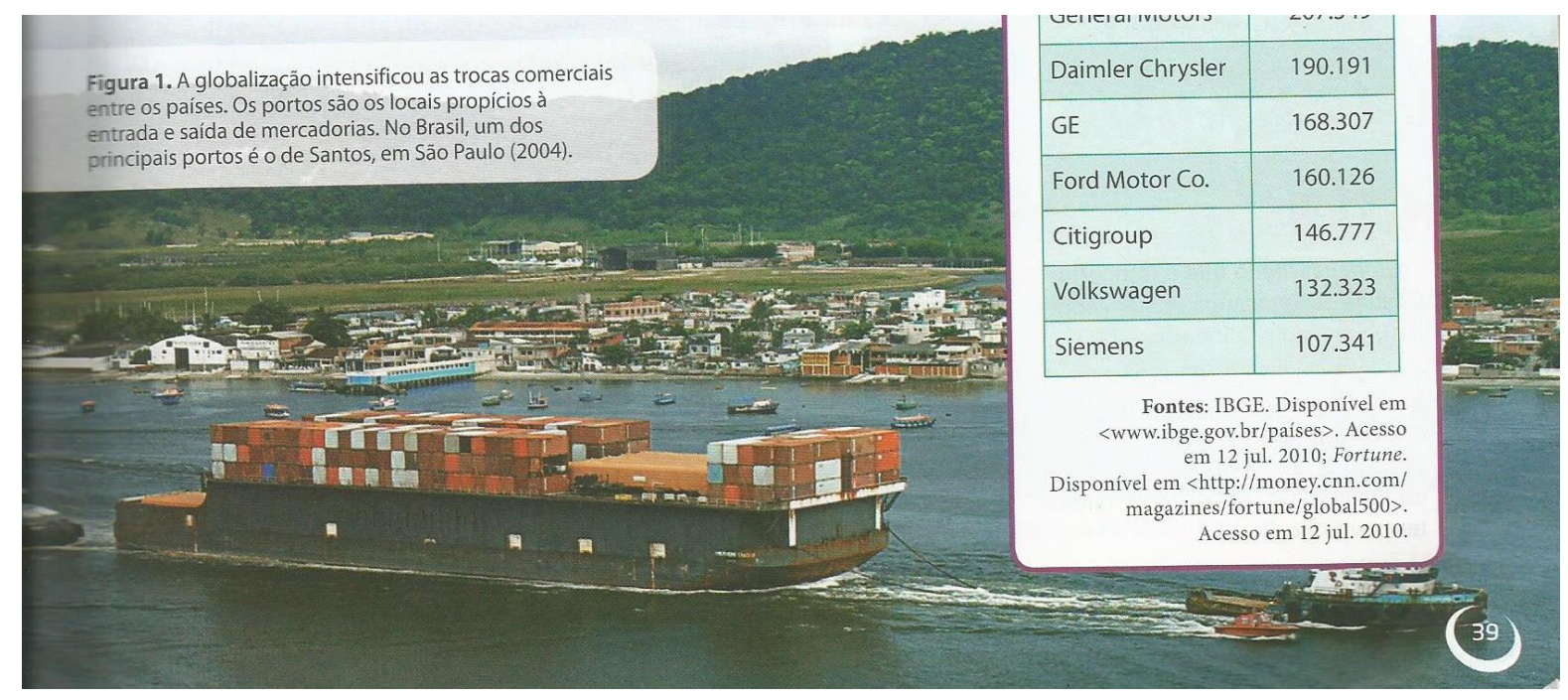

Figura 11: Fotografia 1 do livro 1.

Fonte: livro Expedições Geográficas 
Na legenda há uma oração com processo material, indicando que a globalização tornou possível alguma mudança.

\begin{tabular}{|l|l|l|l|}
\hline A globalização & intensificou & as trocas comerciais & entre os países. \\
\hline ator & processo material & meta & beneficiário \\
\hline
\end{tabular}

E logo após há duas orações identificativas.

\begin{tabular}{|l|l|l|l|}
\hline Os portos & são & os locais propícios & à entrada e saída de veículos \\
\hline \multirow{2}{*}{ identificado } & $\begin{array}{l}\text { processo relacional } \\
\text { identificativo }\end{array}$ & identificador & \\
\hline
\end{tabular}

\begin{tabular}{|l|l|l|l|l|}
\hline No Brasil, & um dos principais portos & é & o de Santos & em São Paulo \\
\hline lugar & identificado & $\begin{array}{l}\text { processo relacional } \\
\text { identificativo }\end{array}$ & identificador & lugar \\
\hline
\end{tabular}

Na figura presente no quadro 8 (página 97), uma foto narrativa, há a presença de diversos participantes posicionados em uma fila, sobre uma calçada. O evento se passou durante o dia e, no segundo plano, percebe-se a presença de pessoas, carros, árvores. O vetor é a fila, que indica que as pessoas estão caminhando. E consiste em uma ação transitiva, pois há conexão entre alguns participantes.

O que se pode perceber acerca da relação entre os participantes é que predomina a impessoalidade entre eles, pois a maioria se encontra de costas uns para os outros, e o poder do fotógrafo em relação às pessoas na fila é evidenciado por meio do ângulo alto. E, no que concerne à relação produtor/ leitor, o produtor ofereceu uma informação de forma impessoal.

Em relação à composição da foto, o enquadramento desperta a atenção, pois o tamanho da fila impressiona pela quantidade de pessoas que está ali pelo mesmo motivo. A saliência fica por conta das pessoas, em sua maioria, vestidas com roupas escuras no meio de uma calçada clara.

A figura 3, presente no quadro 9 (página 98), também é uma figura narrativa. Apresenta três crianças no primeiro plano e os corpos delas são os vetores, pois representam o evento de catar o lixo. O cenário é um lixão que foi registrado durante o dia, e ao fundo, podese observar construções precárias. A foto foi tirada de frente e com uma distância média, o que indica um envolvimento maior com os participantes. Todavia, a imagem foi registrada de um ângulo alto, o que denota o poder do fotógrafo. E, na composição dessa foto, a informação mais importante está enquadrada ao centro dela, e a saliência encontra-se nas roupas coloridas 
das crianças no primeiro plano, em contradição com todo o resto do cenário, que apresenta a mesma cor clara e desbotada.

A figura 4 do quadro 9 (página 98) também é narrativa. Retrata um aterro, durante o dia, porém, ao invés de crianças, ao centro há uma escavadeira, que é o vetor, sendo conduzida por um participante de quem não se pode ver o rosto. No plano de fundo, há o céu azul com muitas nuvens, há uma torre que sustenta fios, pássaros voando. A foto não causa muitas emoções, pois há uma distância social impessoal, estabelecida pelo plano aberto e pela presença do condutor dentro da escavadeira, ou seja, sem envolvimento. Como a máquina está no centro da foto, é a informação mais importante. E, ao consideramos que Kress e van Leeuwen afirmam que na parte de cima da imagem é retratado o ideal e na parte de baixo, o real, poder-se-ia interpretar a foto como se o trator estivesse ali para limpar o aterro, que representa a realidade, e alcançar o ideal, que é o céu azul.

Na figura 5 do quadro 9 (página 99), observa-se no plano de fundo o céu azul uma edificação grandiosa, cercada por árvores, gramado e, aparentemente, um lago. No muro da edificação há uma logomarca e o nome Meliá las Américas. Quase ao centro da foto, há um carrinho para campos de golfe com um condutor dentro. Um pouco mais atrás há outro participante com os tacos de golfe. Tudo compõe uma narrativa com processo de ação transacional, pois possui um vetor, que é o carrinho, e há mais de um participante.

O plano aberto é bastante impessoal, e o distanciamento é corroborado pelo posicionamento dos participantes, que estão de costas. A saliência está nos únicos participantes, no centro da imagem, em meio a paisagem e edificação do hotel.

A figura 6 do quadro 9 (página 99) também é narrativa, com dois participantes deitados de costas, em espreguiçadeiras no primeiro plano. Embaixo da sombra de uma árvore. No meio uma piscina e ao fundo, espreguiçadeiras com pessoas aproveitando o sol ou a sombra das árvores. O distanciamento é alto, pois os participantes estão de costas, e foram registrados tão mimetizados às espreguiçadeiras, que só se percebe a presença de humanos, pelas mãos de um e pelo chapéu de outro. Na composição, verifica-se uma bela paisagem, com bastante verde, o céu azul e a saliência fica por conta da piscina azul e vazia no centro da imagem.

\subsubsection{Relação entre os modos}

De acordo com Unsworth (2006), a GSF e TSSM auxiliam na descrição e análise das semioses verbal e visual, respectivamente. Em outras palavras, essas teorias auxiliam em análises intramodais. Assim, buscando encontrar os significados construídos na intersecção 
dos dois modos, reuniu estudos de diversos pesquisadores que desenvolveram uma metalinguagem para as análises intermodais.

A primeira informação lateral apresentada no livro 1 é uma síntese da globalização como se verifica

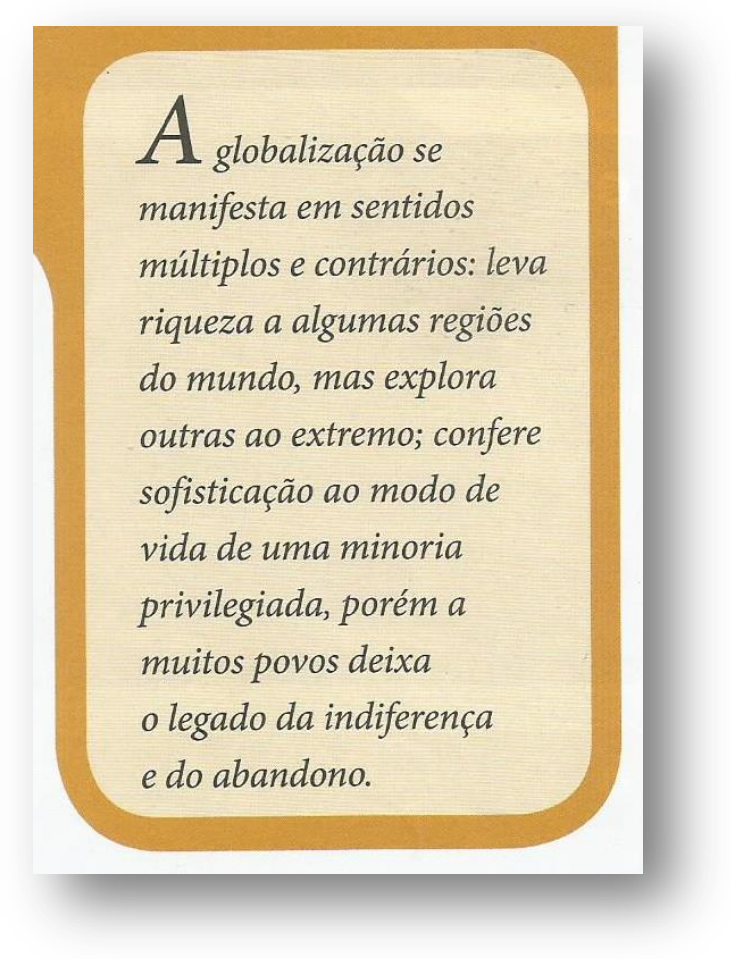

Figura 12: Seção inicial do livro 1

Fonte: Projeto Araribá

E as análises das relações léxico-gramaticais demonstram que a síntese representa a globalização como uma grande contradição, com afirmações seguidas de relações adversativas - mas, porém - e uso de léxico que estabelece contraste - riqueza/ explora, sofisticação/ legado da indiferença e do abandono.

O texto principal é o modo que estabelece os vínculos com os outros modos. Além dos títulos das seções e das subseções, há algumas palavras marcadas em negrito no texto, que, de acordo com Lemke (1998, p. 95), confere-lhes destaque. Algumas delas se encontram assim, porque constituem as ideias-chave, como se pode verificar no exemplo a seguir

Ex.

A globalização pode ser entendida como o conjunto de transformações recentes na economia do planeta, que causaram uma ampliação dos fluxos de mercadorias, uma integração entre os países. São características desse período as inovações tecnológicas e a consequente aceleração da difusão de 
informações. Celulares e microcomputadores, além da vasta rede de tecnologias integradas a eles, como o acesso à rede mundial de computadores, internet, programas de mensagens instantâneas e correio eletrônico, revolucionaram o modo como as pessoas se relacionam com o mundo.

No texto principal há a presença de expressões realçadas com uma faixa verde. Não há nenhuma explicação no texto sobre o porquê desse realce, contudo, essa cor é a mesma da seção Glossário, onde a expressão é explicada. Ou seja, o que conecta os dois textos é a cor, como se observa nas figuras $10^{18}$ e 11 .

\section{A partir dos anos 1970, teve início a revolução técnico-غientítice- -informacional, baseada na indústria de microeletrônica, na informática e na tecnologia da informação. A biotecnologia e a robótica são tamberm setores importantes nessa fase do capitalismo.}

Figura 13 : Fragmento de texto do livro $1 .^{19}$

Fonte: Livro Projeto Araribá

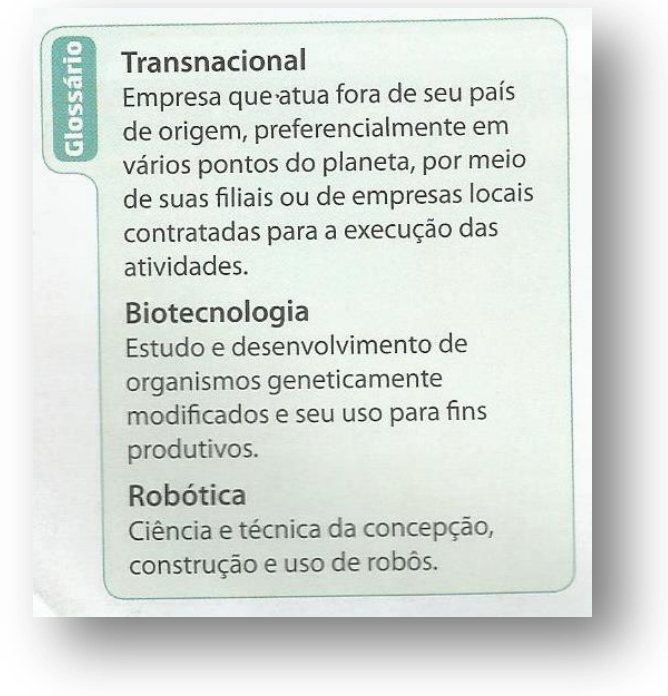

Figura 14 : Seção Glossário do livro 1.

Fonte: Livro Projeto Araribá

A relação entre o texto principal e o quadro 1 é estabelecida por meio da expressão entre parênteses (quadro 1) e essa relação é de complementariedade, pois o quadro apresenta informações que expandem a informação contida no texto principal, sobre as empresas transnacionais,

\footnotetext{
${ }_{18}^{18}$ Marcação feita, provavelmente, pelo ex-dono do livro.

${ }^{19}$ A rasura no fragmento, provavelmente, foi feita pelo ex-dono do livro.
} 
A divida externa fez com que diversos países fossem forçados a seguir exigências de organizações mundiais, como o FMI, o que gerou a flexibilização de regras de proteção à sua indústria e a privatização de setores importantes da economia, muitas vezes envolvendo empresas transnacionais (quadro 1).

Por um lado, entre a figura 11 e a legenda, há uma relação de concordância, que, segundo Unsworth (2006), ocorre quando dois modos semióticos apresentam informações cujos participantes e processos são os mesmos.

Figura 1. A globalização intensificou as trocas comerciais entre os países. Os portos são locais propícios à entrada e saída de mercadorias. No Brasil, um dos principais portos é o de Santos, em São Paulo (2004).

Por outro lado, a relação entre a figura 11 e o texto principal é de complementariedade divergente, pois no texto são apresentadas as seguintes informações junto à indicação da figura 1

O que chamamos de globalização representa, na verdade, a fase atual de um movimento iniciado com as Grandes Navegações, no século XVI, que abriram aos conquistadores europeus as terras do Novo Mundo, principalmente na América (figura 1). Milhares de pessoas migraram para as colônias. Para a exploração econômica das novas terras, utilizou-se a mão de obra escrava vinda da África.

Ou seja, no parágrafo são feitas referências às Grandes Navegações, em outro século, e à colonização, inclusive da América. Logo parece que não há vínculo entre a figura 1 e o texto. Mas, a foto retrata navegações comerciais recentes, logo, há uma complementariedade de ideias que parecem divergentes.

Nas outras páginas, são apresentados os mesmos recursos, como palavras marcadas em negrito, palavras com realce e a seção Glossário. Porém, outra seção lateral é acrescentada. É a seção Para Ler. Nela é apresentada a referência de um livro sobre a globalização. Além de estar destacada do restante do texto por estar posicionada na lateral, encontra-se destacada também por estar enquadrada dentro de uma moldura laranja.

A figura presente no quadro 8 (página 97) possui uma relação de redundância com a legenda, mas possui uma relação de complementariedade com o texto principal, como se observa nas três semioses. 
Quadro 8: Relação entre figura 2, legenda e texto principal

\begin{tabular}{|c|c|c|}
\hline Legenda & Figura 2 & Texto principal \\
\hline $\begin{array}{lr}\text { Fila } & \text { de } \\
\text { desempregados } \\
\text { aguardando para } \\
\text { entrar em } & \text { uma } \\
\text { feira } & \text { de } \\
\text { empregos } & \text { no } \\
\text { bairro } & \text { do } \\
\text { Brooklyn, em } & \text { Novar York } \\
\text { (Estados } & \\
\text { Unidos, 2010). }\end{array}$ & & $\begin{array}{l}\text { A globalização } \\
\text { econômica criou uma } \\
\text { grande contradição em } \\
\text { seu movimento de } \\
\text { modernização das } \\
\text { sociedades e criação de } \\
\text { um livre comércio } \\
\text { mundial: o aumento da } \\
\text { produção de mercadorias } \\
\text { sem o crescimento, na } \\
\text { mesma proporção, do } \\
\text { número de trabalhadores. } \\
\text { O resultado foi a } \\
\text { expansão do desemprego } \\
\text { nos níveis nacional e } \\
\text { global e o aumento do } \\
\text { trabalho informal (figura } \\
\text { 2). }\end{array}$ \\
\hline $\begin{array}{l}\text { A relação entre } \\
\text { a figura } 2 \text { e a } \\
\text { legenda é de } \\
\text { redundância, } \\
\text { pois se pode } \\
\text { identificar na } \\
\text { legenda o que se } \\
\text { percebe na foto. }\end{array}$ & & $\begin{array}{l}\text { A figura tem uma relação } \\
\text { de complementariedade } \\
\text { com o texto, pois ela } \\
\text { acrescenta informações } \\
\text { sobre o desemprego. }\end{array}$ \\
\hline
\end{tabular}

Fonte: elaborado pela autora com base em informações do livro Projeto Araribá

As figuras presentes no quadro 9 (páginas 98 e 99) foram utilizadas para informar sobre as dicotomias provocadas pela globalização, conforme são apresentadas no texto.

Observe as figuras 3 a 6: elas representam algumas contradições da globalização e da sociedade de consumo.

Elas estão na seção Globalização, cultura e sociedade de consumo e estabelecem uma relação de complementariedade com o texto, que, segundo Unsworth (2006), ocorre quando os dois modos não apresentam as mesmas informações, mas elas se complementam, neste caso, expandindo informações como a seguinte 
Vimos que cada fase da globalização é marcada por uma onda de inovações tecnológicas. Contudo, essas inovações não atingem o planeta igualmente, quer por razões econômicas possibilidade de acesso e consumo de novos produtos -, quer por razões culturais.

Quadro 9: Relação entre as figuras 3, 4, 5 e 6 e respectivas legendas.

\begin{tabular}{|c|c|c|}
\hline Número & Figura & Relação com a legenda \\
\hline 3 & $\begin{array}{l}\text { Figura } 3 . \\
\text { Java (Indo }\end{array}$ & Relação de Concordância \\
\hline 4 & Tigura 4. & Relação de Concordância \\
\hline 5 & & Relação de Concordância \\
\hline
\end{tabular}




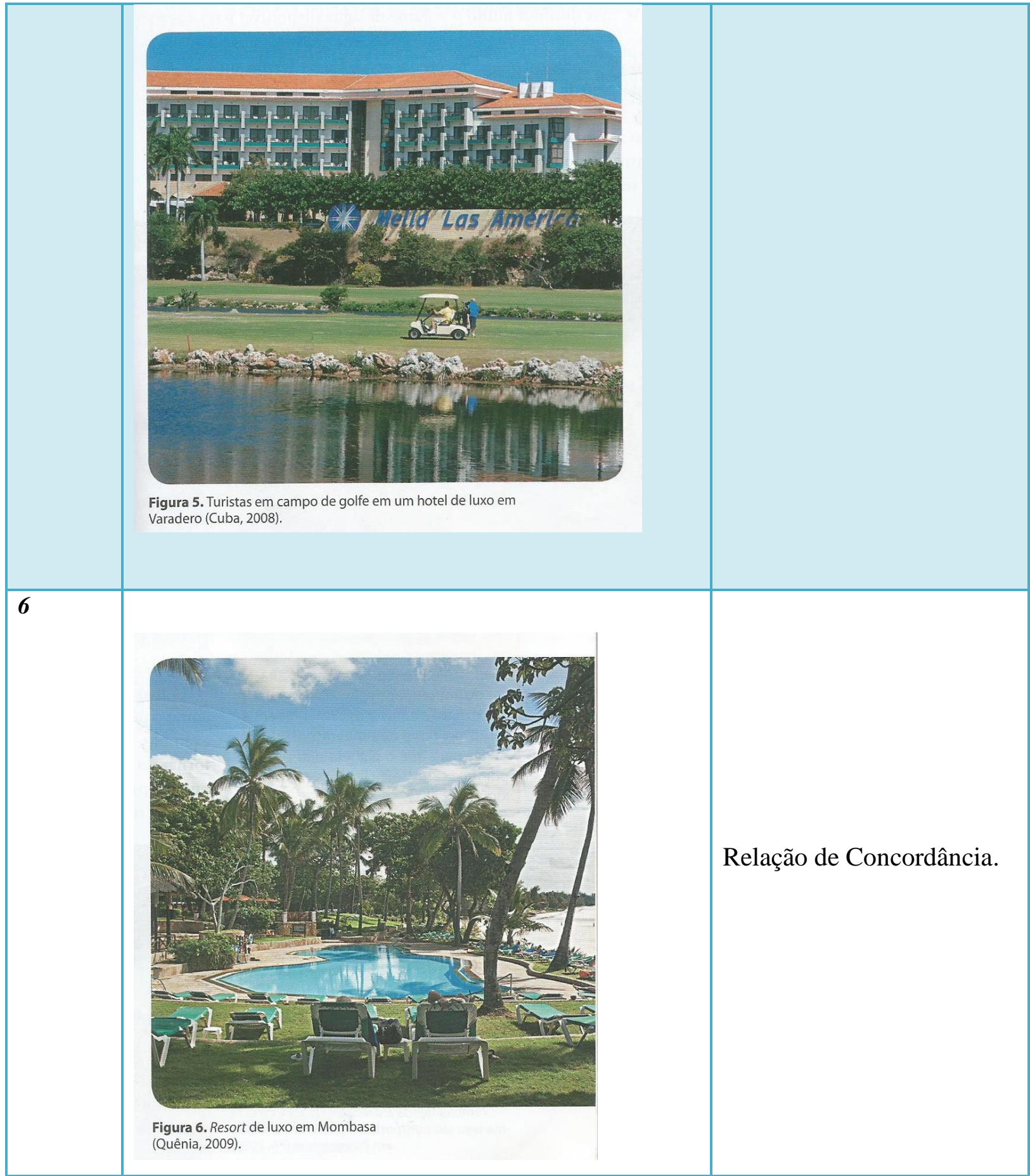

Todas as imagens apresentam relação de concordância com as legendas, pois as informações verbalizadas nas legendas são concordantes com as informações visualizadas, conforme classificação apresentada por Unsworth (2006).

\subsubsection{Modo Verbal - Livro 2}

Nas 46 orações do Percurso 6 do livro 2, 27 possuem temas ideacionais. Contudo, em 14 orações, circunstâncias foram colocadas em evidência, pois no texto principal, os autores 
apresentaram como alguns problemas eram antes da globalização, como estão e como ficarão, conforme se constata nos exemplo a seguir

Ex.

Até o início do século XIX, a população mundial residente nas cidades nunca excedeu $7 \%$ da população total.

Cerca de dois séculos depois, em 2008, pela primeira vez na história constatou-se que a população urbana havia ultrapassado 50\% (cerca de 3,3 bilhões de pessoas).

Em 13 orações, foram encontrados temas não marcados, evidenciando uma tipicidade linguística: um sujeito como informação. E diversos temas são repetidos, ainda que elipticamente, como se verifica nos exemplos seguintes:

Ex.

a) As chamadas cidades globais ou mundiais desenvolveram-se nos últimos 25 anos do século $X X$.

b) São verdadeiras "portas de entrada" para os hábitos de consumo difundidos mundialmente nos países onde estão localizadas

E 13 orações apresentam tema textual, indicando articulação entre as ideias, por meio de conjunções conforme os exemplos apresentados a seguir.

Ex.

a) cerca de 1 bilhão de pessoas moram em áreas irregulares e habitações precárias

b) e entre 20 e 40 milhões de famílias não têm moradia.

\subsubsection{Outros Modos - livro 2}

Assim como o livro 1, o livro 2, além do texto principal, apresenta seções com informações complementares, dispostas nas laterais externas das páginas. Porém, ao contrário do livro, que tem as informações verbais complementadas por fotografias; o livro 2 apresenta outras informações por meio de três mapas.

A primeira informação no canto superior da página 60 - página da esquerda e a primeira do capítulo - há uma figura que representa uma placa de trânsito, amarela, com a inscrição PERCURSO e o número 6 saliente, devido ao tamanho da fonte ser bem maior que todas as outras utilizadas na página.

O título do capítulo e os títulos das seções são salientados pelos tamanhos das fontes, que são bem maiores que o tamanho da fonte utilizado no texto; e se encontram marcados em negrito. Logo abaixo do título, há uma seção sinalizada pelo número 1 na cor branca, realçado por estar dentro de um ícone vinho. 
No texto, as palavras megacidades, megalópoles, alfa, beta e gama e os grupos nominais globalização cultural e cidades globais, ao serem escritos pela primeira vez, foram salientados pelo negrito, o que coincide com Wignell, Martin e Eggins (1993) que afirmam que

a principal função da marcação de termos dessa forma é sinalizar que um significado específico de campo está prestes a ser dado. E um termo marcado deve ser acompanhado por uma definição, ou uma elaboração. Tipicamente, uma vez que o termo foi elaborado, já não é mais realçado. (WIGNELL, MARTIN e EGGINS, 1993, p. 164)

Ao longo do capítulo, há três mapas e quatro seções laterais. Aqueles intitulados como figuras 6, 7 e 8; e estas, cada qual com um ícone alusivo ao assunto, representado por uma placa semelhante à de trânsito; um nome e o conteúdo, encontram-se todas enquadradas e localizadas nas laterais do texto principal, conforme se verifica a seguir.

\section{Quadro 10: Seções complementares do livro Expedições Geográficas.}

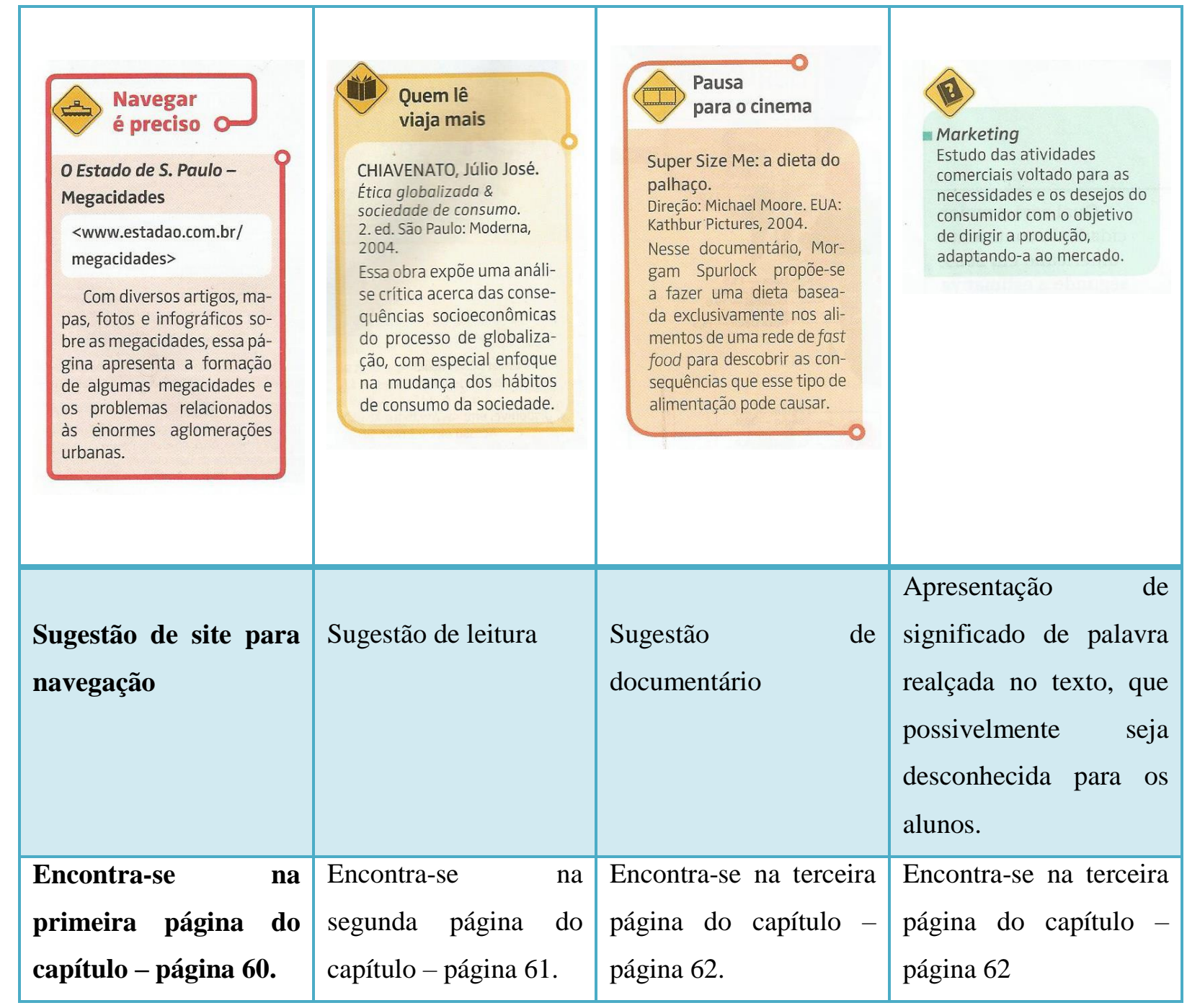

Fonte: livro Expedições Geográficas 
3.4.6 Relações entre os modos - livro 2

As seções Navegar é preciso, Quem lê viaja mais e Pausa para o cinema encontram-se localizadas nas páginas onde estão os temas tratados e, ainda que não haja nenhuma referência no texto sobre essas seções, elas são sugestões de atividades que o aluno pode desenvolver para expandir os conhecimentos sobre o tema, logo, possuem uma relação de complementariedade com o texto principal, como se observa na figura 12.

Ex

\section{(2) Cidades e hábitos de consumo mundializados}

Atualmente, existem 400 cidades no mundo com mais de um miIhão de habitantes; em 1950 elas eram apenas 86. Desde as últimas décadas, o acréscimo de pessoas nas cidades tem impulsionado o aumento do consumo de produtos diversos, desde aqueles essenciais à sobrevivência, como os alimentos, até os produtos mais supérfluos. Como nessas aglomerações não há espaço para a produção de alimentos, as pessoas são obrigadas a adquiri-los em feiras e supermercados, ou em outras fontes de abastecimento. Além disso, o estilo de vida nas grandes cidades demanda o uso de produtos específicos para as pessoas trabalharem, se locomoverem, se comunicarem, entre outros.

Os modelos de consumo das grandes cidades são difundidos mundialmente e, em geral, seguidos por grande parte da população. Assim, as empresas transnacionais têm expandido seus negócios e investido muito em propaganda, o que influencia na universalização de alguns hábitos e contribui para a promoção da globalizacão cultural.

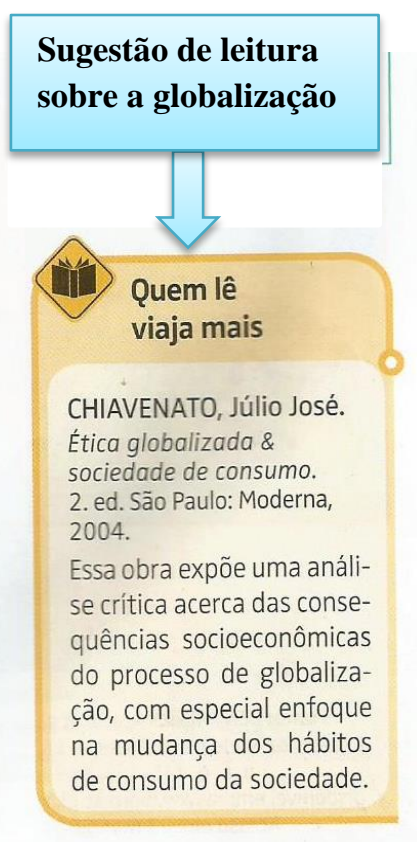

Figura 15: Relação entre texto e seção lateral.

Fonte: livro Expedições Geográficas

$\mathrm{Na}$ página, o texto principal introduz o termo globalização cultural e logo ao lado encontra-se a seção lateral Quem lê viaja mais, apresentando uma sugestão de leitura acerca da globalização.

A figura 16 (página 103), intitulada A população das megacidades - 1950-2025, é constituída de quatro mapas iguais, com os continentes na cor verde. Cada um dos mapas indica a quantidade de megacidades no período - 1950, 1975, 2007 - de acordo com dados da ONU; e o último, 2025, trata-se de uma previsão da ONU acerca da quantidade de cidades globais que existirão. Os pontos vermelhos indicam a localização das megacidades, cujos nomes e percentual de habitantes são citados. 


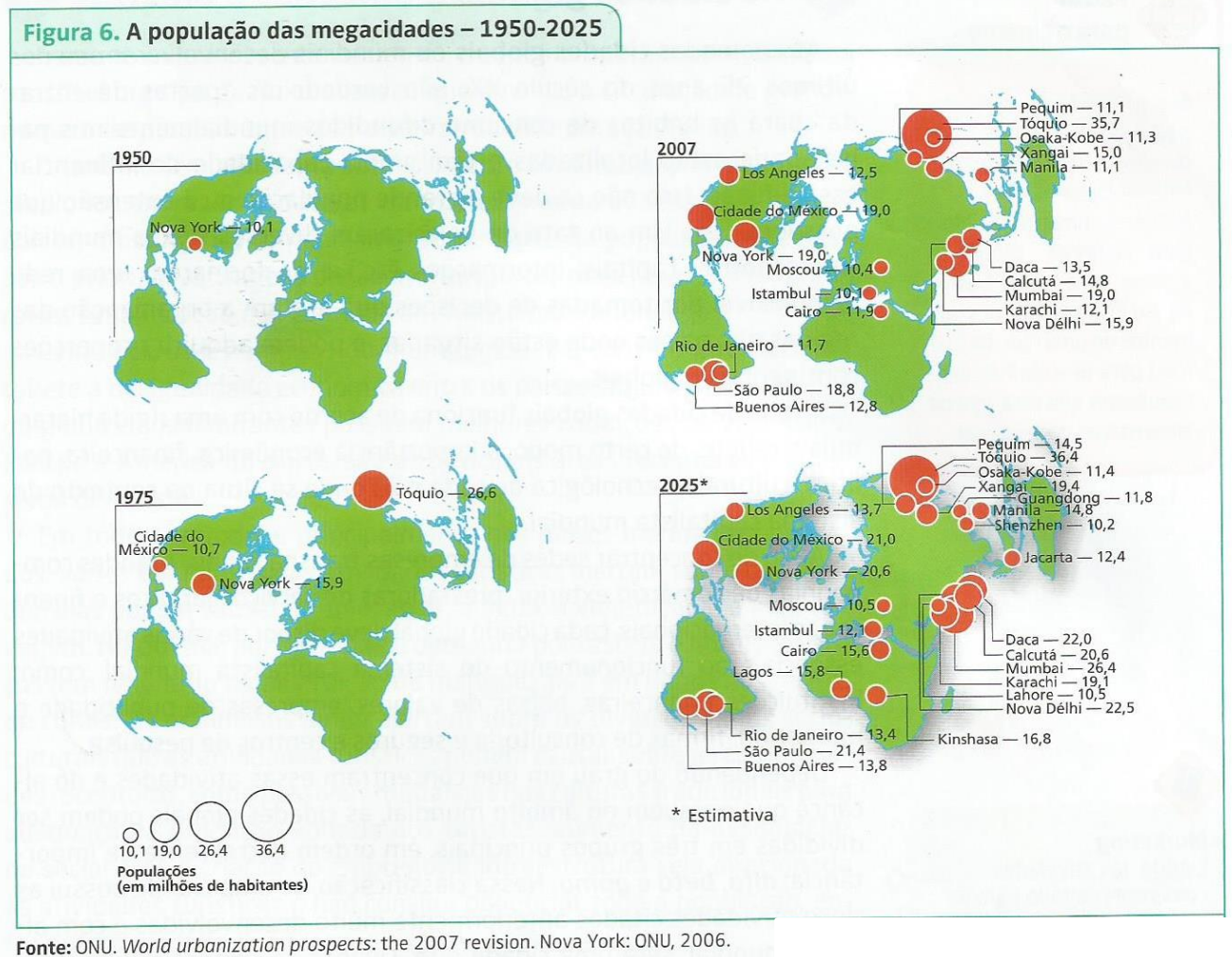

Figura 16: Mapa 1 do livro 2.

Fonte: livro Expedições Geográficas

Na página anterior à figura 16, no quarto parágrafo do texto principal, há as seguintes informações

Os problemas associados à urbanização serão mais graves nas megacidades e nas megalópoles - grandes aglomerações urbanas formadas por metrópoles ou grandes cidades cujos limites se interpenetram no espaço por elas ocupado (figura 6). Em 1950, Nova York era a única megacidade no planeta; em 2007, havia dezenove, a maioria concentrada nos países menos desenvolvidos industrializados, onde os problemas econômicos, sociais e ambientais são graves (desemprego, poluição, trânsito, violência, carência de transporte público, de saneamento, de serviços de saúde e de ensino básico de qualidade). Nas próximas décadas, os países emergentes serão os maiores geradores de megacidades, enquanto o crescimento desse tipo de aglomeração urbana nos países desenvolvidos tenderá à estabilização.

Observando o texto verbal e o texto visual, pode-se afirmar que a imagem acrescenta algumas informações ao texto, e o texto acrescenta outras informações à figura, conforme a comparação a seguir evidencia. 
Quadro 11: Informações em cada modo do capítulo no livro 2.

\begin{tabular}{|l|c|c|}
\hline Informações & Texto & Figura \\
\hline 1950 - uma megacidade - Nova York & Sim & Sim \\
\hline 1975 - três megacidades & não & Sim \\
\hline 2007 - 19 megacidades & Sim & Sim \\
\hline 2025 - previsão de 25 megacidades & Não & Não 20 \\
\hline Dados Estatísticos & Sim & Não \\
\hline $\begin{array}{l}\text { A maioria das megacidades se concentra emenos } \\
\text { desenvolvidos. }\end{array}$ & Sim & \\
\hline Os problemas econômicos, sociais e ambientais. & & Não \\
\hline $\begin{array}{l}\text { Os países emergentes serão os maiores geradores de megacidades. } \\
\text { estabilização. }\end{array}$ & Sim & Não \\
\hline
\end{tabular}

Fonte: elaborado pela autora com base em informações constantes no livro Expedições Geográficas.

Portanto, a relação existente entre o texto e a figura 16 é de complementariedade por acréscimo, pois ora a modalidade verbal acrescenta informações à modalidade visual, ora a modalidade visual acrescenta informações à modalidade verval. E isso corrobora afirmação de Ferraz (2016) $)^{22}$, que cada modalidade tem o seu potencial de significação.

Na página 62 também foi estabelecida uma relação de complementariedade entre o texto, que apresenta informações sobre as cidades globais e a figura 17 (página 105), que é um mapa intitulado Cidades globais. Enquanto no texto é apresentado o conceito de cidades globais e os critérios para a classificação em alfa, beta e gama são explicados, como se constata no seguinte fragmento

Dependendo do grau em que concentram essas atividades e do alcance que possuem no âmbito mundial, as cidades globais podem ser divididas em três grupos principais, em ordem decrescente de importância: alfa, beta e gama. Nessa classificação, se uma cidade possui as cinco atividades citadas anteriormente muito desenvolvidas e com alcance mundial, será uma cidade alfa. Quanto às cidades que contam com empresas de menor alcance mundial

\footnotetext{
${ }^{20}$ Caso o aluno não conheça os países considerados desenvolvidos e as principais cidades globais.

${ }^{21}$ Idem

${ }^{22}$ Citação feita pela Professora Doutora Janaína Aquino Ferraz, em aula durante o curso de Multimodalidade e Ensino, no primeiro semestre de 2016.
} 
ou mesmo apenas regional ou local, serão classificadas como beta e gama. Observe a figura 7.

no mapa, com os continentes em verde, as cidades globais são apontadas por meio de pequenas esferas coloridas, que constituem um código, cujo significado encontra-se na legenda, que informa os tipos de cidades globais.

Nessa figura, uma parte da imagem encontra-se salientada. E o fragmento em destaque representa a região do continente Europeu com as cidades globais, que são muitas, apontadas. De acordo com Kress e van Leeuwen (2006), há uma saliência enquadrada, porque, com a escala em que o mapa foi produzido, não haveria espaço para apontar todas as cidades. Portanto, esse detalhe consiste em complementariedade por acréscimo.

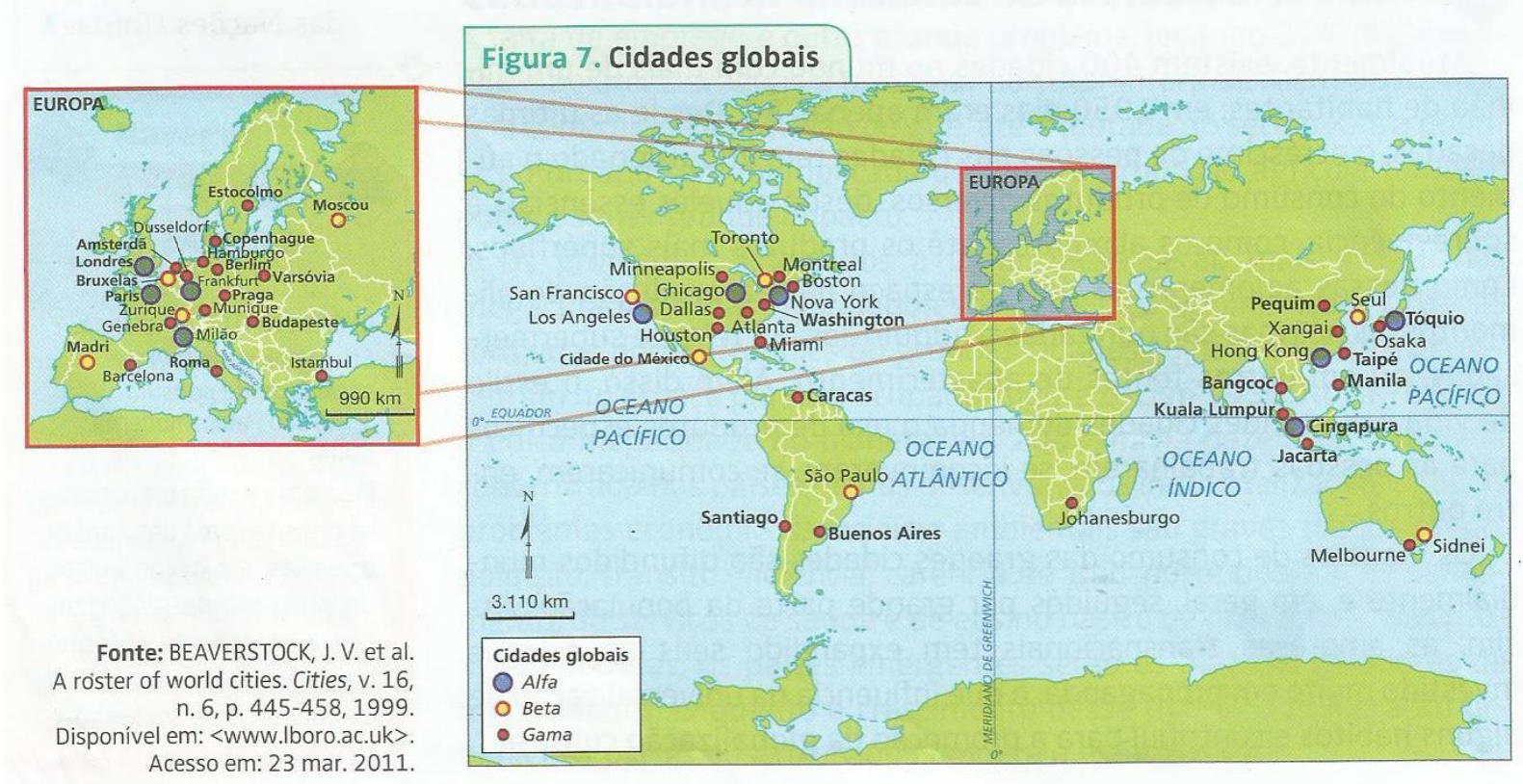

Figura 17: Mapa 2 do livro 2.

Fonte: livro Expedições Geográficas

Na última página de conteúdo, há a seção Turismo e consumo dos lugares, na qual são apresentadas explicações acerca do fluxo de pessoas pelo mundo e de consequências ambientais e socioculturais para as regiões que recebem muitos turistas. Em um fragmento de texto, encontram-se as seguintes declarações

Como outros fenômenos do mundo global, o turismo internacional reflete a desigualdade econômica entre os países (figura 8). As regiões do globo cujos habitantes possuem melhores condições de vida, como Europa e América do Norte, são as principais áreas receptoras e emissoras de turistas.

E, assim como os outros elementos visuais (16 e 17), a figura 18 (página 106) também expande os significados do texto, possibilitando que aluno observe as localidades que 
recebem mais turistas, as que recebem menos e, inclusive, as zonas com alto trânsito de cruzeiros turísticos.

De acordo com Kress e van Leeuwen (2006), as informações contidas no lado esquerdo da imagem ou do texto multimodal é o dado, informação já conhecida; e o que está ao do lado direito é a informação nova. Contudo, na figura 8 não é isso que se verifica, pois o mapa integral ficou à direita e a saliência, que é a informação nova partindo do mapa, ficou à esquerda.

Conectada ao mapa, há uma linha envolvendo um questionamento, que se trata de uma demanda de informação do autor, direcionada ao leitor (aluno)

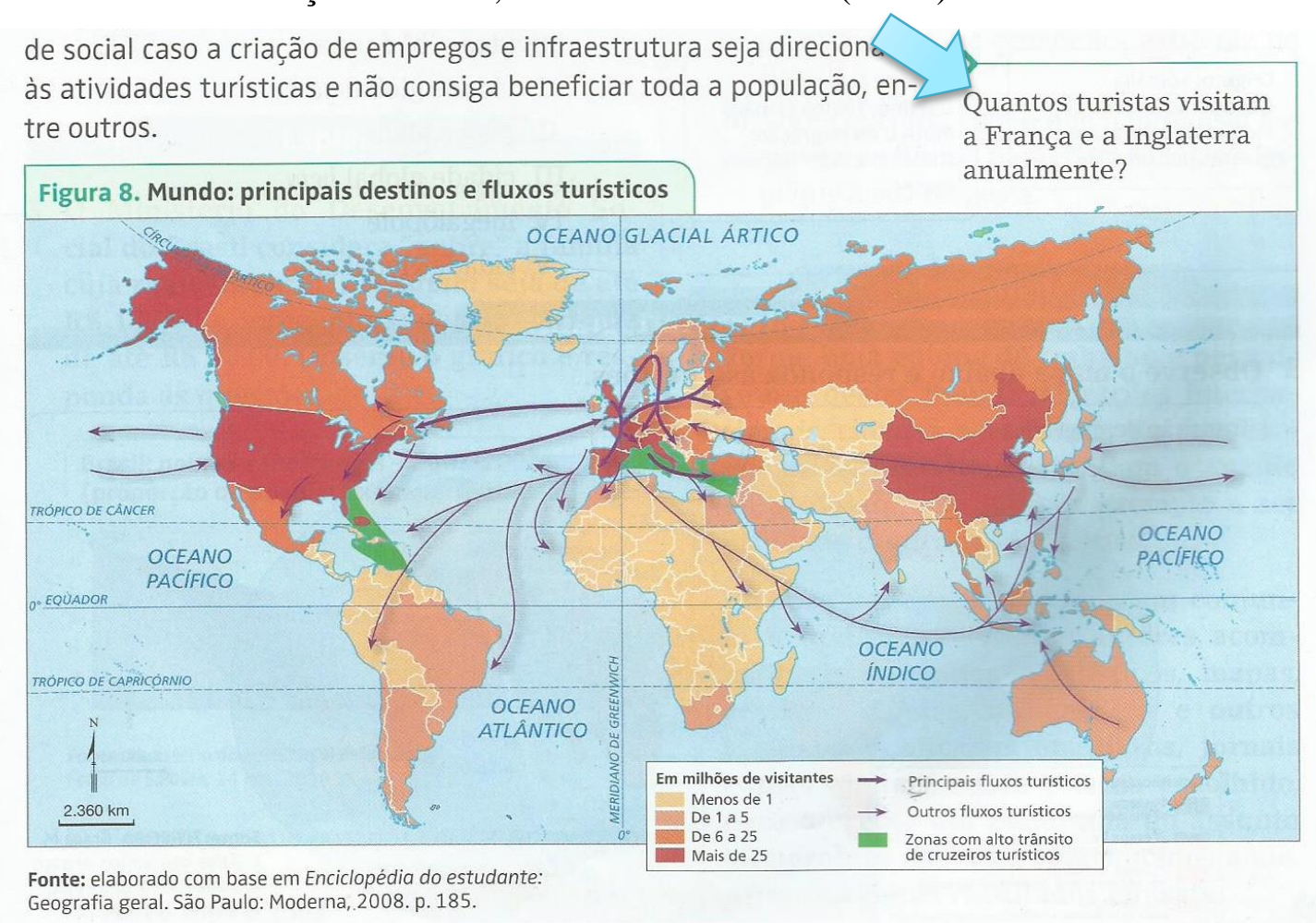

Figura 18: Mapa 3 do livro 2.

Fonte: livro Expedições Geográficas

\subsubsection{Modo Verbal - Livro 3}

O capítulo 12 do livro 3 é o mais extenso dos três capítulos analisados, por conter mais conteúdo verbal, maior variedade de recursos visuais e, também por conter atividade proposta no início do capítulo, antes da leitura, e após algumas seções.

Das 128 orações presentes no texto principal, 70 possuem sujeito em posição temática; 3, processo e 23, circunstância. Porém, em 49 orações há temas textuais, o que significa que muitas relações entre as orações foram construídas e colocadas em evidência, conforme se verifica no excerto a seguir 
A África, na verdade, desde o século XVI já participava desse mercado mundial, apesar de ainda não ser ocupada e dividida em colônias dos países europeus como ocorreu no século $X I X$,

pois inúmeros povos africanos recebiam bugigangas (algodão, rum, armas, joias de pouco valor)

e em troca [inúmeros povos africanos] forneciam para as potências europeias marfim, madeiras e principalmente escravos.

Mas foi com a Revolução industrial, iniciada em meados do século XVIII, que essa Divisão Internacional do Trabalho se consolidou,

[essa Divisão Internacional do Trabalho] se expandiu

$\boldsymbol{e}$ [essa Divisão Internacional do Trabalho] passou a ser em grande parte o que é até os dias de hoje.

Conforme se observa na figura, a página inicial do capítulo analisado no livro 3 é composta por diversos detalhes. Em destaque, devido à cor amarela e ao tamanho da fonte, no canto esquerdo há o símbolo de arroba, que representa a revolução tecnológica a partir do surgimento da internet. Ao lado desse símbolo, também se encontra em destaque o número do capítulo. A seguir, em fonte um pouco menor que a do símbolo e a do número do capítulo, há o título. Todos esses elementos encontram-se sobrepostos a uma imagem conceitual, cuja função, de acordo com Kress e van Leeuwen é a representação de identidades e atributos dos participantes.

A seguir, os autores apresentam o objetivo do estudo do capítulo, buscando envolver o leitor, por meio do uso da primeira pessoa. Abaixo do objetivo, encontra-se uma foto conceitual, na qual se vê parte de um porto repleto de containers empilhados, caixas e guindastes, acompanhada de sua legenda.

Em seguida, há um ícone simbolizando uma máquina fotográfica, seguido de um comando dividido em duas ações.

Para começar, observe a foto e responda:

$$
\underset{A c ̧ \tilde{a} \mathrm{o} 1}{A c ̧ \tilde{a} \mathrm{O} 2}
$$

Após o comando, encontram-se quatro informações demandadas pelos autores, a fim de resgatar algum conhecimento prévio do leitor. 


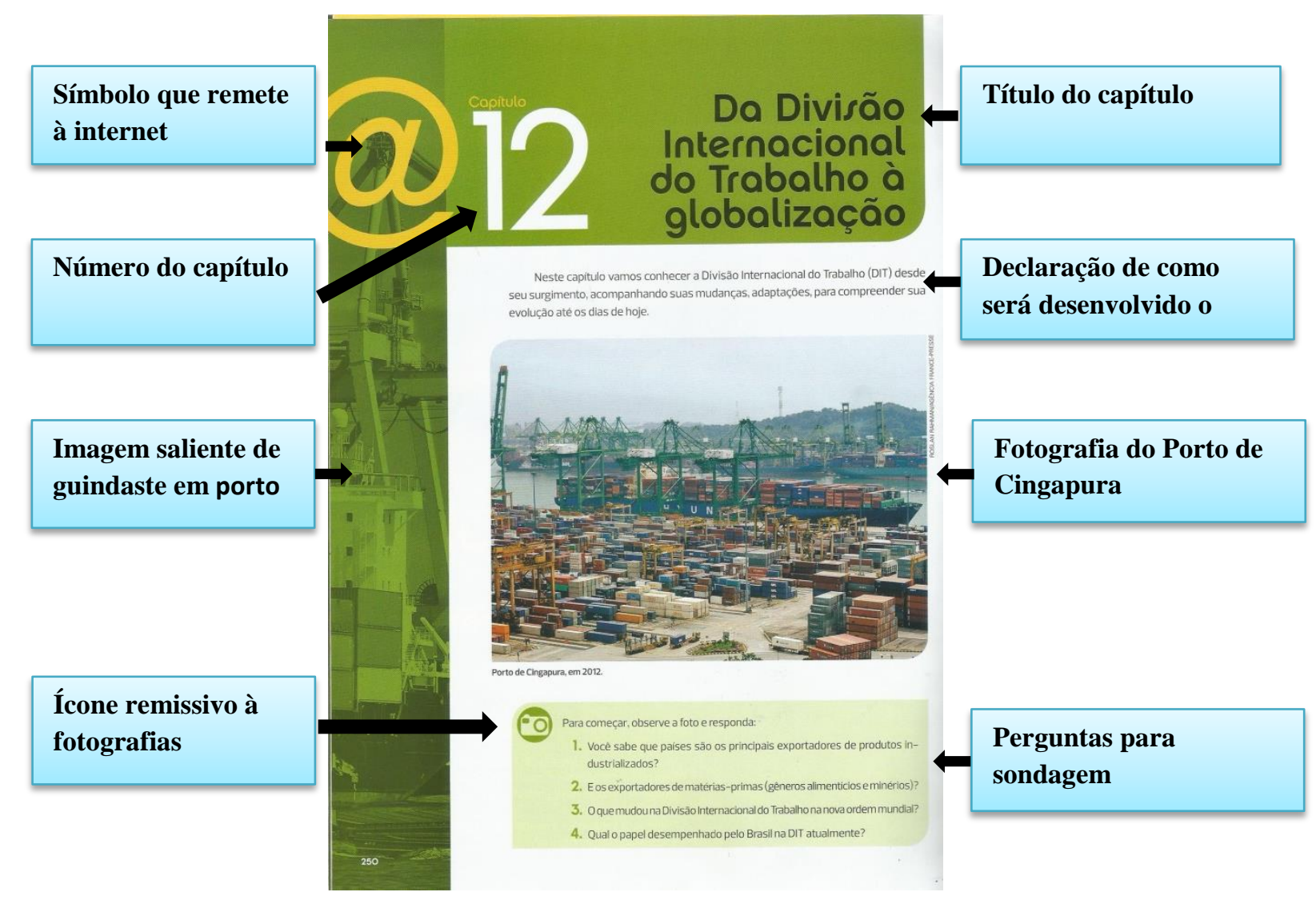

Figura 19: Página inicial do capítulo analisado do livro 3.

Fonte: livro Projeto Teláris

A seção Divisão Internacional do Trabalho é a primeira e encontra-se indicada pelo número 1 e salientada pelo tamanho da fonte e pela marcação em negrito. A seção Globalização é a segunda e também está sinalizada e destacada, porém, possui duas subseções: Expansão das multinacionais e Globalização e desigualdades internacionais.

As figuras do livro 3 não foram numeradas e apenas o mapa possui título. Porém, todas as figuras - desenho, mapa e fotos - possuem legendas.

$\mathrm{A}$ única seção lateral presente no capítulo 12 ocorre duas vezes. Ela chama-se $\mathbf{A Z} \mathrm{e}$ tem o nome representado por um pequeno ícone. Trata-se da apresentação de uma palavra presente no texto e de seu conceito, o qual os autores pressuponham ser desconhecido para os alunos.

Outra imagem diferente é a figura de um ícone geométrico e colorido com o número 7 abaixo. Porém, na apresentação do livro a explicação é dada da seguinte forma

Objeto Educacional Digital

Este ícone indica que há Objeto Educacional Digital disponível no DVD-ROM.

Ele irá aparecer numerado ao longo do volume. 
No final do livro, há uma lista dos objetos com sua respectiva função e as páginas em que se encontram.

Conforme a mensagem na apresentação do livro, na última página do livro do aluno, é apresentado um quadro com as informações e o Objeto Educacional que está relacionado ao tema globalização é

Quadro 12: Informações sobre o Objeto Educacional Digital $7^{23}$

\begin{tabular}{|l|l|l|l|}
\hline Número & Página & $\begin{array}{l}\text { Nome do conteúdo } \\
\text { multimídia }\end{array}$ & Comentário \\
\hline $\mathbf{7}$ & 254 & Globalização & $\begin{array}{l}\text { Jogo eletrônico educativo sobre as } \\
\text { características e as implicações de se } \\
\text { viver em um mundo globalizado. }\end{array}$ \\
\hline
\end{tabular}

Fonte: elaborado pela autora com base em informações constantes no livro Projeto Teláris.

\subsubsection{Relação entre os modos - livro 3}

A primeira seção explica o que foi a Divisão Internacional do Trabalho, como iniciou e quais as consequências para o mundo. E um dos fatores apresentados no texto, que contribuíram para mudanças no modo de produção, foram alguns inventos, como é afirmado no seguinte fragmento de texto

Como a produção se tornou possível graças à invenção de máquinas, como os teares mecânicos e a máquina a vapor, ambos inventadas nesse país, o Reino Unido conquistou o monopólio do desenvolvimento tecnológico. Também a existência de carvão mineral, principal fonte de energia no período, possibilitou que a industrialização se iniciasse no Reino Unido. Com isso, ele passou a exportar para os outros países da Europa e dos demais continentes produtos industrializados principalmente tecidos - fabricados em grande quantidade a baixo custo.

Ao final da página, encontra-se um desenho preto e branco (figura 20, página 110) representando uma tecelagem. É uma ilustração narrativa acional, pois há dois participantes trabalhando nos teares e um, aparentemente, posando para o ilustrador. Nesse caso, portanto, o contato daqueles é impessoal e deste, pessoal. Há uma distância social média, já que os participantes não foram registrados nem em close up - plano fechado - nem em long shot plano aberto. Observando a imagem cria-se um envolvimento maior com o participante que parece estar posando, e menor envolvimento como os outros participantes que estão de cabeça baixa, inclusive, uma mulher encontra-se de costas. E, em relação à composição, pode-se

\footnotetext{
${ }^{23}$ Não houve análise do Objeto Educacional Digital devido ao fato da pesquisadora não ter tido acesso à essa ferramenta.
} 
observar que todo o destaque foi dado ao tear, visto que um deles foi representado em primeiro plano, no centro da imagem, salientado pela cor branca, conforme se observa na figura 20 .

Concepção artistica de teares mecânicos com os quais o Reino Unido iniciou a Revolução Industrial no século XVIII.

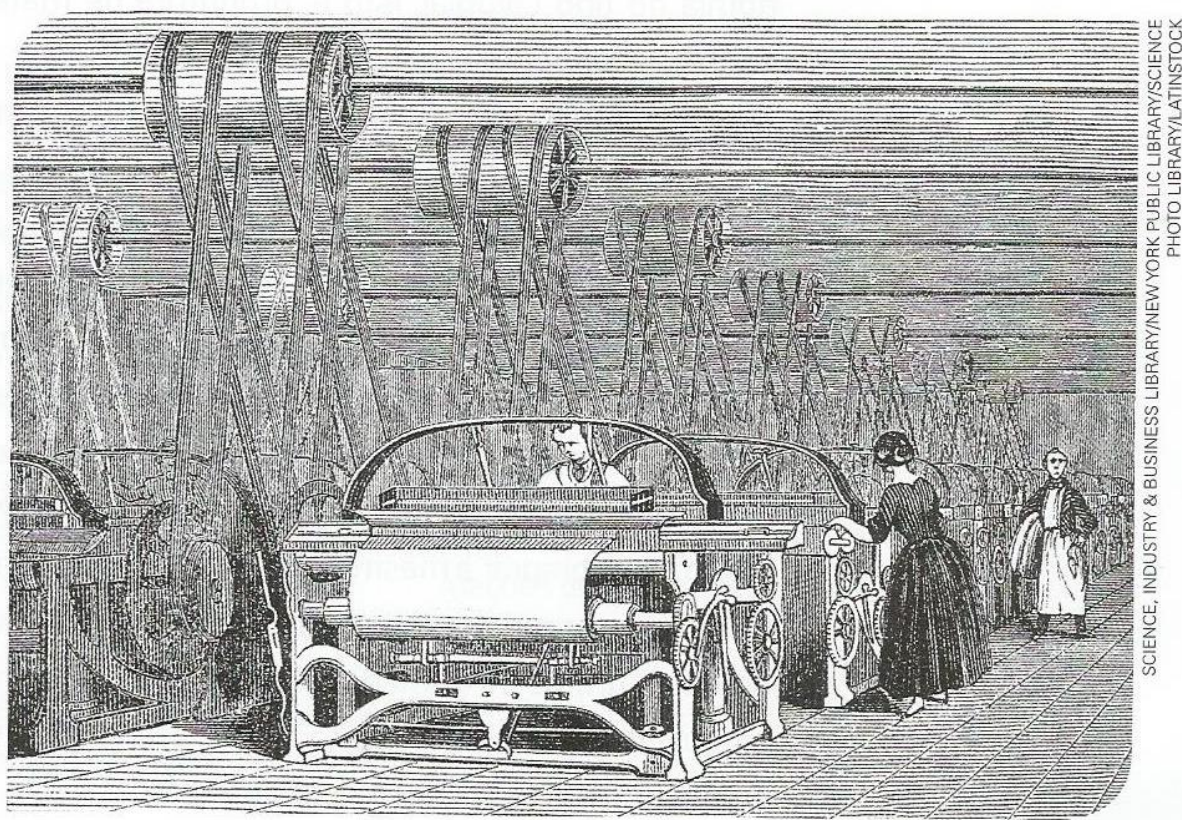

Figura 20: Desenho 1 do capítulo analisado no livro 3.

Fonte: livro Projeto Teláris

Como a imagem representa uma instância de tudo o que foi informado sobre a Revolução Industrial, segundo Unsworth (2006), trata-se de uma concordância com o texto por instanciação. E, em relação à legenda, também ocorre concordância, pois as informações contidas na imagem são uma instância de todas informações contidas no texto.

A segunda figura é um mapa intitulado A Divisão Internacional do Trabalho no seu auge, nos anos 1970 (figura 21, página 111) e, de acordo com a inscrição que se encontra em sua lateral esquerda, foi produzido pelos autores. As cores do mapa são suaves e a saliência encontra-se nas duas grandes setas vermelhas: uma representa o que a América do Norte exportava para a América do Sul - DIT clássica - e o que exportava nos anos 1970 - nova DIT; e a outra, o que a América do Sul exportava para a América do Norte - DIT clássica - e o que passou a exportar no auge da Nova DIT, conforme se verifica 


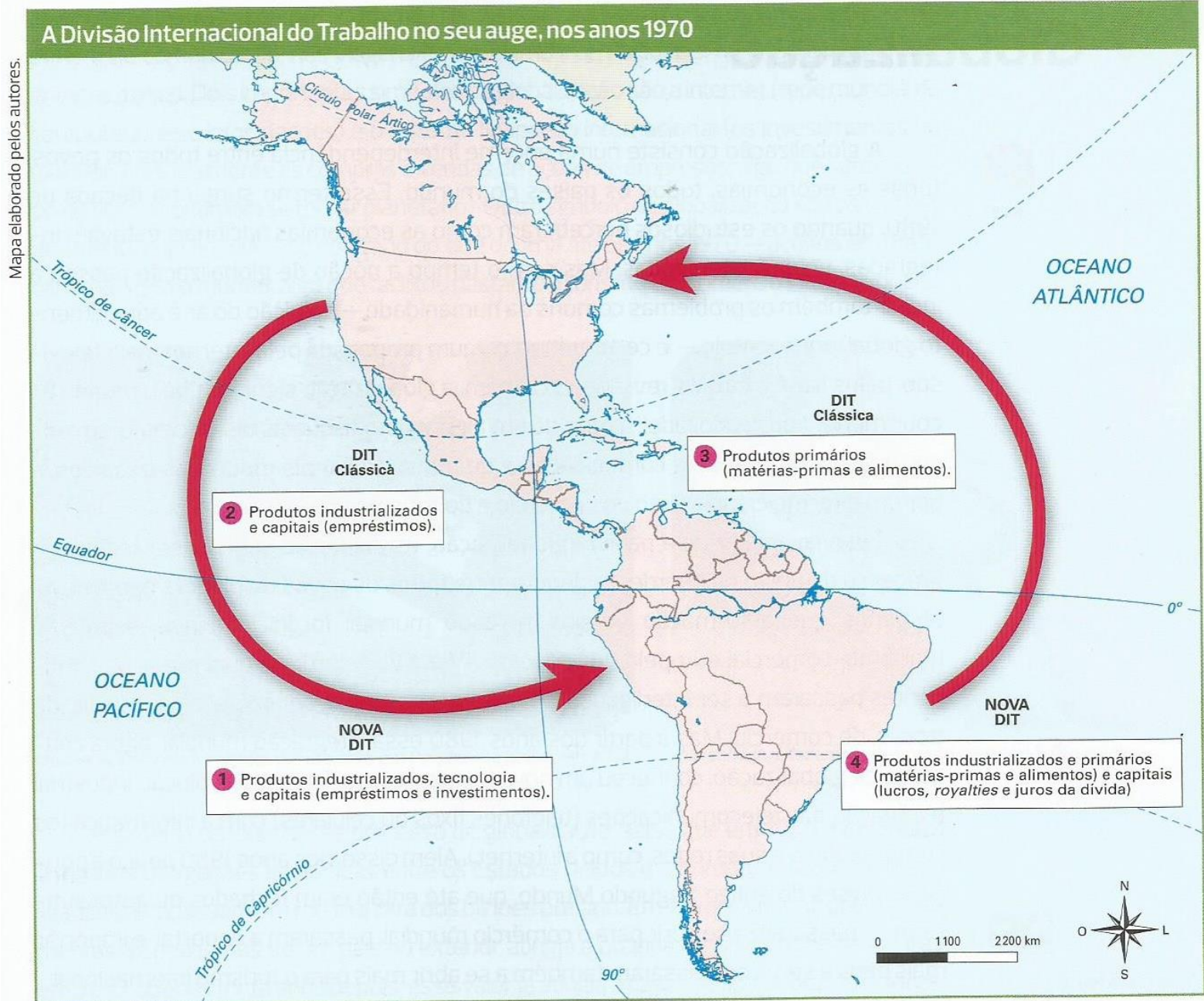

Desde os seus primórdios, no final do século XVIII, até por volta dos anos 1970 a Divisão Internacional do Trabalho consistia num comércio mundial marcado pela existência de dois grupos de países: os desenvolvidos e exportadores de bens industrializados e os subdesenvolvidos e exportadores de matérias-primas. Como veremos mais adiante, atualmente a Divisão Internacional do Trabalho, embora ainda exista, se tornou mais complexa e diversificada.

Figura 21: Mapa 1 do livro 3.

Fonte: livro Projeto Teláris

De acordo com as informações do texto e com a imagem, esta apresenta algumas informações que não constam naquele, logo há uma relação de complementariedade entre eles. E, no mapa são apresentados significados bem mais detalhados do que aqueles informados na legenda. Assim, esta também é complementada por aquele.

Na seção Globalização, verbalmente são apresentados diversos símbolos e mudanças, como se observa

Dois importantes símbolos da globalização são a internet (rede mundial de computadores e informações) e o sistema financeiro internacional (os investimentos no exterior, principalmente as compras e vendas de ações de empresas, algo que vai deixando de ser nacional para se tornar planetário). Outro símbolo da globalização são os cartões de crédito, hoje em dia - ao 
contrário do que ocorria até os anos 1970 - aceitos em praticamente todo o mundo, algo que facilitou bastante o turismo e o comércio internacionais.

E os autores utilizam duas fotografias, posicionadas lado a lado (figuras 22, p.112 e figura 23, p.113), representando esses importantes símbolos da globalização: a internet e o cartão de crédito. Então, essas imagens são instâncias do texto, porque de todas as informações verbais apresentadas, duas foram instanciadas por imagens.

A figura 22 é uma imagem narrativa acional, pois há uma participante usando um computador em um local semelhante a um restaurante ou lanchonete, onde estão outros participantes. Os vetores são as mãos da mulher junto ao computador. Ela foi retratada de lado, indicando certo distanciamento; e está um pouquinho acima do olhar de quem visualiza a foto, indicando uma relação de superioridade do participante envolvido com a tecnologia.

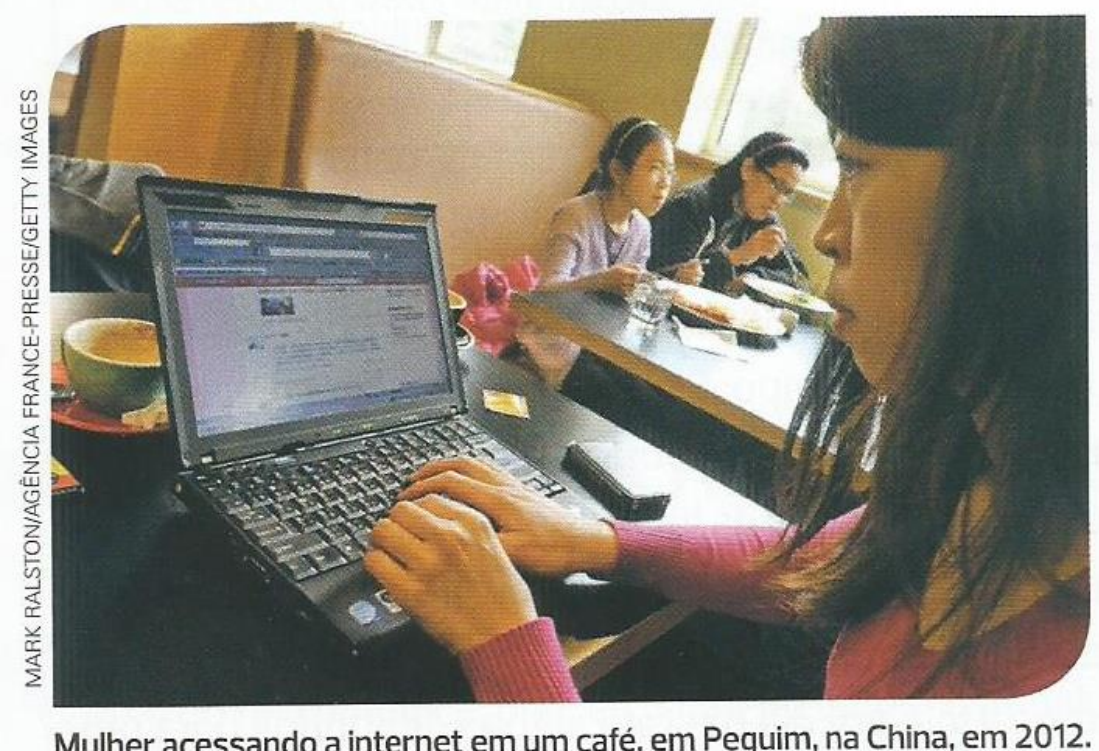

Figura 22: Fotografia apresentada no capítulo do livro 3.

Fonte: livro Projeto Teláris

A legenda logo abaixo da figura informa o seguinte

Mulher acessando a internet em um café, em Pequim, na China, em 2012.

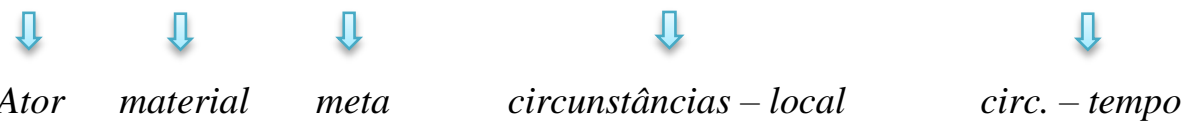

Então, imagem e legenda são concordantes, pois expressam tanto o modo verbal quanto o modo visual apresentam a informação de uma ação de uma participante no mundo físico.

A figura 23 


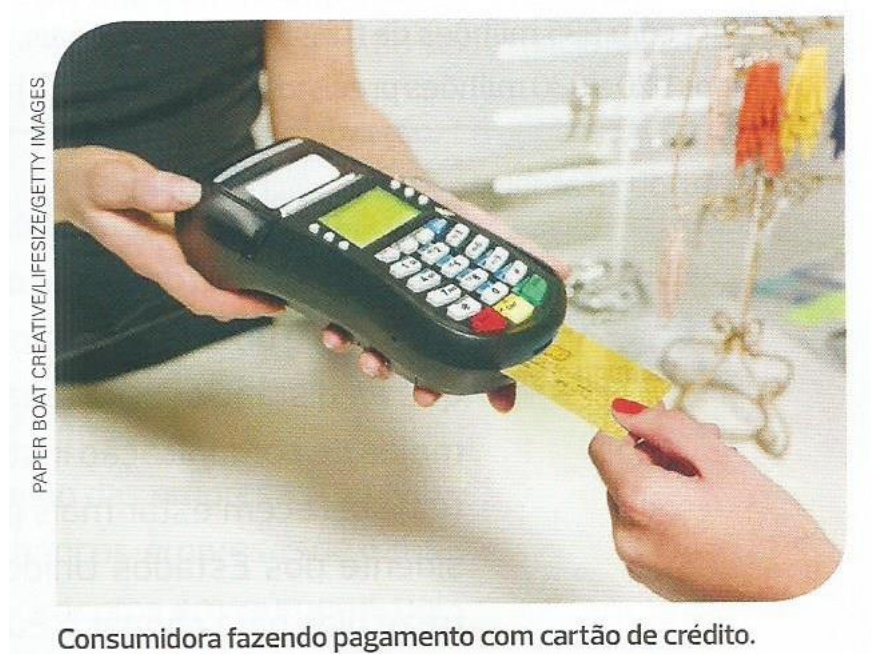

Figura 23: Fotografia 3 do livro 3.

Fonte: livro Projeto Teláris

é seguida da seguinte legenda

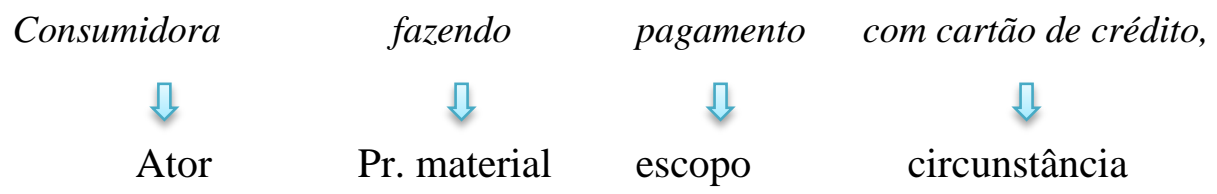

e o que se observa na figura é uma mão segurando uma máquina de cartão de crédito e outra mão segurando um cartão de crédito. Trata-se da representação de uma ação, com a presença de dois participantes e de vetor - a mão de um participante, conectada ao cartão, encaixado na máquina, segurada por outro participante. Assim, há concordância entre a imagem e a legenda, porque os dois modos apresentam informação cujos processos e participantes são os mesmos.

Em uma subseção intitulada Expansão das multinacionais, o surgimento de empresas transnacionais em diversos continentes é informado

Atualmente, calcula-se que mais de 55 mil empresas podem ser consideradas multinacionais, e elas controlam uma crescente fatia da economia mundial. Além disso, atualmente inúmeras empresas multinacionais importantes possuem sedes e capitais originários de países do Sul, como, Samsung, Daewoo, Hyundai, SK e LG, da Coreia do Sul; Sinopec, Sinopec Group, China National Petroleum, Lenovo e Bank of China, da China; Banco do Brasil, rede Globo e Petrobras, do Brasil; [...]

e logo abaixo encontra-se a figura 24 (página 114), com partes de uma esquadria com vidros sobreposta ao centro por uma placa com o logotipo do Banco do Brasil. Essa foto é uma 
imagem conceitual, pois, a parte - o logotipo - representa o todo - a empresa e não há participantes nem vetores. E nesse caso, a imagem é uma instância do texto.

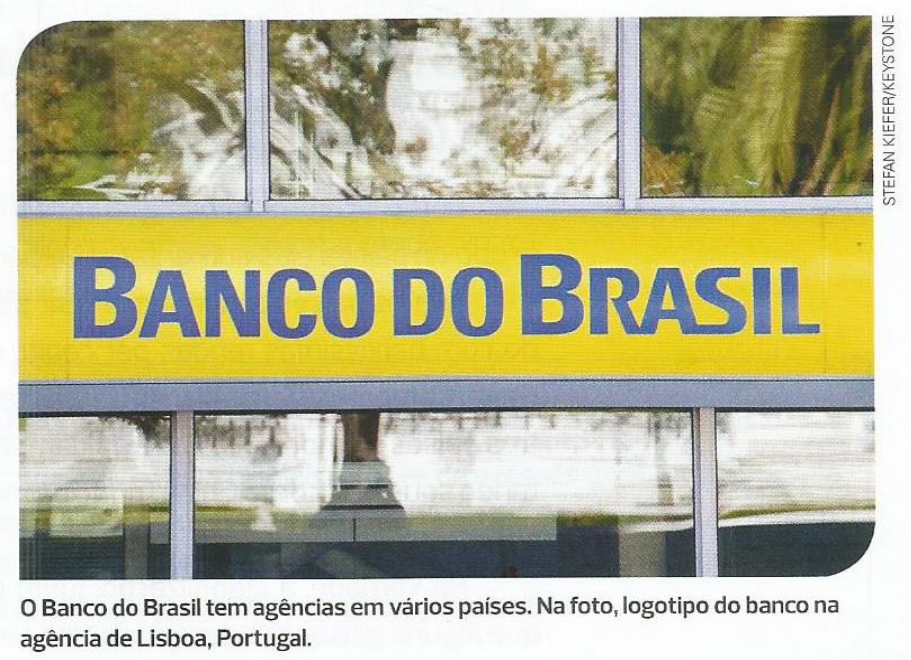

Figura 24: Fotografia 4 do livro 3.

Fonte: livro Projeto Teláris

A legenda que acompanha a figura 24 contém duas informações: uma delas complementa o significado da fotografia, porque informa que

O Banco do Brasil tem agências em vários países.

E a outra expande a foto, porque afirma o seguinte:

Na foto, logotipo do banco na agência de Lisboa, Portugal.

Como na figura 24 não dá para identificar o lugar onde a imagem foi produzida, a informação de que se trata de uma agência de Lisboa é complementar.

Ao afirmarem que

A globalização, com a aceleração do ritmo do tempo e com suas novas tecnologias, permitiu uma rápida expansão de algumas economias que antes eram tidas como pobres ou subdesenvolvidas e que hoje já disputam em condições de igualdade com os países do Norte: China, principalmente, além de Coreia do Sul, Taiwan, Cingapura e até mesmo Índia (apesar da persistência de enormes bolsões de pobreza), Brasil e outros países do Sul.

em seguida se observam três fotos muito semelhantes (figura 25, página 115). Na primeira, pode-se ver um homem empurrando um pneu em uma fábrica. Logo, se trata de imagem narrativa acional. Na segunda, o todo - fábrica de automóveis - é representada pela parte carro em destaque no centro da figura -; assim, tem-se uma imagem conceitual. E, na terceira e última, há a representação de várias pessoas trabalhando em uma fábrica de automóveis. 
Participantes e carros estão conectados e, em primeiro plano, há um participante em destaque, elevando sua mão em direção a um carro também em destaque. Então, como há um espaço, com participantes, vetores, trata-se de outra narrativa acional.

As legendas são concordantes com as imagens que, por sua vez, expandem as informações do texto principal, com especificações sobre os tipos de empresas que surgiram nos antigos países pobres ou subdesenvolvidos.

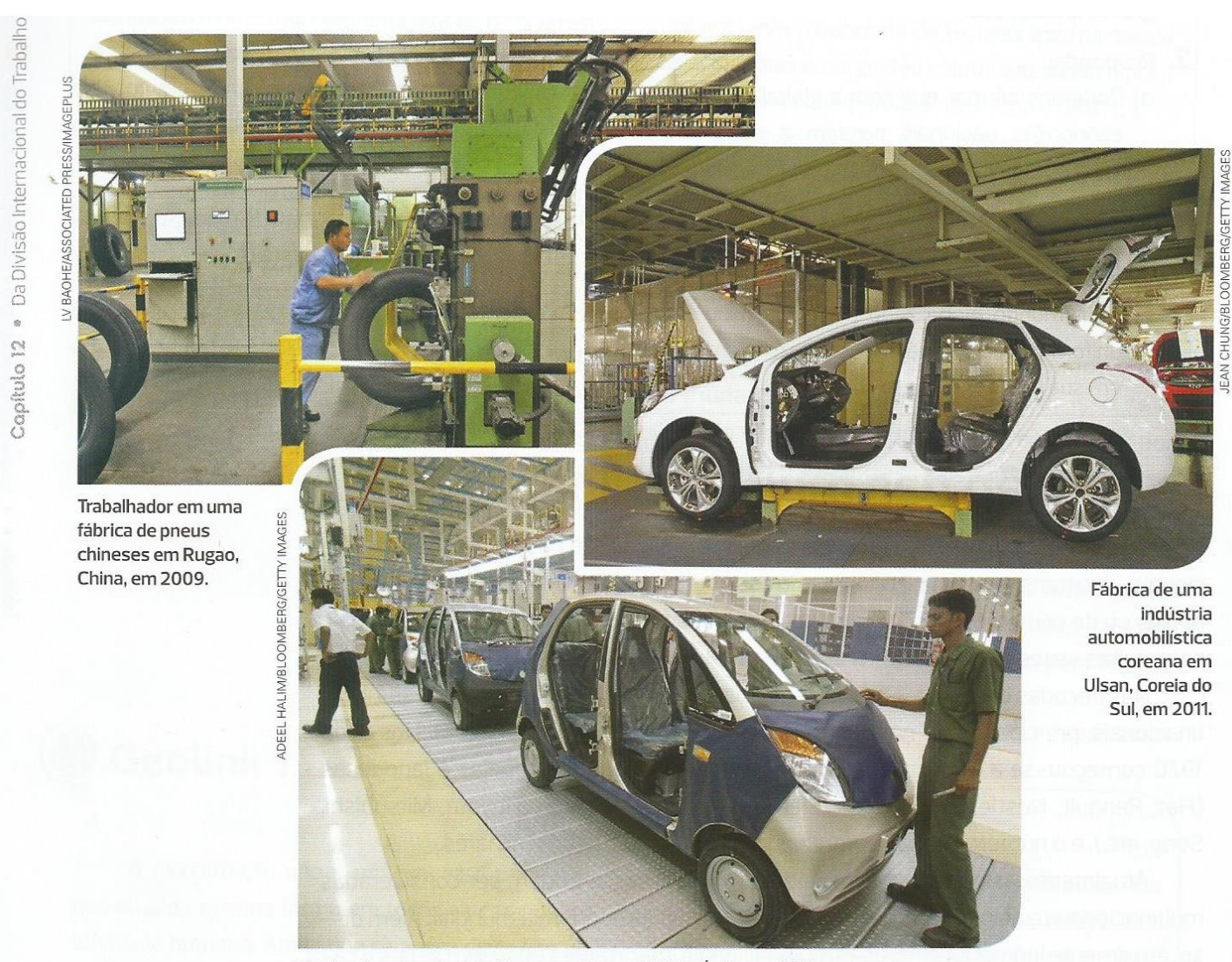

Figura 25: Fotografias 6, 7 e 8 do livro 3.

Fonte: livro Projeto Teláris

Conforme afirmação na página 108, a seção AZ ocorre duas vezes: uma com a palavra autossuficiente (figura 26, página 116) e outra com o grupo nominal Mercado consumidor potencial. No texto, as duas expressões foram grafadas na cor verde e, no espaço ao lado delas - lateral - a seção contendo o significado é posicionada. Então, a cor verde salienta a expressão desconhecida e, ao lado, encontra-se a explicação, conforme o exemplo

Ex. 


\begin{abstract}
Todavia, apesar de a palavra globalização, usada nesse sentido, ser recente, o processo de união ou interdependência entre todos os povos do planeta não é novo. Já vimos que a formação de um mercado mundial foi iniciada pela expansão marítimo-comercial europeia dos séculos XV e XVI, a partir da qual todos os continentes passaram a ser interligados, passaram a participar de um sistema mundial de trocas, de comércio. Mas a partir dos anos 1980 essa integração mundial, agora chamada de globalização, conheceu um novo impulso com a Terceira Revolução Industrial e a ligação das telecomunicações (telefones fixos ou celulares) com a informática (os computadores e suas redes, como a internet). Além disso, nos anos 1980 pouco a pouco os países do antigo Segundo Mundo, que até então eram fechados ou autossuficientes, passaram a se abrir para o comércio mundial, passaram a exportar e importar mais bens e serviços, passaram também a se abrir mais para o turismo internacional.

Com a globalização, as economias nacionais passam a depender cada vez mais do mercado mundial. Elas deixam de ser relativamente isoladas e passam a ser muito mais integradas. Com isso, uma crise que ocorre num país ou numa região remota do globo logo repercute - isto é, produz consequências - em praticamente todo o mundo. Isso porque todas as economias estão integradas, e uma crise econômica num país, por exemplo, da Europa logo produz retração nas exportações de inúmeros países (que vendem produtos para a Europa), e assim sucessivamente.
\end{abstract}

Figura 26: fragmento de texto e seção lateral

Fonte: livro Projeto Teláris

\subsection{OS GÊNEROS TEXTUAIS}

Todas as descrições e análises das metafunções - ideacional, interpessoal e textual contribuem para a identificação dos gêneros que compõem os capítulos dos livros didáticos investigados, pois dentro das possibilidades disponíveis nos sistemas - Transitividade, MODO e modalidade e Estrutura Esquemática - escolhas léxico-gramaticais foram feitas, e essas, além de significarem o contexto de situação, por meio das variáveis de campo, relações e modo - variáveis de registro -, permitem que os gêneros possam ser definidos, pois, segundo Martin e Rose (2008, p. 16), cada gênero envolve uma configuração particular dessas variáveis.

Para afirmar os gêneros que predominam nos textos analisados, primeiramente, é necessário observar o propósito, e assim, chegar ao recorte da família, reduzindo bastante o universo de gêneros que, conforme Martin e Rose afirmam (2008, p. 17), "as culturas parecem envolver um amplo, mas potencialmente definível conjunto de gêneros, que são reconhecíveis aos membros de uma cultura, ao invés de uma selva imprevisível de situações sociais." Dessa forma, é possível afirmar que os gêneros textuais presentes nos capítulos analisados possuem características linguísticas que permitem que eles sejam encaixados na família das Explicações, cujo propósito é explicar algum evento.

De acordo com Muniz e Silva (2015, p. 28), a família das Explicações é constituída pelos gêneros: explicação sequencial, condicional, fatorial e consequencial. Então, foi 
necessária a observação mais detalhada das características linguísticas para uma afirmação mais precisa. E a ferramenta que auxiliou essa etapa da descrição foi a topologização dos gêneros, que é uma forma de representação gráfica de dimensões do texto, utilizada por Martin e Rose (2008) para propiciar a visualização das características do texto, conforme se verifica nas figuras 27 e 28.

É importante ressaltar que essa forma de representação das características é bidimensional, ou seja, só permite que duas dimensões sejam visualizadas. Então, foi necessária a utilização de mais de uma figura representante da topologia, como se observa a seguir

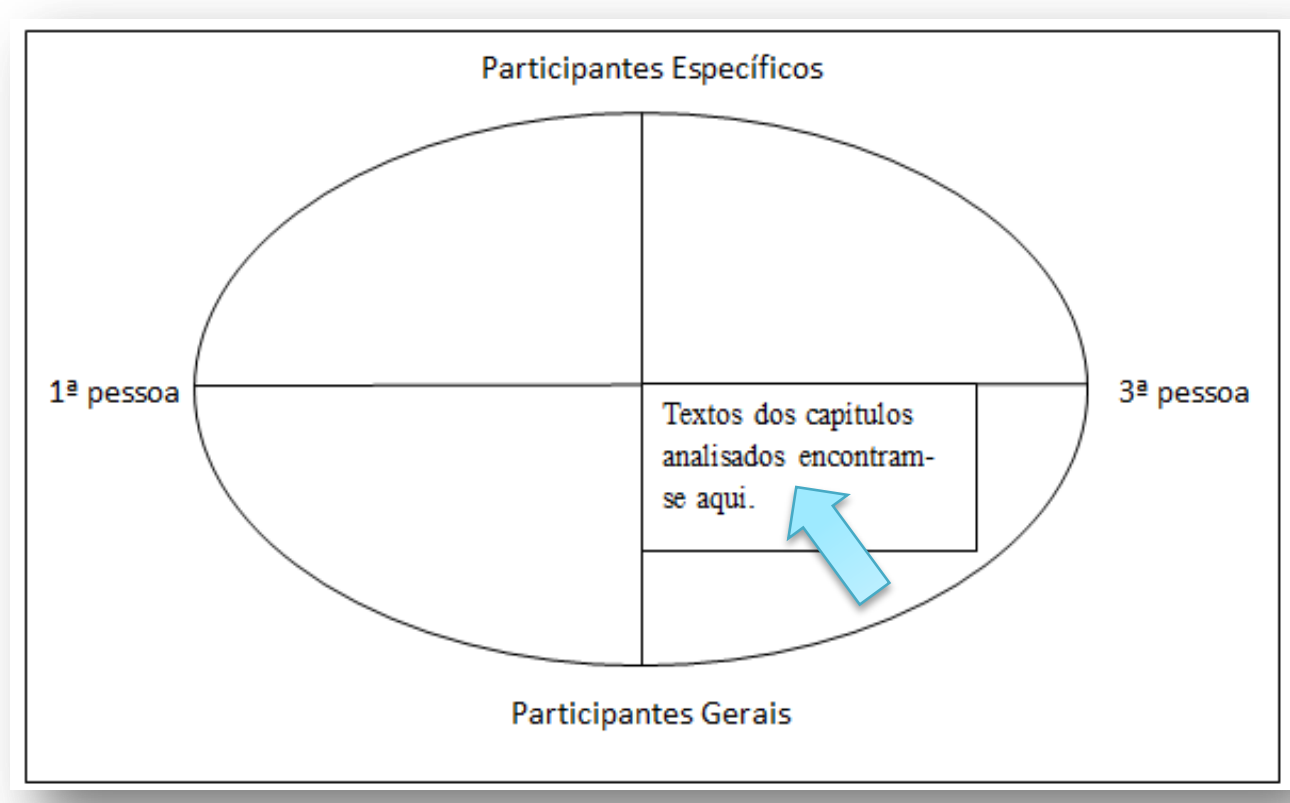

Figura 27: Visualização das pessoas do discurso e dos tipos de participantes.

Fonte: elaborado pela autora com base em Martin e Rose (2008) 


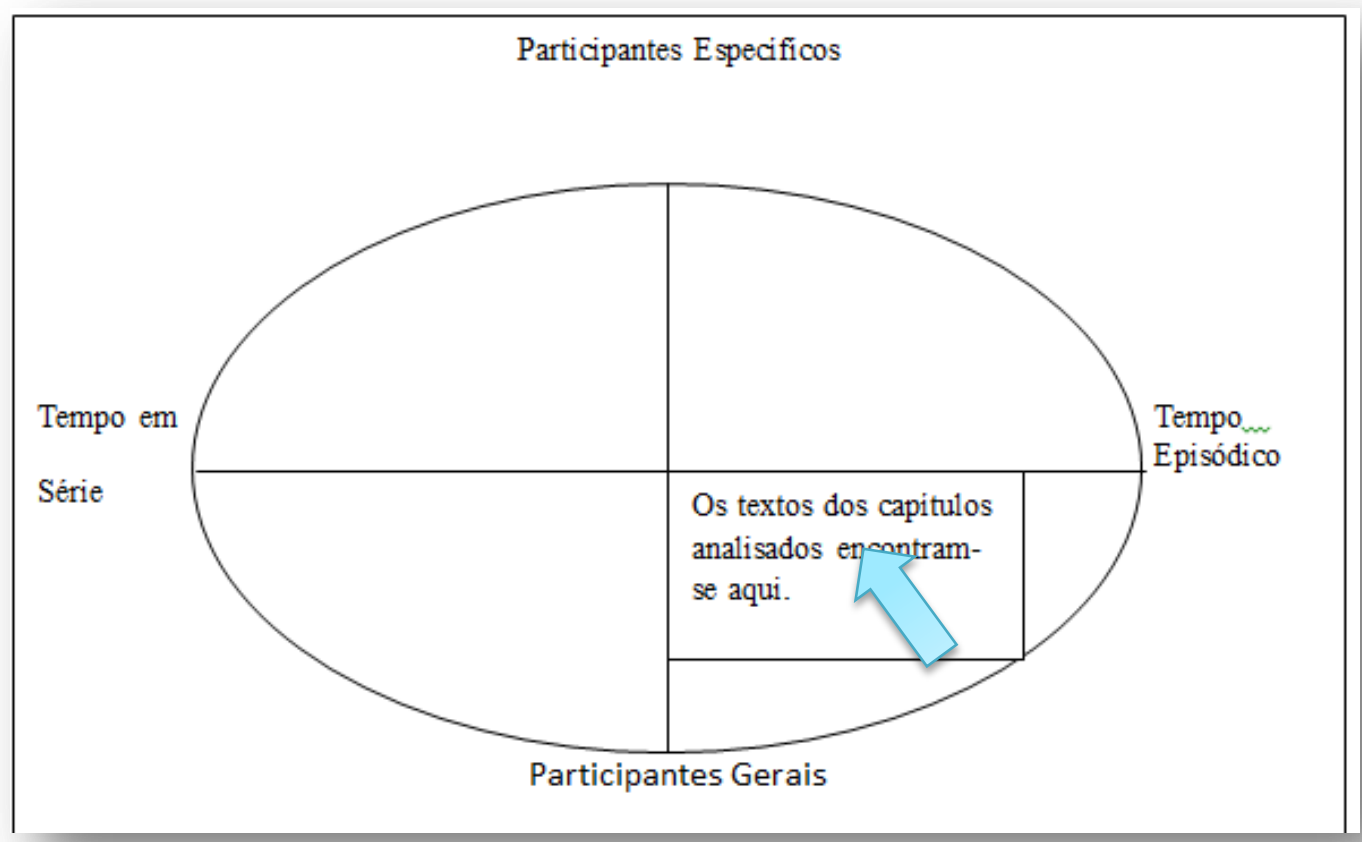

Figura 28: Visualização dos tipos de participantes e dos tipos de tempos.

Fonte: elaborado pela autora com base em Martin e Rose (2008)

A figura 27 demonstra que nos textos escritos foram predominantemente utilizados a terceira pessoa, bem como os participantes genéricos, então não se trata de autobiografia recontagem de eventos da vida do próprio autor do texto, em que predominam a primeira pessoa e participantes específicos -; nem de biografia - escrita em terceira pessoa, porém envolvendo participantes específicos.

E a figura 28 demonstra que o tempo episódico prevalece nos textos, reforçando que não se trata de representações de sequências de eventos, mas de representação de fases, que, às vezes, podem ser sequenciadas.

De fato, há a utilização de diversas circunstâncias, quando foram descritas as representações dos acontecimentos, diversas circunstâncias foram identificadas; Todavia, não são apenas as referências de tempo que estão em destaque, pois os autores foram além dos relatos, ora apresentando relações simples de causa e consequência, ora especificando os fatores que determinaram um evento, ora detalhando as consequências de um evento, como se verifica no exemplo do quadro 13. 
Quadro 13: Fatores determinantes para um evento.

\begin{tabular}{|c|c|c|}
\hline 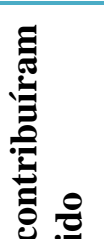 & $\begin{array}{l}\text { Como a produção industrial se tornou possível graças à invenção } \\
\text { de máquinas, como os teares mecânicos e a máquina a vapor, } \\
\text { ambos inventadas nesse país, o Reino Unido conquistou o } \\
\text { monopólio do desenvolvimento tecnológico. }\end{array}$ & $\begin{array}{l}\text { dois fatores que } \\
\text { contribuíram } \\
\text { para o monopólio }\end{array}$ \\
\hline 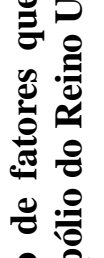 & $\begin{array}{l}\text { Também a existência de carvão mineral, principal fonte de energia no } \\
\text { período, possibilitou que a industrialização se iniciasse no Reino } \\
\text { Unido. }\end{array}$ & mais um fator \\
\hline 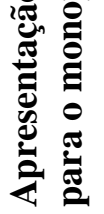 & $\begin{array}{l}\text { Com isso, ele passou a exportar para os outros países da Europa e dos } \\
\text { demais continentes produtos industrializados - principalmente tecidos } \\
\text { - fabricados em grande quantidade e a baixo custo. }\end{array}$ & consequência \\
\hline
\end{tabular}

Fonte: elaborado pela autora

Nesse caso, as relações causais são mais evidentes do que as relações apresentadas pelas circunstâncias, o que permite afirmar que se trata de Explicações.

A falta de assertividade em um primeiro momento pode ser justificada pelo fato de a linha divisória entre o relato histórico e as explicações ser muito tênue, porque de acordo com Martin e Rose

Embora a sequência se torne uma questão de textura, a causalidade continua a ser uma questão do que causou o que no mundo. Em certo sentido, as explicações são simplesmente relatos complicados em que mais de uma coisa leva a outra ou a partir de outra. (MARTIN E ROSE, 2008, p. 131)

Às vezes há uma relação simples de causa e consequência, indicando uma explicação sequencial

$$
\text { Causa } \Rightarrow \text { consequência }
$$

\section{Quadro 14: Explicação sequencial}

Como as migrações internacionais, o turismo internacional também constitui um tipo de fluxo mundial

que envolve a circulação de grande número de pessoas entre as fronteiras de diferentes Estados.

Conforme se observa no exemplo acima, um fator contribui para um fenômeno. 
As explicações que apresentam fatores que culminaram em um evento são classificadas como fatoriais.

Ex.

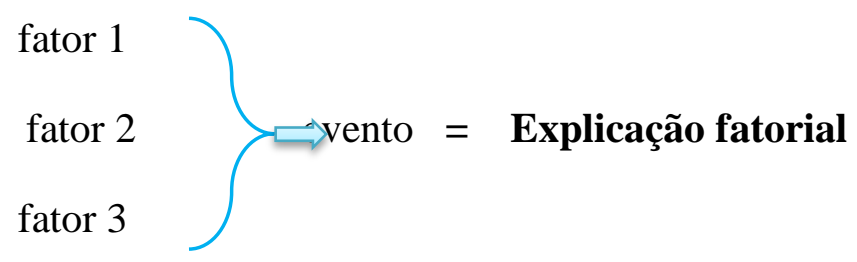

Figura 29: Exemplo de taxonomização de uma explicação fatorial.

Fonte: elaborado pela autora

\section{Quadro 15: Explicação fatorial}

$O$ turismo tem apresentado crescimento contínuo desde meados do século $\mathrm{XX}$, em razão de fatores como:

crescimento da renda em muitos países;

mudança no comportamento de parte da população, que passou a priorizar as viagens de lazer;

transportes mais rápidos e mais baratos;

simplificação dos trâmites em fronteiras e alfândegas.

Fonte: elaborado pela autora

Em algumas explicações, conforme a taxonomização demonstra e o fragmento de texto exemplifica, vários fatores contribuem para desencadear um fenômeno.

As explicações que apresentam consequências oriundas de um determinado evento são classificadas como consequenciais.

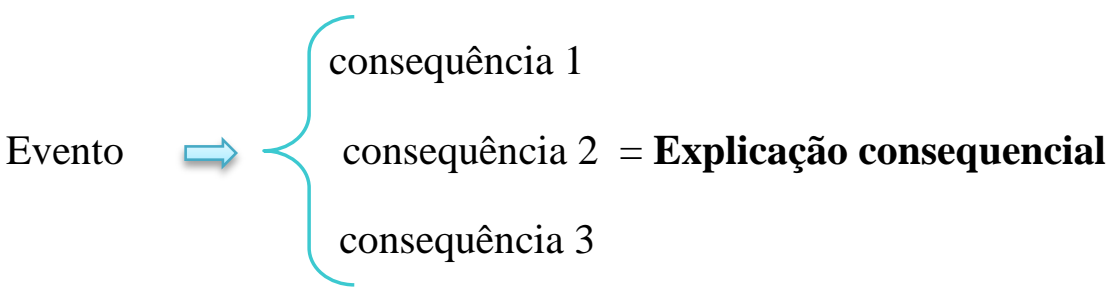

Figura 30: Exemplo de taxonomização de uma explicação consequencial

Fonte: elaborada pela autora 


\section{Quadro 16: Explicação consequencial}

\begin{tabular}{l}
$\begin{array}{l}\text { Além disso, nos anos } 1980 \text { pouco a pouco os países do antigo Segundo Mundo, que até então } \\
\text { eram fechados ou autossuficientes, passaram a se abrir para o comércio mundial, }\end{array}$ \\
\hline passaram a exportar \\
\hline e importar mais bens e serviços, \\
passaram também a se abrir mais para o turismo internacional.
\end{tabular}

Fonte: elaborado pela autora.

E em algumas ocorrências, um evento desencadeia várias consequências.

A perspectiva topológica de Martin e Rose (2008) mais uma vez é utilizada com o objetivo de demonstrar em que aspectos relatos e explicações se aproximam e em que aspectos se distanciam

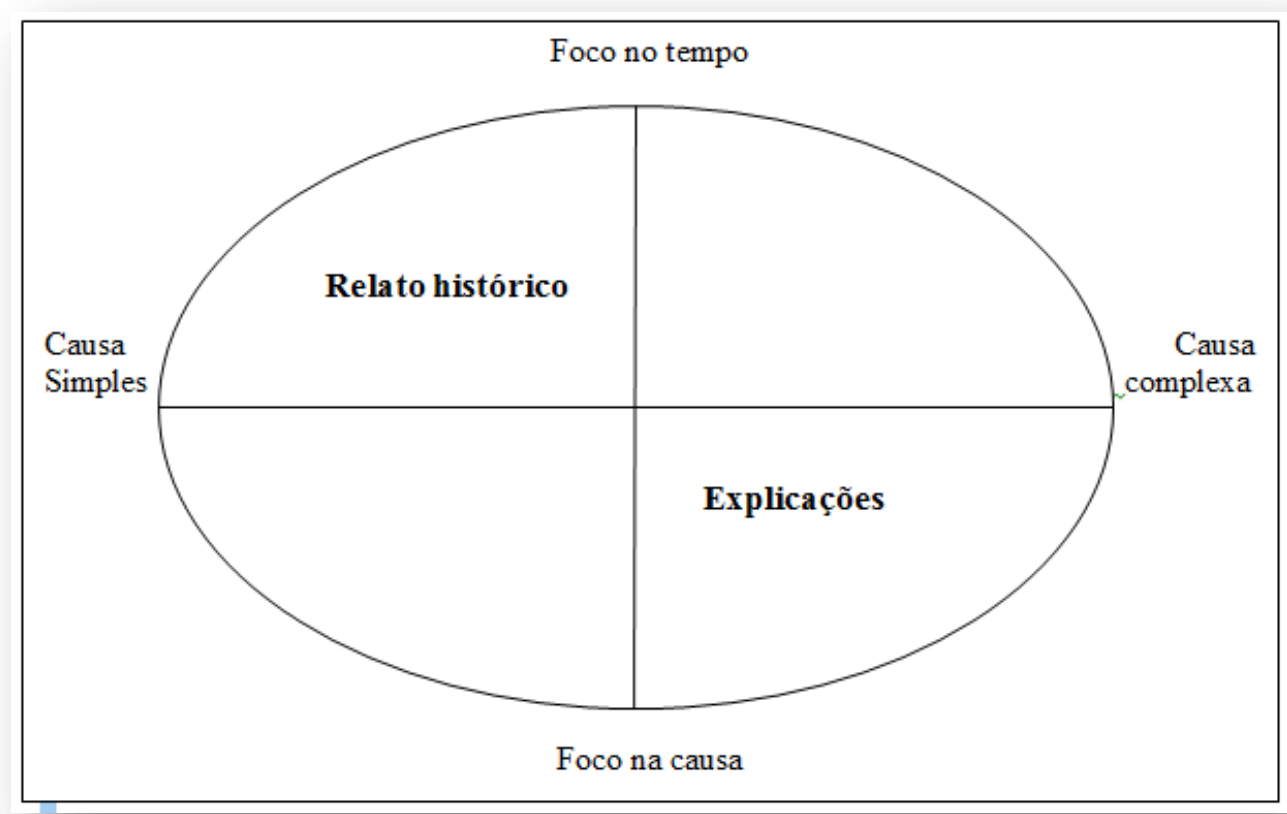

Figura 31: Topologização

Fonte: elaborada pela autora, inspirada em figura 3.7 (MARTIN e ROSE, 2008, p. 131)

De acordo com Martin e Rose (2008), “em explicações por escrito, as relações causais podem não ser percebidas explicitamente com conjunções causais como 'porque, assim, portanto ', mas pode ser implícita no gênero explicação".

A definição das explicações com base em elementos explícitos como conjunções explicativas e causais estão presentes nos textos das seguintes formas.

Ex. 
Isso porque todas as economias estão integradas, e uma crise econômica num país, por exemplo, da Europa logo produz retração nas exportações de inúmeros países (que vendem produtos para a Europa), e assim sucessivamente. (conjunção explicativa)

Como nessas aglomerações não há espaço para a produção de alimentos, as pessoas são obrigadas a adquiri-los em feiras e supermercados, ou em outras fontes de abastecimento.

E o mercado, graças exatamente à ciência e à técnica, torna-se um mercado global.

Entretanto, de acordo com Martin e Rose,

[...] a causa pode, naturalmente, ser realizada entre através de conjunções (por exemplo, a explicação fatorial [3: 8] acima), mas como temos indicado, na explicação tende a ser realizada dentro da oração através de substantivos, verbos e preposições. Para que isso aconteça, um ou ambos os eventos que estão sendo conectados têm que ser nominalizados a fim de funcionarem dentro da cláusula como participantes ou circunstâncias. Consequentemente, as explicações históricas baseiam-se na metáfora gramatical muito mais fortemente do que os relatos históricos (embora por razões de empacotamento temporal, relatos históricos já estejam se movendo nesse sentido). Uma vez que a metáfora gramatical é um recurso para leitura e escrita que se desenvolve após a puberdade no ensino secundário, o movimento de relato para explicação é muito significativo no desenvolvimento de aprendiz de historiadores. (MARTIN e ROSE, 2008, p. )

Ex.

A globalização pode ser entendida como o conjunto de transformações recentes na economia do planeta, que causaram uma ampliação dos fluxos de mercadorias, uma integração entre os países.

Em todo o mundo, e principalmente nos países menos desenvolvidos, vários estudiosos das atividades turísticas alertam sobre os danos que elas podem causar ao solo, ao ar, à água, à vegetação e à vida selvagem.

Foi com a Primeira Revolução Industrial que se estabeleceu essa Divisão Internacional do Trabalho.

A globalização, com a aceleração do ritmo do tempo e com suas novas tecnologias, permitiu uma rápida expansão de algumas economias [...]

A divida externa fez com que diversos países fossem forçados a seguir exigências de organizações mundiais, como o FMI, o que gerou a flexibilização de regras de proteção à sua indústria e a privatização de setores importantes da economia, [...] 
A falta de emprego é outro problema, levando $37 \%$ dos moradores de áreas urbanas a trabalhar no ser informal.

Desde as últimas décadas, o acréscimo de pessoas nas cidades tem impulsionado o aumento do consumo de produtos diversos, desde aqueles essenciais à sobrevivência, como os alimentos, até os produtos mais supérfluos.

Em muitos casos provocou uma diminuição no uso da mão de obra, [...]

por meio de substantivos

ex.

A difusão do capitalismo pelos então países socialistas levou a um aumento das trocas econômicas e ao acirramento da concorrência internacional.

Tradicionalmente, a Divisão Internacional do Trabalho é marcada pela existência de dois principais grupos de países:[...]

Além disso, o estilo de vida nas grandes cidades demanda o uso de produtos específicos para as pessoas trabalharem [...]

[...] e investido muito em propaganda, o que influencia na universalização de alguns hábitos e contribui para a promoção da globalização cultural.

e por meio de preposições

ex.

Com isso, ele passou a exportar para os outros países da Europa e dos demais continentes produtos industrializados - principalmente tecidos - fabricados em grande quantidade e a baixo custo.

Esse mercado mundial já havia sido iniciado anteriormente com a colonização do continente americano (a partir do século XVI) e depois com a colonização da Oceania e da África.

Com essas novas nações independentes, a Divisão Internacional do Trabalho se generalizou, pois agora elas podiam comercializar com qualquer país, e não mais apenas com a sua metrópole. 


\section{Algumas Considerações}

A escolha do gênero textual está relacionada com fatores linguísticos e fatores extralinguísticos. Os primeiros envolvem escolhas léxico-gramaticais que são determinadas por pelos segundos: campo, relações e modo. Logo, é importante observar as relações entre os elementos que constituem cada oração para identificação do que é nuclear e do que é periférico. Também é significativo observar as relações entre os elementos de oração para oração, pois assim é possível verificar como as relações taxonômicas são construídas a fim de manter a conexão entre os participantes. E, ainda é possível observar as sequências de atividades por meio dos processos.

A compreensão de todas essas relações contribui para a análise dos gêneros e contribui para determinação do gênero que será utilizado em uma situação, de acordo com o propósito que se deseja alcançar.

Também é necessário compreender todos os modos de representação, verbal, visual, multimodal, a fim de identificar os significados intramodais - dentro do modo semiótico - e os significados intermodais - entre os modos semióticos -, pois cada um tem o seu potencial de significação e quando são utilizados juntos constroem outros significados. 


\section{CONSIDERAÇÕES FINAIS}

No capítulo I, conceitos fundamentais, que são comuns às teorias utilizadas nesta pesquisa são retomados. Por exemplo, o conceito de linguagem como um complexo sistema semiótico, pois carrega consigo, ao mesmo tempo, três metafunções: a de representação dos eventos do mundo físico e do mundo da consciência, a de representação das relações entre participantes de um texto e entre escritor/leitor, falante/ouvinte ou ilustrador, fotógrafo/apreciador; e a de organização das informações para essas representações.

Outro fator importante é o de que todo texto é produzido dentro de uma situação que o exige - contexto de situação - e dentro de uma cultura - contexto de cultura. Logo, com base nessa perspectiva, ao analisar ou ao produzir um texto, deve-se considerar esses contextos a fim de compreender ou definir as escolhas do gênero e as escolhas léxico-gramaticais.

No capítulo II, o desenho metodológico da pesquisa foi apresentado. Por ser uma pesquisa que envolve questões relativas à aprendizagem, em que estão envolvidos professores, alunos e avaliadores, trata-se de uma pesquisa social com abordagem qualitativa. E com base no tipo de dados que foram utilizados, documentos, concluiu-se o delineamento: em relação aos objetivos, a pesquisa é descritiva; e, em relação aos procedimentos, é documental. Ainda nesse capítulo, foi apresentado o corpora, constituído por três capítulos retirados de três livros didáticos de Geografia, adotados para os alunos de nono ano do Ensino Fundamental e também foi apresentada uma descrição geral dele.

No capítulo III são apresentadas as descrições, bem como as análises do corpora. Assim, para auxiliar nas reflexões acerca do que foi encontrado nesta pesquisa, as questões que a nortearam são retomadas.

1. Quais os gêneros presentes nos livros didáticos de Geografia?

2. Quais os propósitos sociais dos gêneros presentes nos livros didáticos de Geografia?

3. Como as características léxico-gramaticais são organizadas para representação dos eventos e das relações?

4. Quantos modos semióticos, além do verbal, compõem o livro didático de Geografia?

5. Como a relação entre os modos semióticos constroem os significados? 
Para responder às duas primeiras questões de pesquisa, foi estabelecido como objetivo identificar os gêneros presentes nos livros didáticos de Geografia, com base na perspectiva do estudo de Gêneros da Escola de Sydney, e quais os propósitos desses gêneros. E foram encontrados, nos três livros didáticos, os gêneros da família das Explicações, cujo propósito é apresentar as relações causais e consequenciais que estão envolvidas em uma sequência de eventos.

Segundo essa perspectiva, as explicações são classificadas em quatro tipos: explicação sequencial, em que um evento provoca outro, logo o evento antecedente é sempre a causa do evento consequente; explicação fatorial, que apresentam diversos fatores que culminam em uma consequência; explicação consequencial, que se trata das diversas consequências resultantes de um evento, e explicação condicional, que apresenta sequência de atividades, mas algumas consequências são obrigatórias e outras dependem de algum evento anterior. E, nos capítulos estudados foram encontradas as três primeiras, que puderam ser determinadas com base na identificação das relações causais/ consequenciais e explicativas representadas linguisticamente por meio de conjunções como porque, pois; mas também por meio de processos e de nominalizações.

Assim, como é feito há décadas na Austrália, onde há uma política de ensino intervencionista, é necessário que os alunos brasileiros sejam ensinados a compreender os propósitos sociais dos gêneros, bem como as características linguísticas que diferem um gênero de outro. Por exemplo, a linha que separa o gênero relato histórico de explicação histórica é muito tênue, pois os dois são gêneros escritos, produzidos em terceira pessoa, retratam eventos do mundo físico e envolvem participantes genéricos; e o que difere um do outro é o fato do primeiro ser sustentado por circunstâncias de tempo e o segundo, por relações de causa e consequência, passando de um relato, para uma explicação. Logo, essas relações precisam ser ensinadas, não só com objetivos escolares, mas também para contribuir com a formação de pessoas conscientes do que é possível alcançar com a linguagem.

Para responder à questão 3, os três textos foram analisados com base nas metafunções da linguagem. Assim, os eventos representados pelos processos, pelos participantes e pelas circunstâncias foram analisados com base na metafunção ideacional, e as relações lexicais também foram observadas a fim de identificar como a variável campo, do contexto de situação, foi representada em cada texto. 
As análises das relações lexicais permitiram identificar de que forma as informações dos textos foram tecidas dentro das orações e de oração para oração. E os recursos mais utilizados foram a repetição de elementos e sinonímia que, de acordo com Martin e Rose (2007), são os recursos mais comuns para mantes as ideias coesas.

Normalmente os eventos do mundo físico são construídos por meio dos processos e dos participantes envolvidos nesses processos. Segundo Halliday e Matthiessem (2014), essa é a forma congruente, isto é, a forma esperada de representação dos eventos. Contudo, uma ocorrência relevante nos três capítulos investigados foi a quantidade de metáforas gramaticais encontradas, especialmente as nominalizações, que são formas incongruentes, não esperadas, de expressar os eventos.

De acordo com Halliday e Matthiessen (2004), as crianças, ao amadurecerem cognitivamente e desenvolverem mecanismos linguísticos que significam o mundo em outros ordenamentos, não abandonam a gramática natural, nem deixam de construir orações em detrimento das construções nominais. Elas apenas vão agregando modos diferentes de significar o mundo. Logo, ao selecionar textos para serem trabalhados em sala de aula, devese avaliar se a linguagem é adequada ao nível cognitivo dos alunos. E, caso não seja, devido à linguagem técnica, o estudo do texto deve ser pensado de modo que seja explorado coletivamente, desempacotando todas as informações que estão condensadas em nominalizações, buscando, com isso, encontrar os sujeitos envolvidos em cada uma das ações, para que, assim, o texto possa atingir ao seu propósito. Pois se textos com tantas ocorrências de densidades lexicais não são esmiuçados, provavelmente, não haverá compreensão, e aprendizagem ficará comprometida.

As categorias de análise da metafunção pessoal permitiram identificar que os três textos, cujo propósito social é explicar eventos, apresentam tipicidade linguística quando a maioria das orações encontra-se na forma declarativa, revelando a relação predominante entre autores e leitores, em que aqueles, os especialistas, oferecem informações a estes (alunos). Porém, de acordo com Halliday e Matthiessen (2014), as orações também podem demandar informações, e é isso que se verifica quando os autores fazem perguntas direcionadas ao leitor; e também podem demandar serviços, o que se observa quando os autores apresentam comandos por meio do modo imperativo.

Para responder às questões 4 e 5 , foram descritos os modos como as informações são organizadas nos três capítulos. Os significados são construídos por meio de vários recursos 
como fontes coloridas, negrito, itálico, textos verbais, fotografias, mapas. Quanto ao modo verbal, foi utilizada a variedade formal da língua e, predominantemente, a terceira pessoa do discurso. Os temas mais recorrentes foram globalização, Divisão Internacional do Trabalho, países, cidades e outros sujeitos relacionados ao tema globalização. Porém, como se trata de explicações, há bastante articulação entre as ideias dos textos, por meio de elementos coesivos, como e, mas, além disso, logo há muitos temas textuais.

Às vezes, por se tratar de título de capítulo ou seção, e em outros casos, por se tratar de expressões que são inseridas pela primeira vez no texto, esses elementos recebem destaque por meio de marcação em negrito. Portanto é relevante que o professor oriente o aluno a observar essas marcações, pois auxiliam na identificação das informações mais importantes do texto, bem como na construção de uma taxonomia das informações.

Quanto aos outros modos semióticos, foram encontrados fotografias, ilustrações, pequenos ícones, mapas, quadro, seções laterais, cores diversas. Segundo Lemke (1998), Martinec e Salway (2005), Kress (2003) e Unsworth (2006), cada vez mais os textos verbais e as imagens estão sendo utilizados juntos, fato observado nos três capítulos. E, cada modo, verbal e visual, precisa ser compreendido individualmente - análise intramodal - e conjuntamente, pois não se trata de ilustrações, mas de representação dos significados utilizando o potencial de significação de cada modo semiótico, e de que juntos eles podem criar relações de concordância ou de complementariedade.

Assim, considerando todos os aspectos que podem ser observados em um texto multimodal ou em uma imagem, e o quanto são relevantes as informações contidas em todas as modalidades semióticas, é muito importante que os professores de todos os componentes curriculares conheçam as categorias de descrição e análise propostas pela Gramática do Design Visual, para que juntamente com seus alunos possam ler e compreender, não apenas os textos constituídos por linguagem verbal, mas também aqueles construídos com outros modos semióticos, pois a comunicação, cada vez mais, é constituída por elementos mais visuais, e ensinar a observar esses outros modos semióticos e a entender como eles foram construídos e o que significam é capacitar o aluno para ler o mundo.

Ao final deste estudo, pode-se afirmar que os três capítulos dos livros analisados, de um modo geral, são semelhantes, pois têm o mesmo propósito - explicar os eventos -, logo, as informações giram em torno do fator ou dos fatores que desencadearam um ou mais eventos. Também são semelhantes em relação ao campo e às relações, porque a maioria das 
informações é declarativa, os temas são ideacionais, porém com diversas ocorrências de temas textuais, o que evidencia uma articulação entre as ideias, haja vista o fato de serem explicações; apesar de o livro 1 manter o foco nas invenções que culminaram na globalização; o livro 2, nas cidades e nas consequências de um desenvolvimento desorganizado, sem estrutura para atender a todos os habitantes; e o livro 3, em todos os acontecimentos, séculos atrás, que conduziram ao surgimento da globalização, assim como as mudanças provocadas por ela.

Quanto ao modo, as informações foram organizadas de forma diferente, visto que no livro 1 as informações foram organizadas por meio de textos, de seções laterais e de fotografias; no livro 2, por meio de textos, de mapas e de seções laterais; e no livro 3, por meio de textos, de mapa, de ilustração e de fotografias. Isso demonstra algumas das possibilidades que o produtor de um texto tem para representação dos significados e essas escolhas estão relacionadas, segundo Martin e Rose (2008), à construção das informações adequando-as aos interesses de quem conta e de quem explica.

Os Parâmetros Curriculares Nacionais preconizam que o ensino de Língua Portuguesa deve ser desenvolvido por meio do estudo dos gêneros, que contribuem para a formação da proficiência do aluno em diversas situações de leitura e escrita; porém o ensino nas outras disciplinas também deve evidenciar o conhecimento dos gêneros, visto que cada área opera com conceitos, categorias e procedimentos cujos significados se concretizam pelos gêneros textuais para realizar propósitos sociais diferentes. 


\section{REFERÊNCIAS}

BAUMAN, Z. Globalização: as consequências humanas / Zygmunt Bauman; tradução Marcus Penchel. — Rio de Janeiro: Jorge Zahar Ed., 1999.

BAUER, M.; GASKELL, G. Pesquisa qualitativa com texto, imagem e som: um manual prático. Petrópolis: Vozes, 2002.

BRASIL. Parâmetros Curriculares Nacionais: $3^{\circ}$ e $4^{\circ}$ ciclos do Ensino Fundamental: Língua Portuguesa. Brasília/DF: MEC/SEF, 1998.

BRASIL. Parâmetros Curriculares Nacionais: $3^{\circ}$ e $4^{\circ}$ ciclos do Ensino Fundamental: Geografia. Brasília/DF: MEC/SEF, 1998.

CHRISTIE, F.; MARTIN, J. R. Language, Knowledge and Pedagogy: Functional Linguistic and Sociological Perspectives. London: Continuum, 2007.

CRESWELL, John W. Investigação qualitativa e projeto de pesquisa: escolhendo entre cinco abordagens/ John W. Creswell; Porto Alegre: Penso, 2014.

DENZIN, N. K.; LINCOLN, Y. S. Planejamento da pesquisa qualitativa: teorias e abordagens. Porto Alegre: Artmed, 2006.

FAIRCLOUGH, N. Analysing discourse: textual analysis for social research. London: Routledge, 2003a.

FLICK, U. Introdução à Metodologia de Pesquisa: um guia para iniciantes/ Uwe Flick; Porto Alegre: Penso, 2003.

FUZER, C.; CABRAL, S. R. S. Introdução à gramática sistêmico-funcional em língua portuguesa. Campinas, SP: Mercado das Letras, 2014.

HALliDAY, M. A. K. Language as a Social Semiotic: The Social Interpretation of Language and Meaning. London: Edward Arnold, 1978.

HALLIDAY, M.A.K.; HASAN, R.: Language, Context, and Text: Aspects of Language in a Social-Semiotic Perspective. Geelong, Vic: Deakin University Press.Oxford: OUP.(2nd edn), 1989.

HALLIDAY, M. A. K. The Language of Science. London. Continuum. 2004. 
HALliDAY, M. A. K.; MARTIN, J. R. Writing Science: Literacy and Discursive Power. London: Falmer (Critical Perspectives on Literacy and Education), 1993.

HALliDAY, M. A. K.; MATTHIESSEN, C. M. I. M. An Introduction to Functional Grammar. London: Hodder Arnold, 2014.

JEWITT, C. The Routledge handbook of multimodal analysis. London: Routledge, 2009. KRESS, G.; VAN LEEUWEN, T. Reading Images: the grammar of visual design. London: Routledge, 2006.

KRESS, G. What is Mode? Carey, J. (ed.) The Routledge Handbook of Multimodal Analysis. New York: Routledge, p. 54-67, 2009.

LEMKE, J. L. Multiplying Meaning: Visual and Verbal Semiotics in Scientific Text. In J. R. Martin \& R. Veel (Eds.), Reading Science. London: Routledge, p. 87-113, 1998.

MARTIN, J.R; ROSE, D MARTIN, J.R. e ROSE, D. Working with discourse: meaning beyond the clause.London: Continuum, 2007.

MARTIN, J.R; ROSE, D. Genre Relations: mapping culture. London: Equinox, 2008.

MARTIN, J.R; ROSE, D. Learning to Write, Reading to Learn: Genre, Knowledge and Pedagogy in the Sydney School. London: Equinox, 2012.

MARTINEC, R.; SALWAY, A. A system for image-text relation in new (and old) media. Visual Communication, New York, v. 4, n. 3, p. 337-71, 2005.

MUNIZ DA SILVA, E.C. Letramentos e Gêneros do Discurso no Ensino Fundamental. Coleção: Linguagem \& Sociedade Vol. 12 Campinas, SP: Pontes Editores, p. 207-229, 2015. OLIVEIRA, A. et al. Crise da Geografia, da escola e da sociedade. São Paulo: Contexto, 1994.

ROSE, D. Analysing pedagogic discourse: an approach from genre and register Functional Linguistics, 1:13, 2014.

ROSE, D. Genre, knowledge and pedagogy in the 'Sydne School' Artemeva, N \&AFreedma (Eds.), 2015.

ROSE, D.. New developments in genre-based literacy pedagogy. In C A MacArthur, S Graham, J Fitzgerald (eds.) Handbook of Writing Research, 2nd Edition. New York: Guildford, 227- 242, 2015. 
UNSWORTH, L. Researching Language in Schools and Communities: functional linguistics approaches. London: Cassell. 2000.

UNSWORTH, L. Towards a metalanguage for Multiliteracies Education: Describing the meaning making resources of language-image interaction. Austrália. Volume 5, número 1, p. 55-76. 2006.

VAN LEEUWEN, T.Introducing Social Semiotics: An Introductory Textbook. London: Routledge. 2005

VIEIRA , J. Antunes ; SILVESTRE, C . Introdução à Multimodalidade: Contribuições da Gramática Sistêmico-Funcional, Análise de Discurso Crítica e Semiótica Social. 01. ed. Brasília/DF: JAV. Edit, 2015.

WIGNELL,P., MARTIN, J. e Eggins, S. The discourse of geography: Ordering and explaining the experiential world' in M.A.K.Halliday and J.Martin Writing Science London: Falmer Press, 1993. 